CAROLINE CRISTIANO REAL

\title{
EFEITOS DO EXERCICIO FÍSICO SOBRE A EXPRESSÃO DE RECEPTORES DE GLUTAMATO NO ENCÉFALO DE RATOS
}

Dissertação apresentada ao Programa de PósGraduação em Fisiologia Humana do Instituto de Ciências Biomédicas da Universidade de São Paulo, para obtenção do Título de Mestre em Ciências.

São Paulo 
CAROLINE CRISTIANO REAL

\section{EFEITOS DO EXERCICIO FÍSICO SOBRE A EXPRESSÃO DE RECEPTORES DE GLUTAMATO NO ENCÉFALO DE RATOS}

Dissertação apresentada ao Programa de PósGraduação em Fisiologia Humana do Instituto de Ciências Biomédicas da Universidade de São Paulo, para obtenção do Título de Mestre em Ciências.

Área de Concentração: Fisiologia Humana

Orientador: Prof. Dr. Luiz Roberto Giorgetti de Britto

São Paulo 
DADOS DE CATALOGAÇÃO NA PUBLICAÇÃO (CIP)

Serviço de Biblioteca e Informação Biomédica do

Instituto de Ciências Biomédicas da Universidade de São Paulo

(ㄷ) reprodução total

Real, Caroline Cristiano.

Efeitos do exercício físico sobre a expressão de receptores de glutamato no encéfalo de ratos / Caroline Cristiano Real. -- São Paulo, 2009.

Orientador: Luiz Roberto Giorgetti de Britto.

Dissertação (Mestrado) - Universidade de São Paulo. Instituto de Ciências Biomédicas. Departamento de Fisiologia e Biofísica. Área de concentração: Fisiologia Humana. Linha de pesquisa: Comunicação celular no sistema nervoso.

Versão do título para o inglês: Effects of physical exercise on the glutamate receptors expression on the rat brain.

Descritores: 1. Exercício físico 2. Receptores do tipo AMPA Áreas motoras 4. Plasticidade 5. Glutamato 6. I. Britto, Luiz Roberto Giorgetti de II. Universidade de São Paulo. Programa de PósGraduação em Fisiologia e Biofísica III. Título. 


\section{UNIVERSIDADE DE SÃO PAULO \\ INSTITUTO DE CIÊNCIAS BIOMÉDICAS}

Candidato(a): Caroline Cristiano Real.

Título da Dissertação: $\quad$ Efeitos do exercício físico sobre a expressão de receptores

de glutamato no encéfalo de ratos .

Orientador(a): $\quad$ Luiz Roberto Giorgetti de Britto.

A Comissão Julgadora dos trabalhos de Defesa da Dissertação de Mestrado, em sessão pública realizada a
( ) Aprovado(a)
( ) Reprovado(a)

Examinador(a): Assinatura:

Nome:

Instituição:

Examinador(a): Assinatura:

Nome:

Instituição:

Presidente: Assinatura:

Nome:

Instituição: 


\section{Certificado}

Certificamos que o protocolo registrado sob $n^{\circ} \mathbf{7 2}$ nas fls. 47 do livro 2 para uso de animais em experimentação, sob a responsabilidade de Luiz Roberto Giorgetti de Britto Coordenador(a) da Linha de pesquiša "Efeitos do exercício físico sobre a expressão de receptores de glutamato no encéfalo de ratos" do qual participou(aram) o(s) alunos Caroline Cristiano Real e a pesquisadora Raquel Simoni Pires, está de acordo com os Principios Éticos de Experimentação Animal adotado pelo Colégio Brasileiro de Experimentação Animal (COBEA) e foi aprovado pela COMISSÃO DE ÉTICA EM EXPERIMENTAÇÃO ANIMAL (CEEA) em 31.08.2007.

São Paulo, 03 de setembro de 2007.

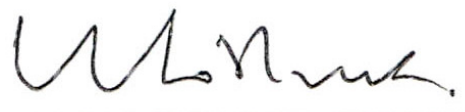

Prof. Dr. Wothan TAVARES DE Lima Coordenador CEEA - ICB/USP

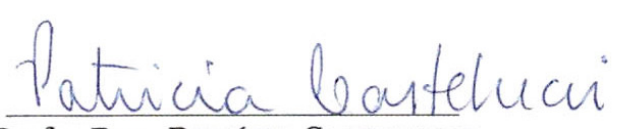

Profa. Dra. PATRÍCIA CASTELUCCI Secretária CEEA - ICB/USP 
Aos meus pais, Antônio Roberto e Ivanir, por permitirem a minha formação, meus exemplos de vida.

Ao meu irmão, Willian, exemplo de ousadia e determinação.

Ao meu namorado, Rodrigo, pelo apoio e incentivo. 


\section{AGRADECIMENTOS}

Nesta etapa do trabalho pude perceber que estava próxima de concluir mais uma fase da vida e de minha carreira acadêmica, assim, é com muita alegria que agradeço a todos que fizeram e fazem parte desta caminhada.

A Deus, pois tenho certeza que esteve o tempo todo ao meu lado me consolando e me guiando.

Ao meu orientador, Profo ${ }^{-}$Dr. Luiz Roberto Giorgetti de Britto, pela acolhida em seu laboratório, por seus ensinamentos e pela disponibilidade em me ajudar e me tranqüilizar em momentos difíceis.

À Prof ${ }^{a}$ Dra. Raquel Simoni Pires pela minha introdução à pesquisa e pela amizade sincera e verdadeira.

À Prof ${ }^{a}$ Dra. Andréa da Silva Torrão pela utilização de seu laboratório, o que possibilitou a realização de grande parte dos experimentos de immunoblotting, e pelas valiosas sugestões durante o exame de qualificação.

À Prof ${ }^{a}$ Dra. Rosana Macher Teodori pelos conselhos e contribuições para finalização deste trabalho.

À Marina, pela colaboração que iniciamos e pelas palavras amigas.

Ao técnico do laboratório Adilson Alves, pela alegria e auxílio na realização dos experimentos.

Ao Daniel, por me socorrer sempre quando resolvia fazer várias coisas ao mesmo tempo e entrava em desespero.

À Ana pelo protocolo de exercício físico e pelos experimentos que realizamos juntas.

Ao Mauro, pela alegria e pela ajuda dada em minha aula de qualificação.

Á Pós-doutoranda Rosana Pagano e aos professores Alexandre Kihara e Marucia Chacur pelas palavras de ânimo, orientações e conselhos.

Ao Richardt, pela ajuda na dosagem de corticosterona.

À Pâmella pela ajuda nos experimentos e companhia na longa viagem de volta para casa.

À Dra. Rhowena Matos, pelos ensinamentos no laboratório e de vida.

A todos os colegas de laboratório Angélica, Caroline, Danielle, Érika, Guilherme, Julian, Milena, Priscila, Rafaela, Taís, Vera, Vivian, e do laboratório vizinho, Caio, Gabriella, Luciana, Monalisa, Taísa (companheira de volta a casa).

À Prof ${ }^{a}$ Carla e sua técnica Teca, por pelas revelações de immunoblotting, à Prof $^{a}$ Dra. Silvana Bordin por disponibilizar o espectrofotômetro e à técnica do laboratório de Neuroanatomia, Ana Maria Peraçoli Campos, pelo carinho, amizade e pelo auxilio quanto à realização dos experimentos de imuno-histoquímica.

Aos funcionários do Departamento de Fisiologia e Biofísica, pela disponibilidade quanto ao esclarecimento de dúvidas.

À minha família, pela força e coragem, pelo apoio nos momentos de alegria e de dificuldade.

Ao meu namorado, Rodrigo, por não permitir que eu desistisse, por estar sempre ao meu lado me incentivando e encorajando de que eu sou e seria capaz. Além de ser um exemplo de coragem e confiança.

Aos animais os quais propiciaram o desenvolvimento desta pesquisa.

À FAPESP e CNPQ, pelo auxílio financeiro.

Muito Obrigada!!!!! 


\section{RESUMO}

Real, CC. Efeitos do Exercício Físico sobre a Expressão de Receptores de Glutamato no Encéfalo de Ratos. [Dissertação] São Paulo: Instituto de Ciências Biomédicas da Universidade de São Paulo; 2009.

O exercício físico crônico traz inúmeros benefícios para o sistema nervoso central (SNC), pois promove a melhora da memória e cognição, aumento da plasticidade e aprendizado, além de um efeito protetor em relação ao declínio mental decorrente do envelhecimento e de lesões do SNC. Porém, poucos estudos analisam o efeito do exercício a curto prazo. Este estudo visou observar os efeitos plásticos induzidos pelo exercício a curto prazo em regiões do cerebelo, hipocampo, córtex motor e estriado de ratos. A avaliação foi feita por meio da expressão de subunidades dos receptores de glutamato do tipo AMPA (GluR1, GluR2/3). Utilizaram-se ratos Wistar adultos, que foram divididos em 3 grupos experimentais com diferentes tempos de corrida: 3 dias (COR3), 7 dias (COR7) e 15 dias (COR15); e um grupo controle (CONT). Os animais experimentais foram submetidos ao protocolo de exercício físico leve/moderado em esteira (KT 3000 - IMBRAMED) a uma velocidade de $0,6 \mathrm{Km} / \mathrm{h}$ por 40 minutos, percorrendo aproximadamente $395 \mathrm{~m} / \mathrm{dia}$. Após o treino, os encéfalos foram submetidos às técnicas de imuno-histoquímica e immunoblotting, foi realizada ainda, a dosagem de corticosterona plasmática por ELISA. Analisou-se a densidade óptica das bandas resultadas do immunoblotting os quais foram submetidos à análise estatística utilizando o teste ANOVA e o pós-teste de Bonferroni, quando apropriado. Adotou-se nível de significância de 5\%. A expressão das subunidades GluR1 e GluR2/3 apresentaram mudanças distintas nas estruturas analisadas após o exercício físico, tanto na imuno-histoquímica quanto no immunoblotting. No cerebelo, houve um decréscimo não significativo em COR3 (17\%), seguido de acréscimo não significativo em COR7 (23\%), voltando à expressão do CONT em COR15. No hipocampo houve uma queda significativa na expressão de GluR1 em COR3 (40\%) em relação ao CONT, retornando aos níveis basais em COR7, podendo ser explicado pelo aumento encontrado nos níveis do hormônio corticosterona no plasma em COR3. No córtex cerebral observou-se uma queda da expressão de GluR1, com máxima queda em COR7 (52\%), retornando à expressão basal em COR15. O estriado não sofreu alterações na expressão de GluR1 ao longo dos primeiros 7 dias, tendo um aumento significativo em COR15 (90\%). A expressão de GluR2/3 não foi alterada em relação ao CONT, exceto no cerebelo, onde houve um decréscimo significativo em dois momentos distintos, COR3 (55\%) e COR15 (25\%), retornando à expressão basal em COR7. Os nossos dados revelam que o exercício físico a curto prazo foi capaz de promover alterações plásticas ao longo do treinamento de forma distinta nas estruturas e subunidades dos GluRs estudadas, sugerindo uma participação específica desses receptores em cada estrutura e tempo de treino. Estas mudanças, por sua vez, podem promover alterações na resposta motora que se desenvolve pelo treinamento.

Palavras-Chave: Exercício Físico; Receptores do tipo AMPA; Áreas motoras; Plasticidade; Glutamato; 


\begin{abstract}
REAL, CC. Effects of physical exercise on the glutamate receptors expression on the rat brain. [Dissertation] São Paulo: Instituto de Ciências Biomédicas da Universidade de São Paulo; 2009.

Chronic physical exercise can promote many benefits for the central nervous system (CNS). For instance, exercise can improve memory and cognition, increase plasticity and learning, in addition to the protective effect on the mental decline that ensues with aging and after CNS injuries. However, little is known about the short-term effects of exercise. This study aimed at analyzing the plastic effects of the short-term exercise upon the rat cerebellum, hippocampus, motor cortex, and striatum. This assessment was made by verifying the expression of AMPA - type glutamate receptor subunits (GluR1 and GluR2/3). We used Wistar adults rats, divided into 3 experimental groups based on duration of exercise: 3 days (COR3), 7 days (COR7), and 15 days (COR15); and a control group (CONT). The experimental animals were subjected to a light/moderate treadmill exercise protocol (KT 3000 - IMBRAMED) at speed of the $0.6 \mathrm{Km} / \mathrm{h}$ for 40 minutes, so that the rats run approximately $395 \mathrm{~m} /$ day. After training, the brains were subjected to the techniques of immunohistochemistry and immunoblotting, and the plasma corticosterone was measured by ELISA. We analyzed the optical density of resulting bands, and the data were statistically analyzed with an ANOVA test and the post-hoc Bonferroni test. Immunohistochemical material was subjectively analyzed. The significance level used was $5 \%$. The GluR1 and GluR2/3 subunit expression showed distinct changes in the structures analyzed after physical exercise both for immunohistochemistry and immunoblotting. In the cerebellum, there was no statistically significant changes, with some tendency of a decrease for COR3 (17\%), followed by a tendency of an increase for COR7 (23\%). In the hippocampus, there was a significant decrease of the GluR1 expression for COR3 (40\%) when compared to CONT, whereas the expression was similar to controls for COR7. In the cerebral cortex there was a drop of GluR1 expression for COR3, with COR7 exhibiting the largest drop (52\%), apparently returning to the basal expression for COR15. In the striatum, there was no change of GluR1 expression during the first seven days, with a significant increase for COR15 (90\%). The GluR2/3 expression did not change in any brain structure analyzed, except in the cerebellum, where there was a significant decrease for two distinct groups, COR3 (55\%) and COR15 (25\%). Our data show that short-term physical exercise was able to promote plastic changes during training. The changes were different for the structures and GluR subunits analyzed, and thus we can suggest a specific involvement of these receptors for each structure and training time. These changes, in turn, can promote changes in the motor response which is improved by training.
\end{abstract}

Keywords: Physical exercise; AMPA receptors subunits; Motor areas; Plasticity; Glutamate. 


\section{SUMÁRIO}

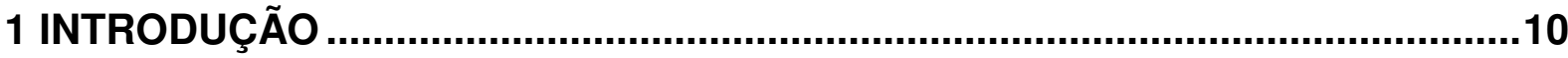

1.1 Exercício ................................................................................................. 10

1.2 Neurotransmissão Glutamatérgica ........................................................13

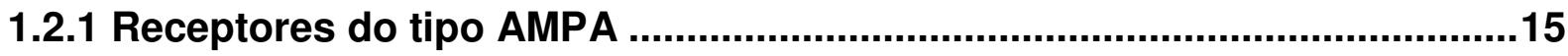

1.2.2 Receptores do tipo NMDA .......................................................................17

1.3 Caracterização Anátomo-Funcional .............................................................19

1.3.1 Caracterização Anátomo-Funcional do Cerebelo........................................19

1.3.2 Caracterização Anátomo-Funcional do Hipocampo.....................................24

1.3.3 Caracterização Anátomo-Funcional do Córtex Motor..............................32

1.3.4 Caracterização Anátomo-Funcional do Estriado....................................35

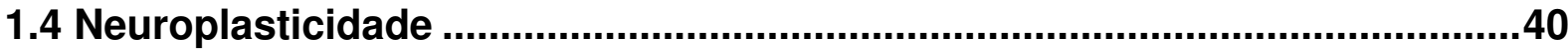

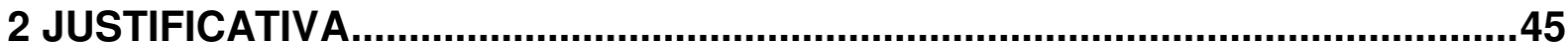

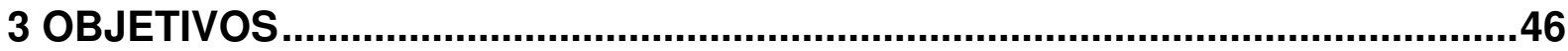

4 MATERIAL E MÉTODOS .............................................................................47

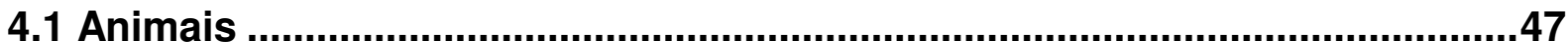

4.2 Protocolo de exercício .................................................................................47

4.3 Protocolo de imuno-histoquímica ...............................................................48

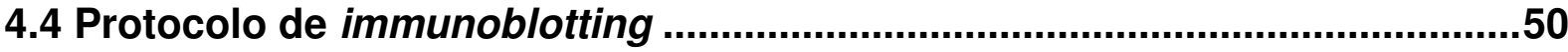

4.5 Dosagem de Corticosterona no Plasma..........................................................51

4.6 Pesagem das Adrenais ...................................................................................52

4.7 Análise Estatística.......................................................................................52

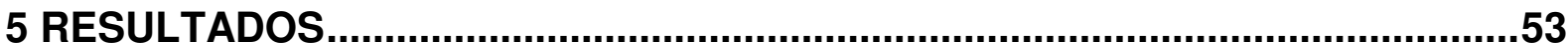

5.1 GluR1 ..................................................................................................... 54

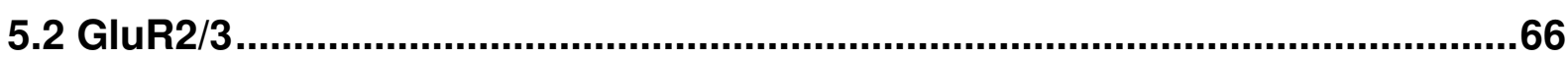

5.3 Dosagem de Corticosterona e Pesagem das Adrenais..................................75

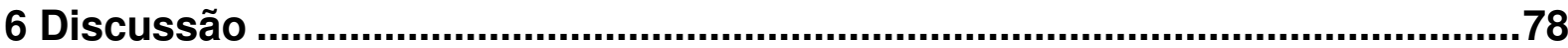

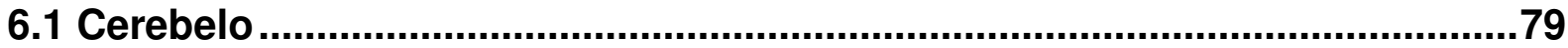

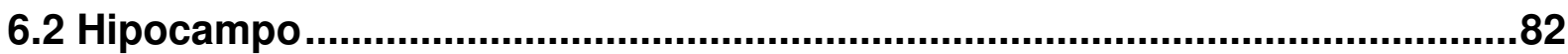

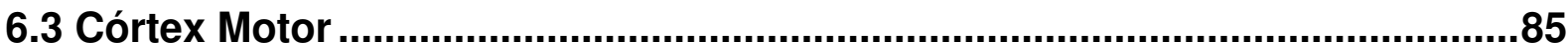

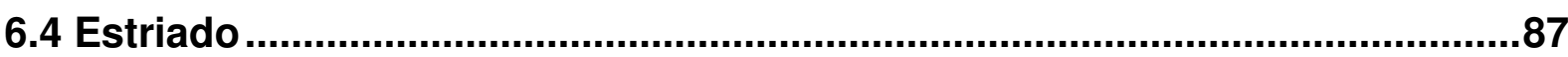

7 CONCLUSÕES ................................................................................................90

REFERÊNCIAS BIBLIOGRÁFICAS .................................................................91 


\section{INTRODUÇÃO}

\subsection{Exercício}

Os efeitos do exercício físico sobre o sistema nervoso central (SNC) são objetivo de estudos relativamente recentes. Independentemente da modalidade, exercícios são capazes de proporcionar inúmeros benefícios ao SNC de humanos (Dustman et al., 1990; Lupinacci et al., 1993; Kramer et al., 1999) e animais (GómezPinilla et al., 2002; Molteni et al., 2002; Marin et al., 2003; Vaynman et al., 2004b; Kim et al., 2004; Ying et al., 2005), além dos efeitos benéficos sobre outros sistemas, tais como o músculo-esquelético (Jeneson et al., 2007; Daussin et al., 2008; Silva et al., 2009), respiratório (Koepp e Janot, 2008) e cardiovascular (Michelini, 2007; Hua et al., 2009). São diversas as regiões estudadas, sendo os principais alvos a medula (Williams et al., 1995; Ishide et al., 2000; Reidman et al., 2000; Nauli et al., 2001a,b; Kajekar et al., 2002; Gomez-Pinilla et al., 2002; Ishide et al., 2003; Ishide et al., 2005), a substância negra do mesencéfalo (Mabandla et al., 2004), o estriado (Liste et al., 1997; Meeusen et al., 1997; Dishman, 1997; Mabandla et al., 2004; Li et al., 2005; Poulton e Muir, 2005), o giro denteado (Kim et al., 2004; Farmer et al., 2004; Uysal et al., 2005), todas as sub-regiões do hipocampo (Radak et al., 2001; Molteni et al., 2002; Berchtold et al., 2002; Holmes et al., 2004; Vaynman et al., 2004; Brechtold et al., 2005; Stranahan et al., 2007), o tálamo (Ding et al., 2002), o hipotálamo (Overton et al., 1994; Kramer et al., 2000; Andersson et al., 2005), o córtex cerebral (Gentile et al., 1987; Chu e Jones, 2000; Dietrich et al., 2005; Leggio et al., 2005; Stranahan et al., 2007) e o circuito cerebelo-tálamo-córtex (Holschneider et al., 2006). Além disso, há estudos que demonstram ação do SNC sobre a regulação do sistema nervoso simpático em relação ao treino físico (Mueller, 2007; Mattson e Wan, 2008).

Há estudos que comprovam melhoras na performance do aprendizado cognitivo e motor (Van Praag, et al., 1999b; Hanna e Fins, 2006). Foi observado também um efeito protetor, atenuando o declínio mental decorrente do 
envelhecimento (Mattson et al., 2000; Larsen et al., 2000; Laurin et al., 2001; Carro et al., 2001; Wang et al., 2001; Tillerson et al., 2003; Kronenberg et al., 2006; Sumic et al., 2007). Sumic et al. (2007) demonstraram que idosos de ambos os sexos que realizaram atividade física pelo menos 4 horas/semana ao longo da vida tiveram menores diminuíram déficits cognitivos quando comparados a sedentários. A prática de exercício em roda por camundongos dos 3 aos 9 meses de idade revelou um menor declínio da neurogênese comum em animais adultos (Kronenberg et al., 2006). Tillerson et al. (2003) demonstraram que ratos e camundongos submetidos ao exercício em esteira 2x/dia logo após a injeção de drogas que geram o modelo de Parkinson apresentaram diminuição ou até mesmo ausência de déficits motores, sugerindo que o exercício foi capaz de gerar efeitos neuroprotetores. O exercício tem se mostrado capaz também de aumentar a resistência a lesões do SNC (Gentile et al., 1987; Stummer et al., 1994; Wang et al., 2001; Cotman e Berchtold, 2002; Chen et al., 2007), facilitando a recuperação funcional pós-lesão (Grealy et al., 1999; Grealy et al., 1999; Edgerton et al., 2004; Lacerda et al., 2007), revertendo quadros de inibição da proliferação celular no hipocampo provocados pelo etanol (Crews et al., 2004; Redila et al., 2006) e outras situações como a doença de Huntington (Kohl et al., 2007) e esclerose múltipla (Benedetti et al., 2009).

Além disso, o exercício é capaz de promover plasticidade neural (Neeper et al., 1997; Molteni et al., 2002; Vaynman et al., 2004b; Molteni et al., 2004b; Lambert et al., 2005), como, ativação da atividade de células neurais (Czuro et al., 1999; Liepert et al., 2004), e promover neurogênese (Van Praag, et al., 1999a; Kempermann et al., 2000; Kim et al., 2004; Eadie et al., 2005; Naylor et al., 2005; Olson et al., 2006). Trabalhos recentes revelaram alterações na expressão de genes envolvidos na plasticidade sináptica (Molteni et al., 2002; Cotman e Engesser-Cesar, 2002; Farmer et al., 2004; Dishman et al., 2006), os quais parecem ser responsáveis por alterações no número, estrutura e função dos neurônios (Van Praag et al., 1999; Ang et al., 2006), além de alterações na expressão de genes de resposta imediata como c-fos, por exemplo (Liste et al., 1997). Estudos atuais deram início a uma sequência de pesquisas que avaliam o envolvimento das sinapsinas (Gómez-Pinilla et al., 2002; Vaynman et al., 2003; Vaynman et al., 2004a,b; Griesbach et al., 2004a,b; Molteni et al., 2004a; Ying et al., 2005) e sinaptofisinas (Ding et al., 2002; 
Marin et al., 2003; Lambert et al., 2005;) na plasticidade do SNC decorrente do exercício físico.

Os efeitos do exercício no sistema glutamatérgico são pesquisados desde 1955 (Vrba, 1955). Estudos revelaram um decréscimo na concentração de glutamato livre no metabolismo de ratos após atividade física (Vrba, 1955; Henriksson J., 1991; Santos et al., 2007); por outro lado, Bland et al. (1999) observaram um aumento na liberação do neurotransmissor no hipocampo, estriado e córtex sensório-motor de ratos após movimentos. Estudo por microdiálise em ratos pós-isquemia local submetidos ao exercício em esteira demonstrou aumento na liberação do neurotransmissor no hipocampo do segundo ao sétimo dia de corrida, voltando às taxas basais com 14 dias de exercício, enquanto o animal que não realizou exercício físico só sofreu decréscimo na liberação de glutamato (Leung et al., 2006). Estudos de Dietrich et al. (2005), com camundongos, revelaram que o exercício voluntário regular é capaz de promover plasticidade sináptica como consequência do aumento da concentração do neurotransmissor na fenda sináptica, seguida pelo aumento significativo da expressão de receptores para glutamato. Os resultados obtidos através da utilização da técnica de immunoblotting no córtex cerebral de camundongos submetidos à atividade física crônica demonstraram um acréscimo de $129 \%$ na subunidade GluR1, 118\% nas subunidades GluR2/3, 150\% na subunidade NR1 fosforilada e 183\% na subunidade NR2B, além de acréscimo das proteínas responsáveis pelo ancoramento dos receptores de glutamato na membrana, como por exemplo as PDZs (Dietrich et al., 2005). Estudos buscando avaliação de mediadores como o ácido gama-aminobutírico, o óxido nítrico ou óxido nítricosintase e outros neuromediadores surgiram depois dos estudos de glutamato (Ishide et al., 2000; Chiodera al., 1993).

A determinação da duração do exercício nos estudos que avaliam seu potencial terapêutico é uma dúvida que persiste. Em seu trabalho de 2002, Molteni et al. demonstraram que existem respostas diferentes na expressão de genes após o exercício agudo e crônico, porém o fator neurotrófico derivado do encéfalo (BDNF) apresentou acréscimo em todos os tempos de exercício do estudo (3, 7 e 28 dias). A proteína dependente de cálcio/calmodulina quinase (CaM-K) é ativada durante os períodos de exercício agudo e crônico, após ocorrer aumento da transmissão glutamatérgica, enquanto MAP-K/ERK é mais ativada durante o exercício crônico. Já 
o subtipo do receptor de glutamato do tipo NMDA -NR1- apresentou pico de expressão gênica após 3 dias de corrida, sofrendo decréscimo gradativo após 7 e 28 dias. Todas estas alterações elucidam o envolvimento do exercício físico na plasticidade neural (Molteni et al., 2002). No entanto, estudos de Scopel et al. (2006) demonstraram ser o exercício de intensidade moderada o mais adequado, por reduzir desidrogenase láctica proveniente da privação de oxigênio e glicose que ocorre no encéfalo, principalmente no hipocampo, após exercício intenso, e que é capaz de provocar graves danos ao SNC (Scopel et al., 2006; Cechetti et al., 2007).

\subsection{Neurotransmissão Glutamatérgica}

Desde a década de 50, estudos estabelecem relações entre as ações excitatórias do glutamato, via ativação de seus múltiplos receptores, na transmissão sináptica no sistema nervoso central (Watkins e Jane, 2006). Os dados científicos demonstram ser o glutamato, principal neurotransmissor excitatório, e os seus receptores (GluRs) responsáveis por ativar vias que promovem as respostas a curto e longo prazo pela célula neural, vias estas que têm suas atividades intensificadas após atividade física. A neurotransmissão glutamatérgica é fundamental na transdução de sinais, memória, aprendizado, comportamento, plasticidade sináptica, formação da rede neuronal durante o desenvolvimento e outros processos (Hebb, 1949; Eccles, 1964; Mayer e Westbrook, 1987; Dingledine et al., 1988; Monaghan et al., 1989; Martin et al, 1993a; Kind e Neumann, 2001; Pires et al., 2006).

Os receptores são constituídos por proteínas transmembrânicas (Meldrum, 2000), e suas propriedades funcionais são determinadas pelos subtipos de GluRs, por modificações pós-transcripcionais do RNA mensageiro e pela composição das subunidades (Burnashev e Rozov, 2000). De acordo com os estudos farmacológicos e eletrofisiológicos, os GluRs podem ser divididos em dois grandes grupos: receptores ionotrópicos (iGluRs) e metabotrópicos (mGluRs) (Hollmann et al., 1989; Monaghan et al., 1989; Ozawa, 1998; Meldrum, 2000; Kew, 2005; Watkins e Jane, 2006). No SNC de mamíferos, os GluRs foram localizados tanto em neurônios (Mayer e Westbrook, 1987) como em células não excitáveis, como astrócitos e oligodendrócitos (Mayer e Westbrook, 1987; Klielberg et al., 1998). 
Os iGluRs são constituídos por 3 domínios transmembrânicos (M1, M3 e M4) e uma alça localizada na membrana com face citoplasmática (M2) (Meldrum, 2000), sendo esta responsável por controlar a permeabilidade do canal iônico (Kuner et al., 1996 e 1997). Estes receptores formam um composto tetramérico (Doyle et al., 1998; Laube et al., 1998) com subunidades específicas para as 3 famílias de receptores (Dingledine e Conn, 2000). Estes formam um complexo receptor homo ou heteroligomérico (Kew, 2005), específico para cátions (Ozawa, 1998; Meldrum, 2000) e são capazes de gerar respostas sinápticas rápidas (Burnashev e Rozov, 2000; Brockie, 2006). Os iGluRs são divididos em 3 subtipos, de acordo com a seletividade aos agonistas de glutamato em receptores N-metil-D-aspartato (NMDA), receptores tipo ácido $\alpha$-amino-3-hidroxi-5metil-4isoxazolpropiônico (AMPA) e receptores de cainato (KA) (Ozawa, 1998; Burnashev e Rozov, 2000; Meldrum, 2000; Kew, 2005; Watkins e Jane, 2006). Outras subunidades que vem sendo estudadas são as "órfãs”, formadas pelos genes $\delta 1$ e $\delta 2$ (Lomeli et al., 1993; Gao et al., 2007). Estas proteínas não formam canais funcionais mas são responsáveis por modificar a função de canais constituídos por outras subunidades (Kashiwabuchi et al., 1995). Os canais formados pelos receptores de glutamato apresentam respostas diferentes a um mesmo estímulo de acordo com a sua composição (Dingledine et al., 1999), e a sua maioria possibilita a entrada de cálcio, responsável por ativar enzimas intracelulares que promovem efeitos sobre o desenvolvimento e algumas formas de plasticidade sináptica, tais como aprendizado e memória (Maren e Baudry, 1995; Asztely e Gustafsson, 1996). O influxo de cálcio ocorre principalmente por subunidades do tipo NMDA, podendo assim ela participar tanto dos processos de plasticidade neural, mas também em processos degenerativos tais como, epilepsia, isquemia cerebral, ou doenças neurodegenerativas como Parkinson, Alzheimer, esclerose lateral amiotrófica e doença de Huntington (Dingledine et al., 1999). Na epilepsia, o exercício físico é capaz de promover benefícios tais como diminuição na frequência (Arida et al., 1999), na intensidade das crises (Eriksen et al., 1994) e aumento da magnitude da potenciação a longo prazo (Arida et al., 2004, Arida et al., 2008). Muitos estudos vêm sendo desenvolvidos em modelos animais de epilepsia e parkinsonismo que demonstram os efeitos neuroprotetores de medicamentos antagonistas dos receptores NMDA e AMPA, e também o efeito 
sobre a melhora da cognição com o uso de agonistas dos receptores de glutamato (Dingledine et al., 1999).

Os mGluRs são ancorados à membrana celular por sete domínios transmembrânicos, estando acoplados a proteína-G que promovem a modulação de efetores intracelulares que ativam e/ou inibem diversos eventos de transdução do sinal celular (Obrenovitch e Urenjak, 1997), através de segundos mensageiros (Meldrum, 2000). Estas respostas celulares resultam em ações diversas como o aumento da hidrólise do fosfoinositol, ativação da fosfolipase $D$, diminuição da formação de cAMP e mudança na função de canais iônicos (Monaghan et al., 1989; Schoepp et al., 1990). Desta forma, estes receptores são classificados em 3 grupos baseando-se na especificidade dos segundos mensageiros. As técnicas de biologia molecular revelaram oito subtipos de receptor metabotrópico de glutamato (Masu, et al., 1991; Nakanishi, 1992; Duvoisin et al., 1995) classificados em três subgrupos com base nas seqüências homólogas de seus aminoácidos. São eles: grupo I (mGluR1 e mGluR5), grupo II (mGluR2 e mGluR3), grupo III (mGluR4, mGluR6, mGluR7 e mGluR8) (Pin e Duvoisin, 1995).

A seguir, detalharemos os subtipos AMPA e NMDA por serem os principais responsáveis pelos processos de neuroplasticidade que envolve o sistema glutamatérgico (Genoux e Montgomery, 2007).

\subsubsection{Receptores do tipo AMPA}

Os receptores do tipo AMPA, antigamente chamados de receptores de quisqualato, podem ser formados por até quatro subunidades diferentes (GluR1GluR4) que formam canais iônicos capazes de gerar respostas mais rápidas do que os outros tipos de iGluRs. Estes receptores apresentam características funcionais que podem variar de acordo com sua constituição e arranjo protéico (Hollmann e Heinemann, 1994; Burnashev e Rozov, 2000; Tanaka, 2005). Desta forma, ao ocorrer a ligação do glutamato ao receptor do tipo AMPA ocorre o influxo de $\mathrm{Na}^{+}$, às vezes de $\mathrm{Ca}^{2+}$ e o efluxo de $\mathrm{K}^{+}$, sendo então o canal formado pelo receptor $\mathrm{o}$ principal condutor de corrente mesmo em situação de repouso (Sommer et al., 1992). O influxo de cátions monovalentes pelos canais dos receptores AMPA causa 
uma despolarização pós-sináptica transiente; já o influxo de $\mathrm{Ca}^{2+}$, pode provocar uma sinalização citoplasmática, promovendo a plasticidade sináptica e outras alterações a longo prazo. Os receptores do tipo AMPA possuem duas versões alternativas, chamadas de isoformas flip e flop (Këinanen et al., 1990), sendo que a flop dessensibiliza rapidamente (Sommer et al., 1990), além de ser menos sensível a drogas bloqueadoras (Bass, 2002).

A presença de pelo menos uma subunidade GluR2 na forma editada na constituição do canal é capaz de causar uma reduzida permeabilidade ao $\mathrm{Ca}^{2+}$, devido a presença de um aminoácido arginina carregado positivamente na região M2, ao invés de glutamina como ocorre nas outras subunidades. O DNA do gene GluR2 codifica um resíduo de glutamina na região M2 que tem seu códon substituído por uma arginina durante a edição do mRNA (Paperna et al., 1996; Meldrum, 2000; Kew, 2005). Estudos que combinaram métodos de eletrofisiologia (patch-clamp) com os de biologia molecular (reação em cadeia da polimerase- PCR) indicaram que o grau de permeabilidade ao íon $\mathrm{Ca}^{2+}$ depende da quantidade de GluR2 expresso no neurônio (Bochet et al., 1994; Jonas et al., 1994; Geiger et al., 1995) (Figura 1). A permeabilidade ao cálcio é mais abundante em células do tipo II do hipocampo e do neocórtex do cérebro de ratos (Jonas et al., 1994; Geiger et al., 1995; Isa et al., 1996; Itazawa et al., 1997), além de células não-piramidais do hipocampo e do neocórtex e neurônios do corno dorsal da medula espinal (Isa et al., 1996; Itazawa et al., 1997).

Assim, o receptor do tipo AMPA apresenta sistemas complexos e particulares envolvidos na plasticidade sináptica por ser capaz de regular o fluxo de íons na célula, principal mecanismo de regulação plástica, pois com a entrada e saída de íons ocorrem alterações intracelulares que desencadeiam respostas metabólicas, como ativação de segundos mensageiros ou até mesmo ativação do receptor de glutamato do tipo NMDA que é dependente de voltagem (Bredt e Nicoll, 2003; Malenka, 2003; Perestenko et al., 2003; Sheng e Lee, 2003). 

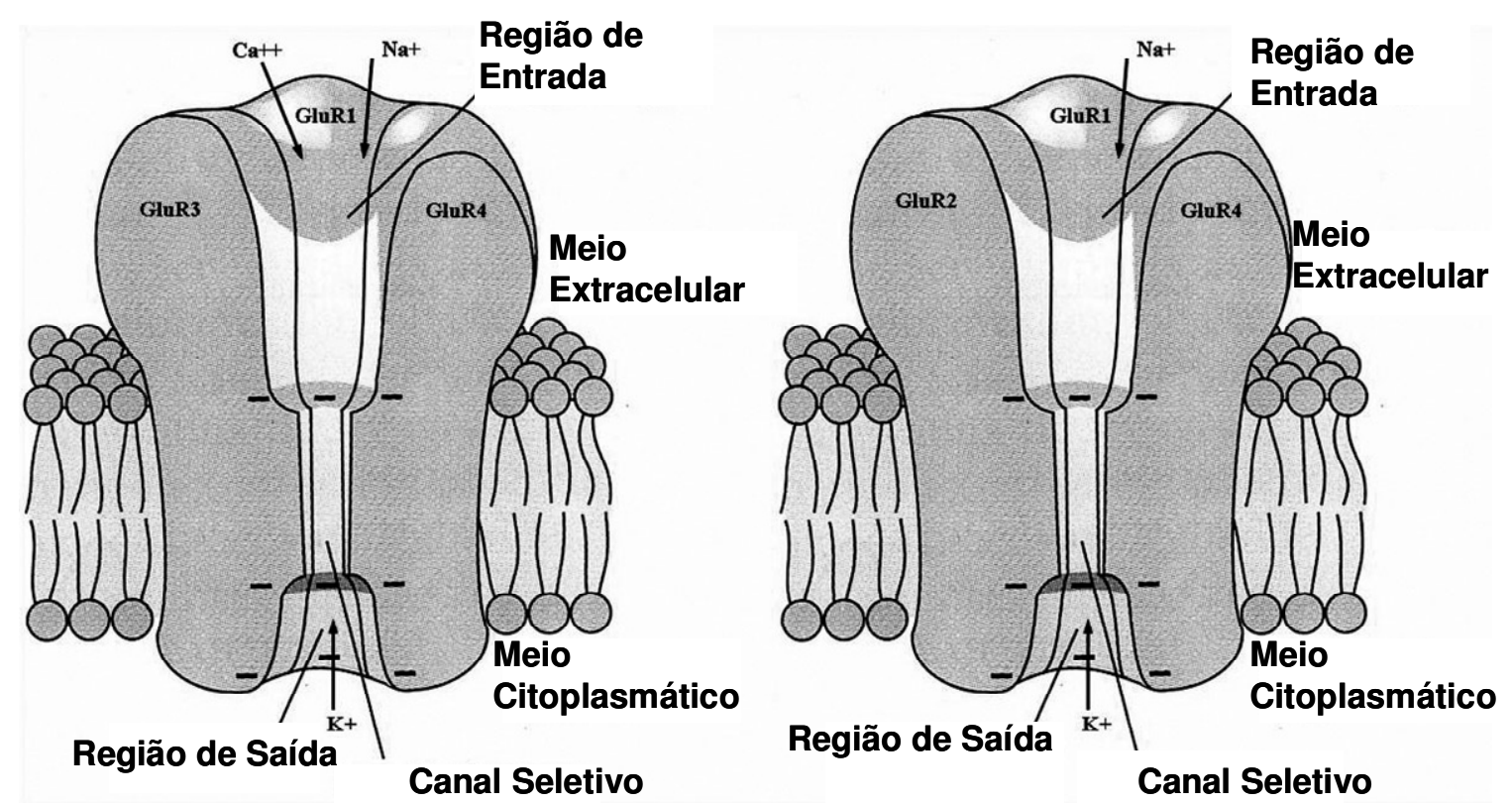

Figura 1. llustração do receptor de glutamato do tipo AMPA. Note que com a presença da subunidade GluR2 não há entrada de cálcio pelo canal. Modificado de Kandel et al (2003).

Estudos de imuno-histoquímica no cérebro de ratos mostraram que as subunidades GluR1, GluR2/3 e GluR4 são abundantes e diferencialmente distribuídas em corpos celulares e processos de neurônios no córtex cerebral, gânglios da base, tálamo, cerebelo e tronco cerebral (Petralia e Wenthold, 1992; Martin et al., 1993a), além da presença de RNA mensageiro de todas as subunidades em neurônios, células gliais e oligodendrócitos (Bergles et al., 2000).

Estudos revelaram variações na expressão das subunidades dos GluRs tipo AMPA com a idade, sugerindo uma participação deles tanto na regulação da sinaptogênese e aumento da plasticidade sináptica (Bahn et al, 1994; Franciosi, 2001; Batista et al., 2002; Pires et al., 2006;) como na neurotoxicidade (Choi, 1988; Pagliusi et al., 1994).

\subsubsection{Receptores do tipo NMDA}

Nos receptores do tipo NMDA, a subunidade NMDAR1 apresenta 7 versões alternativas, chamadas de NMDAR1A-G (Nakanishi, 1992; Mori e Mishina, 1995). Estes receptores são lentos, porém altamente permeáveis ao $\mathrm{Ca}^{2+}$, bem como a $\mathrm{Na}^{+}$ e $\mathrm{K}^{+}$, sendo que o aumento de $\mathrm{Ca}^{2+}$ intracelular pode ser responsável tanto pela 
plasticidade neuronal como pela neurotoxicidade (Monaghan et al., 1989; Kew, 2005). As outras subunidades, NMDAR2A-D, necessitam da presença da subunidade NMDAR1 (NR1) para formar um receptor funcional (Nakanishi, 1992; Mori e Mishina, 1995). Este receptor pode ser distinguido dos outros por sofrer diversas ações de agonistas, tais como glutamato, quisqualato, homocisteato e ibotenato, e também devido as suas propriedades, que incluem a modulação pela glicina, bloqueio do canal por $\mathrm{Mg}^{2+}$, ativação pela poliamina e inativação pelo $\mathrm{Zn}^{2+}$ (Peters et al., 1987; Westbrook e Mayer, 1987; Monaghan et al., 1989; Trombley e Shepherd, 1996). A inibição por $\mathrm{Zn}^{2+}$ envolve diminuição na frequência e no tempo de abertura do canal (Christine e Choi, 1990; Legendre e Westbrook, 1990). O bloqueio ou não do canal iônico pelo $\mathrm{Mg}^{2+}$ é determinado pelo resíduo de aminoácido que se localiza no sítio $Q / R / N$, sendo o resíduo "asparagine" na subunidade NR2A o mais potente no bloqueio do canal por este cátion (Wollmuth et al., 1998). A saída do $\mathrm{Mg}^{2+}$ do poro do canal é voltagem-dependente; assim, quando o receptor do tipo AMPA é ativado ocorre despolarização da membrana, e consequentemente o canal do receptor do tipo NMDA é desbloqueado, pois o $\mathrm{Mg}^{2+}$ é expelido do canal por repulsão eletrostática, permitindo então um alto fluxo de íons.

A abertura do receptor NMDA é conseqüência, assim, da despolarização da membrana celular provocada pela neurotransmissão glutamatérgica que envolve o receptor do tipo AMPA. Os receptores de NMDA por sua vez, estão relacionados com a potencialização de longo prazo (LTP) (Lampreecht e LcDoux, 2004), neuroproteção (Jayakar e Dikshit, 2004) e outros plásticos (Limatola, 2004).

Estudos empregando ligantes radioativos de receptores de NMDA demonstraram sua distribuição difusa pelo encéfalo, predominantemente no prosencéfalo (Subramaniam e McGonigle, 1991; Monaghan et al, 1989). Entre as estruturas do encéfalo, foi observada maior expressão na região CA1 do hipocampo (Monaghan et al., 1989). Com a utilização da técnica de hibridização in situ estudouse a distribuição de cada subunidade no encéfalo. O mRNA de NR1 foi encontrado praticamente em todo o encéfalo de roedores adultos, enquanto o de NR2B apresentou elevada expressão no córtex cerebral, hipocampo e cerebelo. A expressão de mRNA de NR2C foi mais acentuada nas células granulares do cerebelo e interneurônios do hipocampo e menor no bulbo olfatório e tálamo. Pequena expressão do mRNA de NR2D foi detectada no tálamo, bulbo olfatório, 
ponte e hipocampo (Monyer et al., 1994). Empregando-se a técnica de hibridização in situ, os resultados observados por Petralia et al. (1994b), corroboram as análises imuno-histoquímicas realizadas pelo mesmo grupo. Outros estudos verificaram que combinações de diferentes subunidades na composição do receptor são capazes de promover diferentes respostas. A co-expressão de NR3A com NR1 e NR2A, por exemplo, causa redução das correntes iônicas na célula como um todo (Ciabarra et al., 1995) ou na condutância do canal individualmente (Das et al., 1998). Desta forma, ocorre uma baixa permeabilidade ao $\mathrm{Ca}^{2+}$ na célula. Estes resultados sugerem que a subunidade NR3A deve ser uma importante reguladora da função dos receptores do tipo NMDA, controlando principalmente o influxo de $\mathrm{Ca}^{2+}$ pelos canais durante o potencial de ação.

\subsection{Caracterização Anátomo-Funcional}

Nos próximos tópicos serão abordadas as estruturas do SN que foram estudadas neste trabalho, permitindo um melhor entendimento de sua composição e função na atividade motora, além de situá-los quanto à neurotransmissão glutamatérgica, sendo elas o cerebelo, o hipocampo, o córtex motor e o estriado.

\subsubsection{Caracterização Anátomo-Funcional do Cerebelo}

O aprendizado de habilidades motoras pelo cerebelo, mediado por receptores de glutamato, foi descrito pela primeira vez em 1970, por David Marr e James Albus, que propuseram que as fibras trepadeiras, ao fazerem contato com as células de Purkinje, modificavam por um tempo prolongado a resposta desses neurônios aos estímulos vindos das fibras musgosas. Assim, fibras trepadeiras enfraquecem a sinapse entre a célula de Purkinje e a fibra paralela; este processo atualmente é conhecido por depressão de longo prazo (melhor descrito na seção 1.4). As fibras trepadeiras detectam diferenças entre as informações sensoriais esperadas e as que ocorreram de fato, e então alteram a força de certas sinapses entre células de Purkinje e fibras paralelas selecionando células específicas para programar e corrigir 
os movimentos motores (Kakegawa et al., 2008). Holschneider et al. (2007) demonstraram que após treino físico há uma reorganização funcional cerebral no circuito cerebelo-tálamo-cortical, mediado pelo glutamato. Notou-se aumento da atividade nos núcleos cerebelares profundos interpósito, fastigial e denteado, sem alterações nas regiões lateral e intermediária do córtex cerebelar, enquanto que houve decréscimo na atividade do verme cerebelar.

O cerebelo de mamíferos é formado por córtex cerebelar (substância cinzenta externa), substância branca interna e por núcleos cerebelares profundos, que representam suas principais estruturas de saída. Ele pode ser dividido de acordo com o desenvolvimento evolutivo ou sua funcionalidade. Funcionalmente ele é dividido em: vestibulocerebelo, espinocerebelo e cerebrocerebelo, as quais recebem aferências distintas, projetando-se para diferentes partes dos sistemas motores através dos núcleos profundos.

O córtex cerebelar é formado por três camadas distintas: molecular, das células de Purkinje e granular. A disposição celular em cada uma dessas camadas é a mesma em todos os lobos, diferindo somente na procedência das vias aferentes e no destino das vias eferentes (Delgado- Garcia, 2001; Sarna e Hawkes, 2003) (Figura 2).

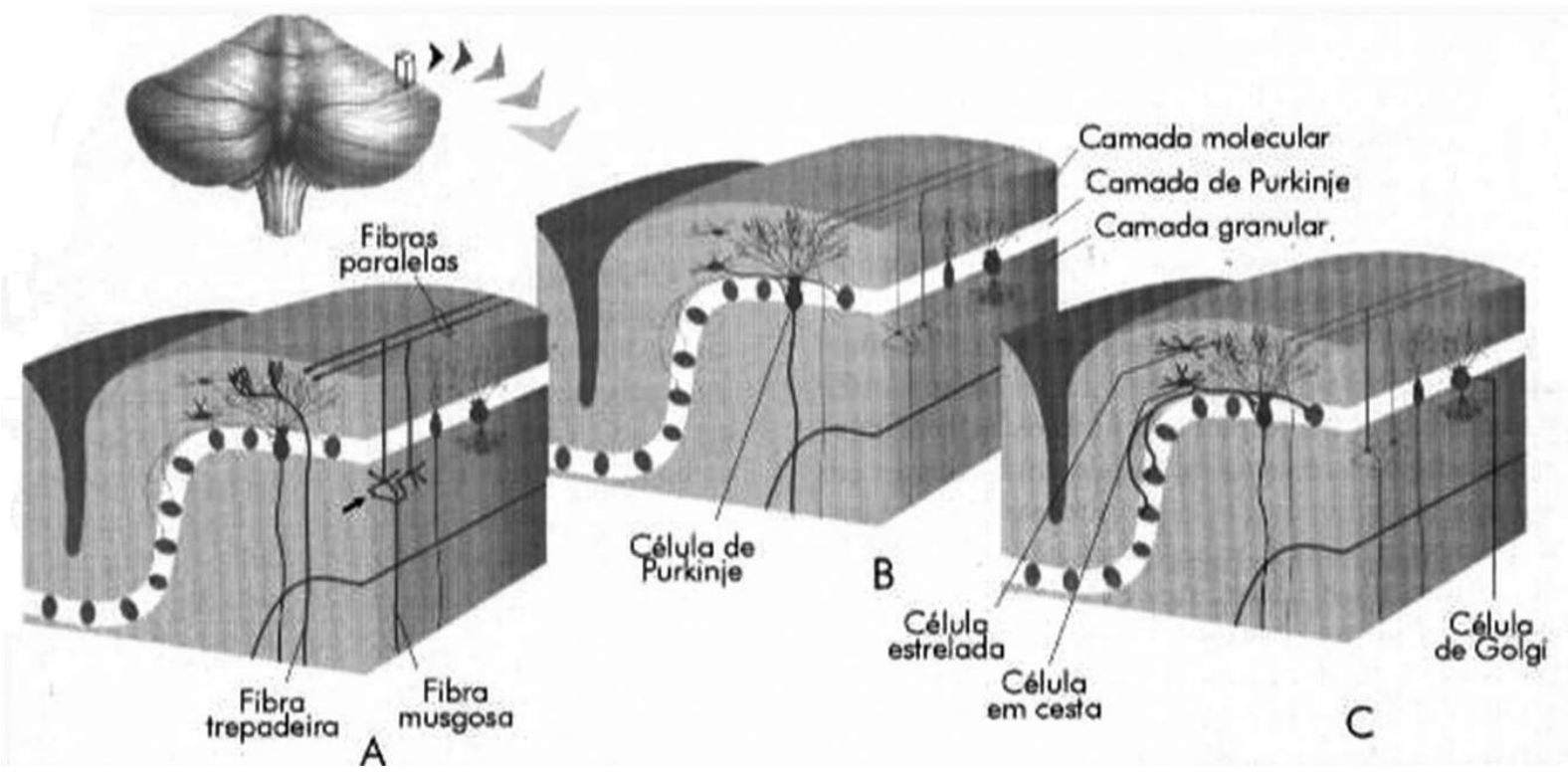

Figura 2. Representação das fibras e células que compõem as camadas do córtex cerebelar. Modificado de Martin (1996).

A camada molecular apresenta baixa densidade celular, arborizações dendríticas e axônios delgados de dois tipos de neurônios, que têm sua atividade 
facilitada pelas fibras paralelas: células em cesto, com axônios longos, que enviam ramificações dendríticas para a camada molecular e para o soma das células de Purkinje; e células estreladas externas, que apresentam axônios curtos, realizando contatos sinápticos com os dendritos distais das células de Purkinje (DelgadoGarcia, 2001), sendo ambas sinapses inibitórias (Eccles, 1970).

A camada das células de Purkinje é composta de células grandes dispostas ao longo da borda superior,. próximo à camada molecular. No colo das células de Purkinje, surge uma árvore dendrítica complexa estendendo-se na camada molecular e do lado oposto partem axônios mielinizados que caminham para a substância branca em direção aos núcleos cerebelares profundos, fazendo ali sinapses inibitórias (Eccles, 1970).

Ao redor das células de Purkinje, encontramos corpos celulares de células gliais ou de Bergmann que são compostas por astrócitos protoplasmáticos unipolares no córtex cerebelar; as fibras destes fazem sinapses com os dendritos das células de Purkinje. Às fibras das células de Bergmann estão associadas migração, dendritogênese, sinaptogênese e maturação das células de Purkinje (Yamada e Watanabe, 2002).

Já na camada granular, encontramos as células granulares cerebelares, que representa o tipo de neurônio mais numeroso no encéfalo (Bower e Parsons, 2003). Seus axônios ascendem para a camada molecular e se bifurcam formando as fibras paralelas que fazem sinapses excitatórias com as células de Purkinje (Eccles, 1970). Nesta camada temos também as células inibitórias de Golgi tipo II que se localizam na parte superior da camada, apresentando ramos dendríticos por todas as camadas do córtex cerebelar, porém mais extensos na camada molecular.

As duas aferências para o cerebelo são excitatórias e compostas pelas fibras musgosas e trepadeiras. As fibras musgosas, maior fonte de aferências do cerebelo, têm origem em núcleos do tronco encefálico e neurônios medulares que dão origem ao trato espinocerebelar, conduzindo então informações sensoriais periféricas, além de informações do córtex cerebral, e fazem sinapses excitatórias com dendritos das células granulares na camada granular. Esta aferência age diretamente sobre as células de Purkinje via fibras paralelas (Delgado- Garcia, 2001). 


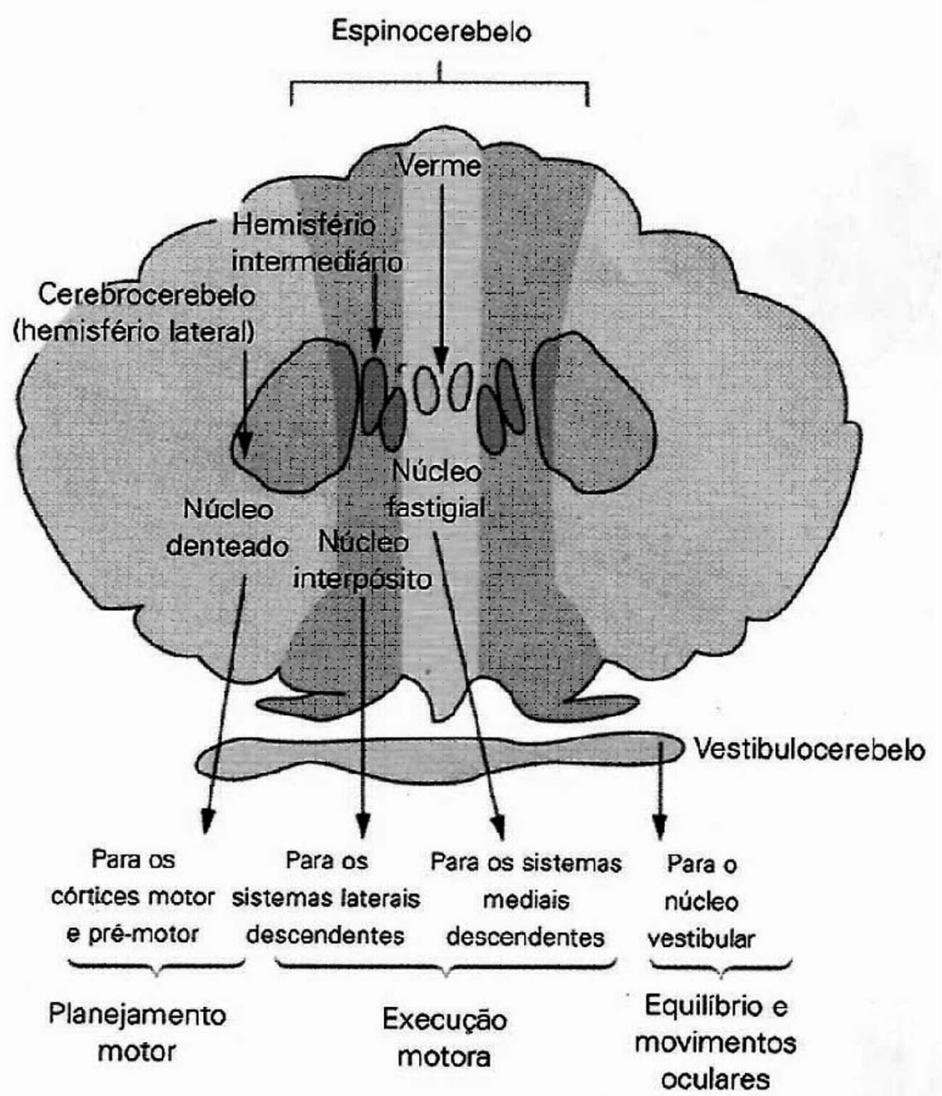

Figura 3. As três regiões funcionais do cerebelo com suas respectivas eferências. Adaptado de Kandel et al. (2003).

A origem das fibras trepadeiras se dá no núcleo olivar inferior e formação reticular medial, que recebem aferências do córtex cerebral, núcleo rubro e medula espinal. Estas conduzem informações sômato-sensórias, visuais e do córtex cerebral. As sinapses ocorrem entre o soma e os dendritos das células de Purkinje, e estas fibras podem modular o efeito das fibras musgosas por serem muito potentes. Tanto as fibras musgosas como as trepadeiras enviam colaterais para os neurônios dos núcleos cerebelares. Desta forma, os neurônios dos núcleos cerebelares recebem aferências excitatórias das fibras musgosas e trepadeiras e inibitórias das células de Purkinje. As informações aferentes provêm de receptores da pele, olho, sistema vestibular, músculos e articulações. Após passar pelas células de Purkinje, a informação segue para os núcleos cerebelares profundos, para então seguir seu destino pelas vias eferentes cerebelares (Delgado-Garcia, 2001).

O cerebelo apresenta quatro núcleos profundos, que são: denteado, emboliforme, globoso e fastigial, sendo que as junções do emboliforme com o 
globoso formam o interpósito. Estes núcleos recebem aferências glutamatérgicas das fibras trepadeiras e musgosas, que promovem correntes excitatórias póssinápticas mediadas por receptores do tipo NMDA e AMPA (Anchisi et al., 2000; Gauck e Jaeger, 2003); porém, em fração de segundos, áreas do córtex cerebelar correspondentes retransmitem um sinal inibitório via neurônios gabaérgicos (Gauck e Jaeger, 2003). Logo um mesmo sinal que entra no cerebelo e chega ao núcleo profundo como sinais excitatórios iniciais, são seguidos por sinais inibitórios, sendo que este sinal inibitório é "enviado" pelas células de Purkinje (Sarna e Hawkes, 2003); porém, as saídas dos núcleos cerebelares para áreas motoras são sempre excitatórias, apesar de sofrerem modulação do sinal, responsável por promover correção do movimento e aprendizado motor. Cada núcleo será responsável por projetar as informações vindas de regiões diferentes do córtex cerebelar, que por sua vez receberam informações funcionais distintas (Figura 3).

Filogeneticamente, as regiões laterais são as mais recentes. Recebem aferências exclusivamente do córtex cerebral, sendo por esta razão também são chamadas de cerebrocerebelo. As eferências desta região são mediadas pelo núcleo denteado, que projeta fibras para a região dos córtices motor, pré-motor e pré-frontal, através do tálamo, e assim esta área está intimamente envolvida com o planejamento e repetição mental de ações motoras complexas e na avaliação consciente de erros motores, sendo responsável pela coordenação de movimentos complexos iniciados no córtex, ou seja, movimentos voluntários, além das funções perceptivas, cognitivas e emocionais (Delgado-Garcia, 2001). Dessa forma, o núcleo denteado parece ser importante na aquisição e processamento de informações sensórias para tarefas que exigem um julgamento espacial e temporal complexo.

A expressão dos receptores de glutamato no cerebelo apresenta uma distribuição espacial e celular distinta, durante toda a vida, e temporal durante 0 desenvolvimento (Pires et al., 2006). Nas células de Purkinje há expressão de GluR1, 2 e 3, sendo mais expressos GluR1 flop, GluR2 flip/flop, GluR3 flip (Sommer et al., 1990; Monyer et al., 1991). As células de Bergmann possuem RNAm para GluR1 e GluR4 (Keinanen et al., 1990; Burnashev et al., 1992), sendo estes expressos na isoforma flip (Sommer et al., 1990; Monyer et al., 1991), permitindo assim alto influxo de cálcio na célula. Células granulares possuem RNAm para GluR2 e 4 (Keinanen et al., 1990; Sato et al., 1993), expressos como GluR2 e 4 flop 
(Sommer et al., 1990; Monyer et al., 1991). No cerebelo humano há maior expressão de mRNA GluR1, 3 e 4 da isoforma flip em células de Purkinje do que em células granulares, enquanto GluR2 apresenta a mesma quantidade das isoformas flip e flop, e assim a desenssibilização das células de Purkinje é mais lenta do que a das células granulares, e assim mais vulneráveis à excitotoxicidade mediada por receptores do tipo AMPA (Tomiyama et al., 1999). Estudos de PCR (Lambolez et al., 1992) e imuno-histoquímica (Petralia e Wenthold, 1992; Martin et al., 1993a) corroboram esses achados anteriores. Os interneurônios, ou seja, células em cesto, estreladas e células de Golgi, expressam GluR2, 3 e 4 (Martin et al., 1993a). Nos núcleos cerebelares profundos, estudos de Brorson et al. (1995) demonstraram haver uma rápida dessensibilização mediada por receptores do tipo AMPA em ratos. No núcleo denteado há expressão apenas de isoformas flop, principalmente do mRNA da subunidade GluR3 (Tomiyama et al., 1999), corroborando a idéia de que os neurônios do núcleo denteado apresentam rápida dessensibilização (Lambolez et al., 1996).

\subsubsection{Caracterização Anátomo-Funcional do Hipocampo}

O hipocampo é uma região do lobo temporal do cérebro, responsável por aspectos da neurobiologia da memória emocional e declarativa (memória de fatos e eventos). Processa a informação recentemente adquirida por um período de dias, semanas ou até meses, e depois a transfere para áreas importantes do córtex cerebral para um armazenamento mais prolongado (Kandel e Schwartz, 2000; Kampermann e Gage, 2002; Lary e Kandel, 2003). Seu nome deriva de seu formato curvado apresentado em secções coronais do cérebro humano, se assemelhando a um cavalo-marinho (Grego: hippos = cavalo, kampi = curva).

Composto por duas áreas principais: corno de Amon (subdividido em quatro campos - CA1, CA2, CA3 e CA4), e o giro denteado (GD), segundo van Groen et al. (2003), CA4 é a região da camada polimórfica do GD, também chamada de hilo ou região hilar (Brown e Zador, 1990). CA2 é pequeno e indistinto em algumas espécies, por este motivo ele é frequentemente incluído em CA1 (Blackstad, 1956; Van Groen, et al., 2003). O termo "formação hipocampal" inclui o GD, o subículo, o 
hipocampo propriamente dito, além dos córtices entorrinal, perirrinal e paraipocampal (Brown e Zador, 1990).

As subdivisões CA1-3 são constituídas por camadas, sendo elas: stratum alveus (camada mais superficial), stratum oriens, stratum pyramidale, stratum lucidum (presente apenas em CA3), stratum radiatum e stratum lacunosummoleculare (contínuo com o GD) (Santos, 1995; Franklin e Paxinos, 1997; Brown e Zador, 1990) (Figura 3). O GD consiste em camada molecular (stratum moleculare), camada granular (stratum granulosum) e camada polimórfica do GD ou hilo (Brown e Zador, 1990; Santos, 1995; Fujise et al., 1998) (Figura 4).

O stratum pyramidale abriga as principais células do hipocampo, as células piramidais, que estão muito próximas umas às outras, formando uma região compacta, e enviando dendritos basais para o stratum oriens e dendritos apicais em direção à fissura hipocampal. No stratum oriens, há dendritos basais de células piramidais e diferentes classes de células e interneurônios. Após a camada piramidal, apenas em CA3, encontramos o stratum lucidum ocupado por fibras musgosas das células granulares, responsáveis em enviar as informações do GD para o hipocampo (Matyas et al., 2004). O stratum radiatum em CA1 e CA2 está logo após a camada piramidal e em CA3 após o stratum lucidum, podendo ser definido como supra-piramidal. No stratum oriens e stratum radiatum encontram-se conexões associativas CA3/CA3 ou as projeções de CA3 para CA1, chamadas de colaterais de Schaffer. A última camada é contínua com o giro denteado, chamada de stratum lacunosum-moleculare. Nesta camada chegam as fibras do córtex entorrinal e aferências de outras regiões, como por exemplo, da região mediana do tálamo. O stratum radiatum e lacunosum-moleculare abrigam vários tipos de interneurônios (Andersen et al., 2007). Os interneurônios estão localizados em todas as camadas. Entre eles temos, por exemplo, células em cesto, piramidais ou células axo-axônicas, que estão bem próximas às células piramidais, sendo a maioria gabaérgicas (Ribak et al., 1978, 1981). 


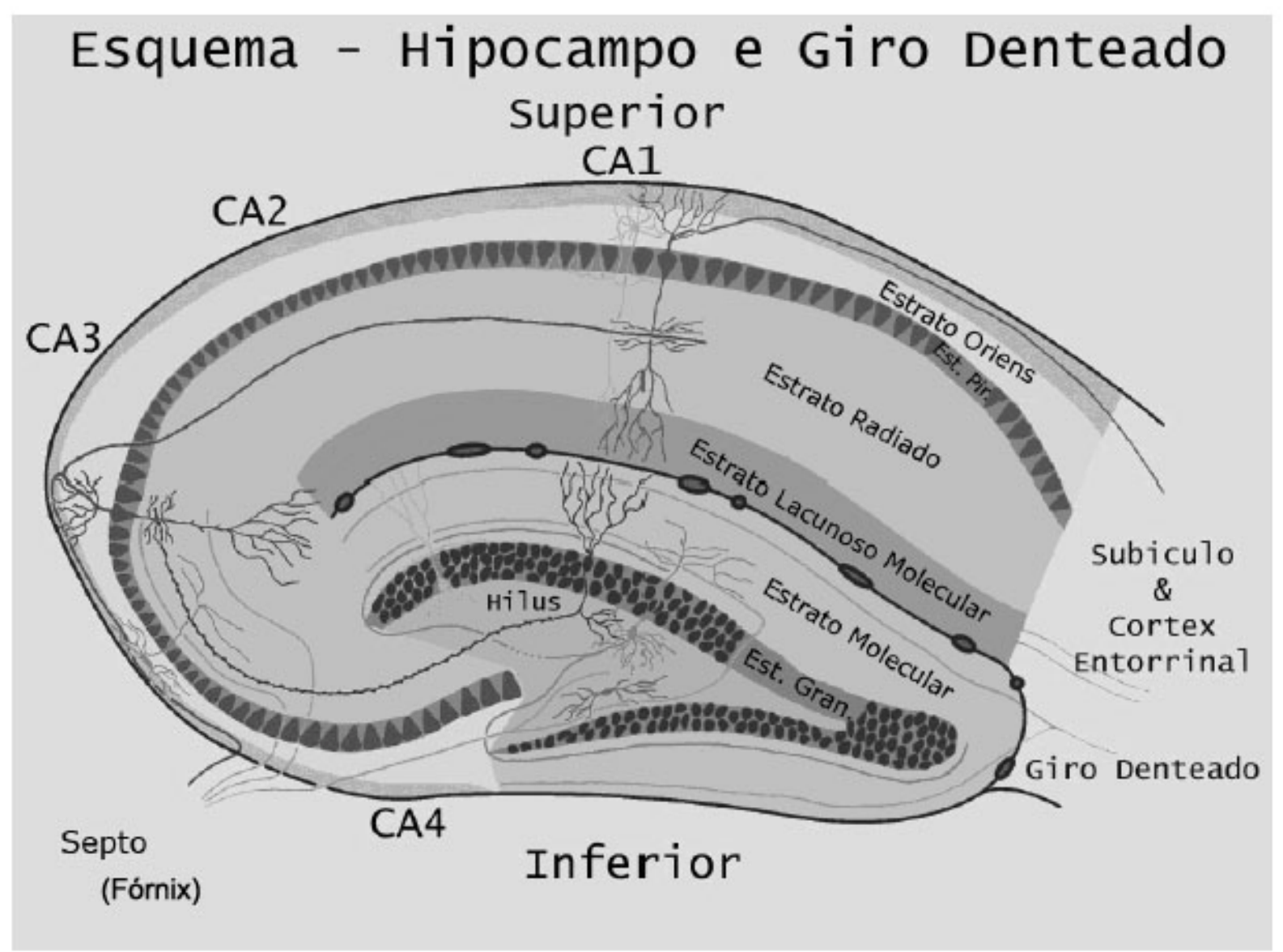

Figura 4. Representação simplificada das camadas celulares do hipocampo e GD. Corno de Amon (CA1, CA2, CA3, CA4). Modificado de Diniz (2006).

No GD as principais células e que se encontram próximas umas às outras raramente havendo uma célula glial entre elas (Claiborne et al., 1990), são as células granulares (CG), localizadas na camada granular. A arborização dendrítica das CG direciona-se para a porção mais superficial da camada molecular, muitas vezes terminando exatamente na fissura hipocampal ou superfície ventricular. Essas células são excitatórias e realizam sinapses glutamatérgicas (Miyamoto, 2006). Estudos demonstraram que há cerca de $1,2 \times 10^{6}$ CG no GD (West et al., 1991; Rapp e Gallagher, 1996) desde o nascimento (Rapp e Gallagher, 1996). Kempermann et al. (1997) demonstraram que camundongos jovens expostos a ambiente rico ou que realizavam atividade em roda apresentavam maior número de CG no giro, levando ao aumento da estrutura, aumento este que se manteve no animal adulto. No entanto, se a manipulação fosse feita no animal já adulto, apesar de haver proliferação celular e neurogênese (Kempermann et al., 1998; van Praag et al., 
1999;) não há alteração do volume da região (Kempermann et al., 1998). Além disso, o exercício favorece a sobrevivência e maturação de CG (Snyder et al., 2009).

Outro tipo celular na camada granular são os interneurônios, sendo os principais as células em cesto que se localizam na superfície mais profunda da camada. Estas projetam axônios que fazem sinapse com o corpo das CG, além de seus dendritos comunicarem-se com a camada molecular e as células polimórficas. A maioria destas células apresenta características de neurônios inibitórios (gabaérgicos) (Ribak et al., 1978). Em 1996, Freund e Buzsaki descreveram em uma revisão outros tipos de interneurônios presentes no hipocampo, que também fazem sinapse com corpos celulares, axônios e fibras serotonérgicas provenientes do núcleo da rafe.

A camada molecular do GD é composta basicamente por dendritos das células granulares, células em cesto e células polimórficas, bem como por axônios do córtex entorrinal e outras regiões. Encontramos também dois tipos celulares na região: o primeiro possui corpo celular triangular ou multipolar e localiza-se na região mais profunda da camada (Han et al., 1993); o segundo, descrito por Soriano e Frotscher (1989), é encontrado próximo à superfície da camada granular e recebe o nome de axo-axônico, pois os axônios destas células penetram a camada granular e fazem sinapse com o segmento inicial do axônio das CG. Esta conexão é gabaérgica, sendo então responsável por controlar a atividade das CG.

$\mathrm{Na}$ camada de células polimórficas encontram-se diferentes tipos celulares, porém as mais comuns são as células musgosas. Estas apresentam corpo celular grande em formato triangular ou multipolar, e possivelmente são as células descritas por Ramon y Cajal (Llinas, 2003) como "estreladas ou triangulares" localizadas na subzona de células fusiformes ou por Lorente de Nó como "piramidais modificadas" (Lorente Nó, 1934). Estas células possuem dendritos que se bifurcam e chegam às outras camadas do giro, porém não fazem conexões com áreas que não pertencem ao giro. São células imunorreativas para o glutamato, sendo assim a maior fonte de excitação associativa no GD (Andersen et al., 2007).

A comunicação eferente do GD ocorre unicamente com a região CA3 do hipocampo, através das fibras musgosas das CG que terminam nos dendritos apicais das células piramidais de CA3, stratum lucidum (nome dado devido a aparência clara dada ao tecido fresco pela falta de mielina nas fibras musgosas) 
(Blackstad et al., 1970 apud Andersen et al., 2007). Walker et al. (2002) demonstraram que o transmissor primário das CG é o glutamato, apesar de também poderem ser imunorreativas para peptídeos opióides e GABA após crises epiléticas.

As fibras provenientes do córtex sensorial e associativo são as principais aferências para o hipocampo. Os axônios corticais fazem sinapse com neurônios do córtex entorrinal, iniciando uma sequência de sinapses glutamatérgicas. Assim, toda informação que chega ao hipocampo provêm do córtex entorrinal, e esta informação é encaminhada às diversas vias hipocampais que envolvem o GD e o corno de Amon; a saída do sinal ocorre pelo subículo, que devolve a informação ao córtex entorrinal, e este envia fibras para os córtices parahipocampal e perirrinal, voltando então a informação modificada às áreas do córtex cerebral (Figura 5) (Andersen et al., 2007).

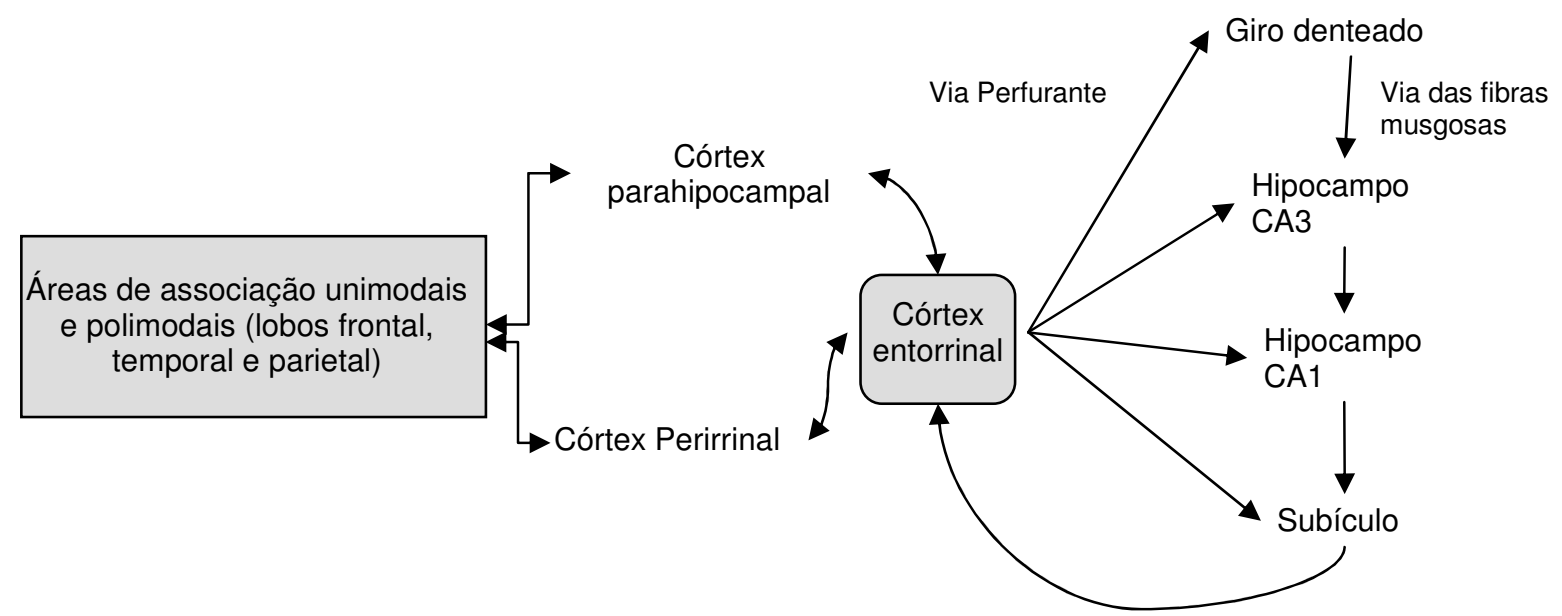

Figura 5. Vias de entrada e saída hipocampal. Modificado de Kandel et al. (2003).

O circuito tri-sináptico é o mais conhecido, sendo responsável por propagar a informação no interior do hipocampo. A informação do córtex entorrinal é enviada aos dendritos das células granulares do GD, constituindo a via perforante. As células granulares do GD enviam axônios, chamados de fibras musgosas, responsáveis pela potenciação de longo prazo (LTP) não associativa, ou seja, que não depende de atividade pós-sináptica ou de outros sinais chegando simultaneamente, dependendo apenas de um pequeno surto de atividade neural de alta frequência nos neurônios pré-sinápticos e do consequente influxo de cálcio para fazer a segunda sinapse com as células piramidais de CA3. Os neurônios de CA3 projetam colaterais axônicos excitatórios que se ramificam formando os colaterais de Schaffer. Neste 
caso a LTP é do tipo associativa, ou seja, requer atividade concomitante tanto pré quanto pós-sináptica. Assim, a LTP só pode ser induzida na via das colaterais de Schaffer se receptores do glutamato do tipo NMDA forem ativados nas células póssinápticas), e outro ramo que deixa o hipocampo pelo fórnix. A via colateral de Schaffer faz a terceira sinapse com células piramidais de CA1, fechando o circuito trisináptico básico do hipocampo (Bliss e Collingridge, 1993; Sutula et al., 1998; Leite e Cavalheiro, 1998; Torres, 2005) e consolidando a memória declarativa (Kandel et al., 2000; Bear et al., 2001) (Figura 6).

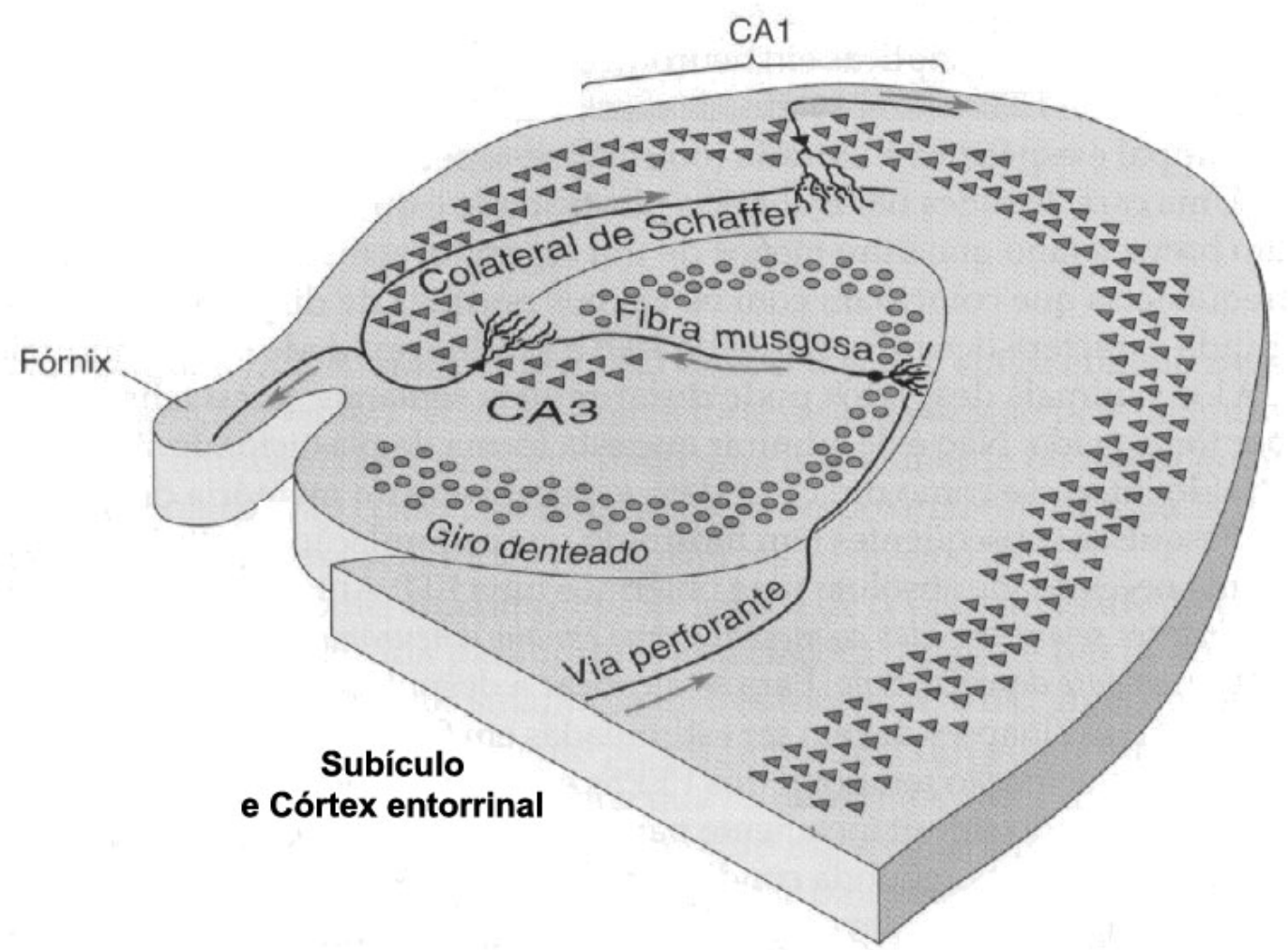

Figura 6. Representação simplificada do circuito tri-sináptico do hipocampo. $O$ GD recebe as projeções do córtex entorrinal através da via perfurante (1 $1^{a}$ sinapse) e projeta através dos axônios das células granulares para CA3 (2a sinapse). Este último projeta para CA1 ( $3^{a}$ sinapse) através dos axônios das células piramidais. Modificado de Bitencourt, 2005.

Estudos do hipocampo mostraram ser o glutamato o principal responsável pelos mecanismos que promovem aprendizado e memória, tais como transmissão e plasticidade sináptica. A ativação dos receptores ionotrópicos permite que ocorra a LTP (mecanismos descritos posteriormente em neuroplasticidade), bem 
caracterizada no hipocampo. O pico de expressão dos receptores ionotrópicos em camundongos ocorre após 2 semanas do nascimento, momento que ocorre 0 mesmo com a subunidade $\alpha$ da CaM kinase II, responsável por mecanismos moleculares da plasticidade sináptica e aprendizado (Andersen et al., 2007).

As sinapses excitatórias que participam das funções do hipocampo ocorrem através dos receptores do tipo AMPA, porém a distribuição das subunidades é bem variada entre as camadas (Toth e McBain, 1998) e até mesmo ao longo do dendrito (Magee e Cook, 2000), gerando receptores com propriedades diferentes, conforme a atividade celular. As células principais, ou seja, granulares e piramidais, expressam apenas GluR1 e GluR2 em estágios embrionários, porém posteriormente há também uma baixa expressão de GluR3 e GluR4, apesar da predominância continuar sendo de GluR1 e GluR2 (Keinanen et al., 1990; Petralia e Wenthold, 1992). Os canais formados pelos receptores são predominantemente compostos por GluR1/2, alguns por GluR2/3 e apenas GluR1, sendo que as subunidades do tipo GluR2 são da forma editada, possibilitando baixo influxo de cálcio. Quanto às isoformas flip e flop de GluR1, 2 e 3, ambas são expressas em células piramidais de CA1, porém em CA3 há expressão apenas da isoforma flip. Na região do giro denteado flip e flop estão presentes, porém há predomínio da isoforma flop (Sommer et al., 1990; Monyer et al., 1991). Já os interneurônios hipocampais expressam principalmente as subunidades GluR1 e GluR4. Desta forma, permitem alto fluxo de cálcio pelos canais (Geiger et al., 1995), havendo um predomínio da isoforma flop (Monyer et al., 1991).

A subunidade NR1 é expressa em células do GD, em todos os neurônios piramidais e em muitos interneurônios (Laurie e Seeburg, 1994; Monyer et al., 1994), porém as diferentes isoformas são expressas de forma distinta no hipocampo. NR1a, NR1-1, e NR1-2 são predominantes nas células da camada piramidal durante o desenvolvimento. Em geral, NR1-4 e NR1b apresentam baixa expressão, estando mais presentes na camada piramidal de CA3. NR1-3 apresentam baixa expressão em todas regiões do hipocampo (Laurie e Seeburg, 1994). A heterogeneidade da localização e constituição do receptor permite respostas distintas nos neurônios póssinápticos e assim, uma atividade adequada dos circuitos envolvidos nas funções do hipocampo, tais como aprendizado e memória, podendo ser memória de curto ou longo prazo. A de longo prazo depende de alterações na expressão de genes, 
podendo ser dividida em duas modalidades: declarativa ou não, e assim envolver diferentes áreas do encéfalo; por exemplo, a memória pode ser adquirida por condicionamento operante que requer atividade do estriado e do cerebelo, como ocorre na atividade física, ou o condicionamento clássico, a sensibilização e a habituação, sendo essa incumbência dos sistemas motor e sensório, como esquematizado na figura abaixo (Figura 7).

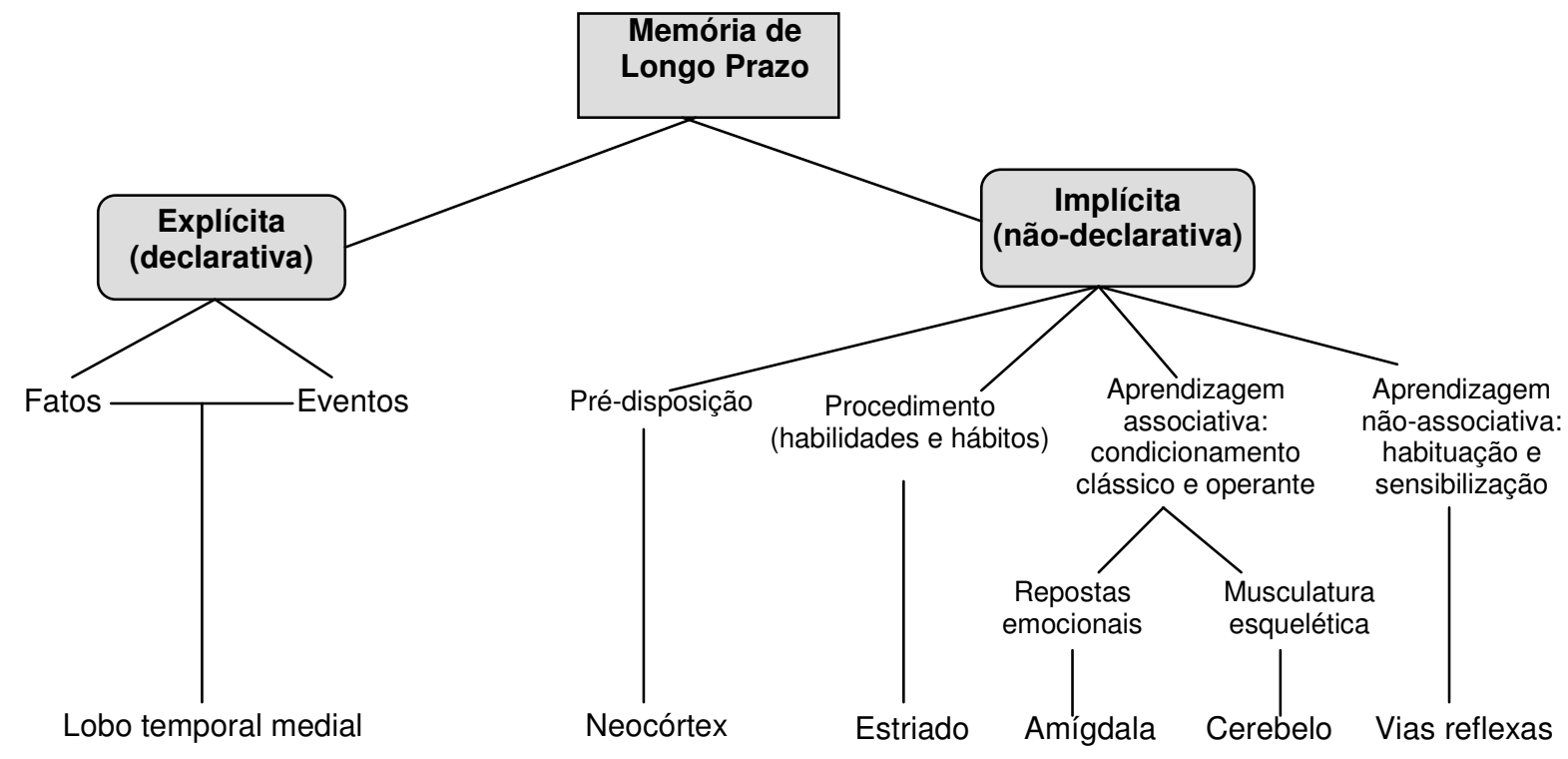

Figura 7. As várias formas de memória podem ser classificadas como explícita (declarativa) ou implícita (não-declarativa). Modificado de Kandel et al. (2003).

Estudos da ação da atividade física no hipocampo demonstraram que, além da indução da LTP devido aumento na atividade glutamatérgica, há aumento da neurogênese no GD do hipocampo de adultos e idosos, e assim os novos neurônios podem estar associados à aprendizagem e mudanças no comportamento cognitivo (van Praag, 2008; Fabel e Kempermann, 2008). Observou-se também aumento de fatores neurotróficos responsáveis por proteção contra o efeito excitotóxico por glutamato (Jiang et al., 2005), e também melhora da LTP, como será explicado adiante (Molteni et al., 2002). 


\subsubsection{Caracterização Anátomo-Funcional do Córtex Motor}

O córtex cerebral recebe impulsos glutamatérgicos provenientes de todas as vias sensoriais, e assim a informação periférica torna-se consciente e é interpretada para promover uma resposta adequada. Em 1870, os alemães Fritsch e Hitzig descobriram que a estimulação de partes do lobo frontal produzia movimentos distintos no lado oposto do corpo, quando foram iniciadas pesquisas para caracterizar as áreas cerebrais com suas respectivas funções. Em 1909, Korbinian Brodmann propôs uma subdivisão citoarquitetônica do córtex em 52 regiões, a qual é amplamente aceita até hoje. As áreas foram divididas de acordo com a função de cada região (Figura 8). Todas as áreas propostas por Brodmann são compostas por uma camada mais fina e superficial de substância cinzenta e uma mais interna de substância branca.
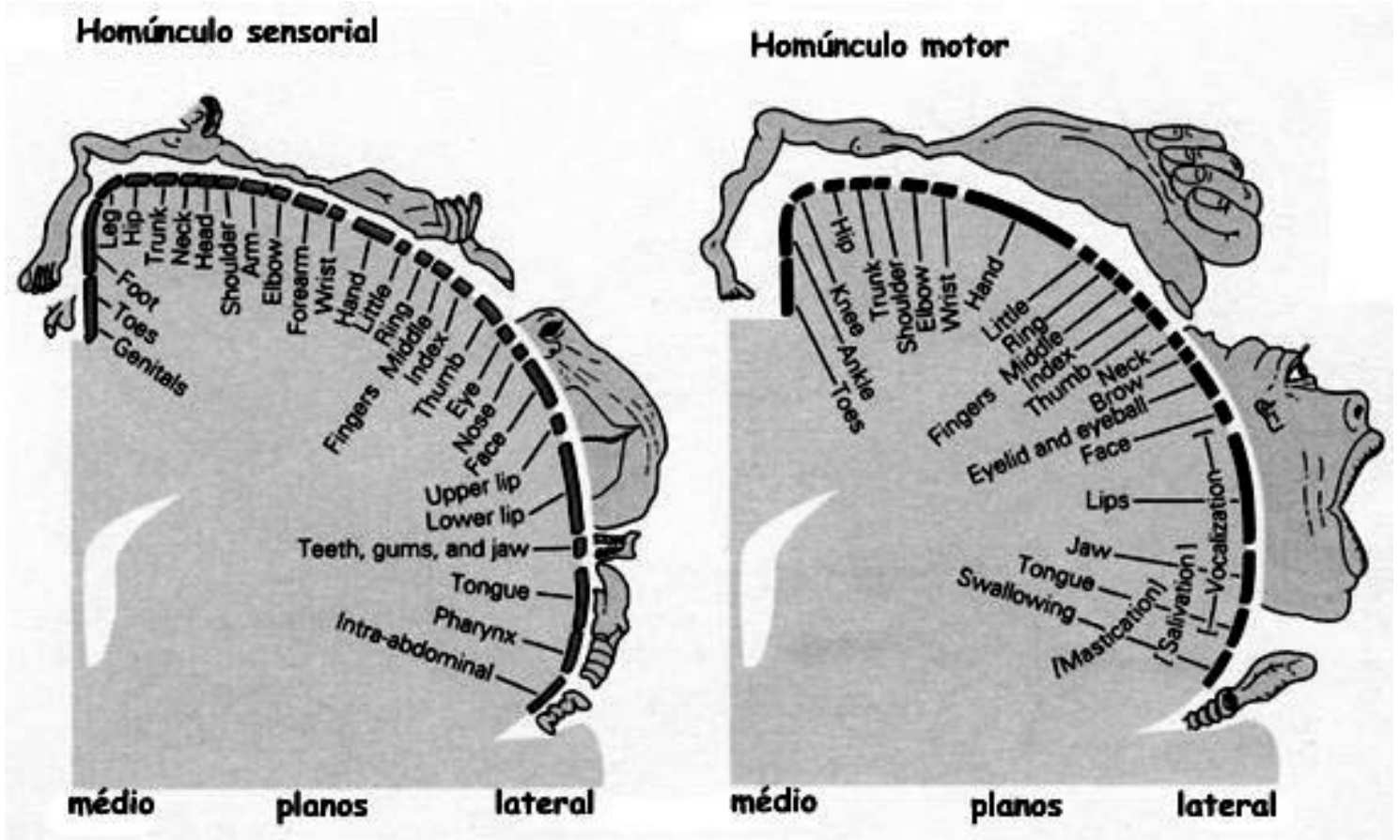

Figura 8. Organização somatotópica de áreas sensoriais e motoras. Retirado de curlygirl.naturlink.pt/homunculi.jpg.

O córtex cerebral apresenta-se organizado em seis camadas numeradas de IVI, como descrito por Lorente de Nó em 1949. Estas camadas são compostas basicamente por três tipos celulares: células granulares ou estreladas (interneurônios); células fusiformes e células piramidais (originam fibras eferentes do córtex cerebral), variando apenas a quantidade de cada uma na região analisada. 
No córtex sensorial, por exemplo, são encontradas mais células granulares por serem receptoras das informações, enquanto que no córtex motor encontramos mais células piramidais, origem das vias eferentes. Nas camadas I, II e III encontramos fibras de associação, na IV estão as fibras aferentes, na $V$ temos células que dão origem às fibras eferentes, chamadas também de células de Betz na área motora primária, isto é, que deixam o córtex cerebral indo para o tronco encefálico, medula espinal e núcleos da base, e na VI temos as fibras que partem desta zona em direção ao tálamo. Assim, os neurônios localizam-se nas camadas correspondentes à sua função, como pode ser visto na ilustração abaixo (Figura 9).

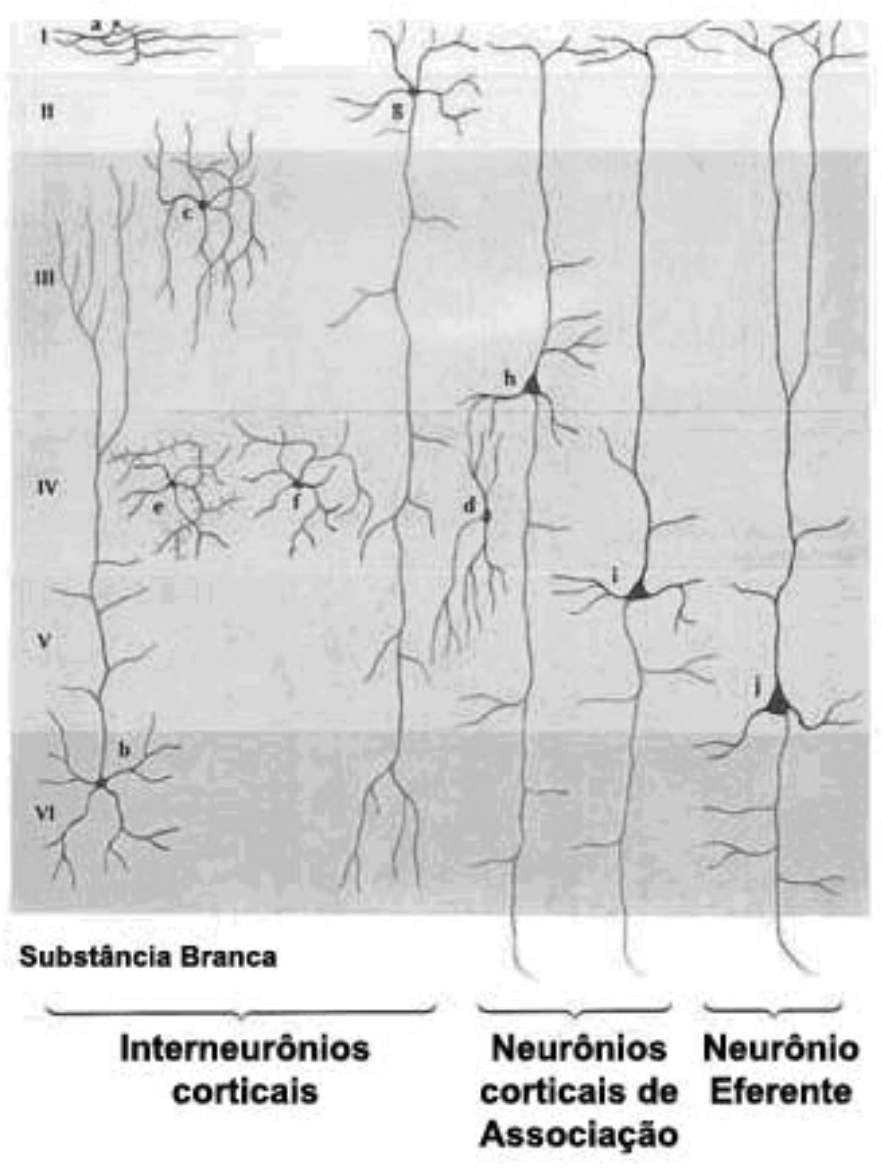

a - célula horizontal

b- célula de Martinotti

c- célula tipo chandelier

d- célula granular

e- célula granular espinhosa

f- célula granular estrelada

g- células piramidais pequenas das camadas II e III

h- células piramidais pequenas de associaçăo

i- células piramidais pequenas de associação e projeção da Camada V j-células piramidais grandes de projeçăo (células de Betz)

Figura 9. Imagem ilustrativa das camadas e células que compõem o córtex cerebral. Modificado do atlas digital F. Netter (1999). 
As áreas motoras do córtex cerebral são subdivididas em área motora primária e em várias áreas pré-motoras (áreas motoras secundárias). A área motora primária é responsável por executar o movimento e as outras por planejar o movimento, participando de padrões de movimento mais complexos.

O córtex motor primário refere-se à área 4 de Brodmann, e assim como 0 córtex sensorial, possui uma representação somatotópica que representa cada região corpórea. Esta representação existe em todas as espécies animais, como o rato (Neafsey et al., 1986), variando apenas o tamanho e a localização conforme a complexidade e importância do ato motor, ou alterações plásticas devido a mudanças sensoriais ou motoras, como foi mostrado por Sanes et al. (1990) em ratos.

Os neurônios do córtex motor primário recebem aferências do córtex sômatosensorial primário (áreas 1,2 e 3) (Wiesendanger, 1973); da área 5 do córtex parietal posterior que está envolvida com a integração de múltiplas modalidades sensoriais para o planejamento motor; do cerebelo e dos núcleos da base através de núcleos do tálamo ventrolateral, além das projeções de áreas pré-motoras. As áreas prémotoras referem-se à área 6 de Brodmann; estas recebem aferências das áreas 5 e 7 do córtex parietal e 46 do córtex pré-frontal, importantes no processamento da memória operacional, além de conexões entre áreas pré-motoras e de projeções do tálamo que veiculam informações provenientes do cerebelo e núcleos da base. Desta forma, o movimento ocorre de forma rápida e precisa. A resposta motora é enviada por fibras eferentes originadas das células piramidais ou células de Betz (células piramidais gigantes da camada V), formando o trato corticoespinal (trato piramidal) que chega à medula para ativar grupos musculares que participarão na execução do movimento (Asanuma, 1989; Kandel e Schwartz, 2000). Estudos que realizaram secção unilateral da via piramidal demonstraram que após uma semana o animal já realizava a atividade motora porém com maior lentidão da resposta, sugerindo que a via participe do aprendizado motor e sua memorização (Laursen e Wiesendanger, 1967; Laursen, 1970; Asanuma et al. 1981).

As conexões que ocorrem nas áreas corticais são mediadas pelo sistema glutamatérgico e seus respectivos receptores, que já foi descrito acima. Logo, qualquer mudança nos circuitos sensório-motores é capaz de promover plasticidade neuronal. As subunidades do tipo AMPA estão distribuídas em células piramidais e 
não piramidais do córtex (Petralia e Wenthold, 1992) apesar de Martin et al. (1993a) terem descrito expressão de GluR4 apenas em astrócitos. Os neurônios não piramidais expressam intensamente GluR1 (Petralia e Wenthold, 1992) e a proteína ligante de cálcio calbindina (Martin et al., 1993a). Keinanen et al., (1990) realizaram estudos de hibridização in situ no córtex de ratos e demonstraram que os mRNAs de GluR1, 3 e 4 apresentam distribuições distintas pelas camadas corticais, enquanto 0 mRNA de GluR2 encontra-se uniforme. Baixa intensidade de marcação para GluR1 e GluR3 é encontrada nas camadas III e IV, porém a expressão de GluR4 é intensa nestas camadas. Estudos de Huntley et al. (1994a,b) demonstraram que a distribuição de NR1 varia entre camadas e áreas corticais, estando assim a subunidade envolvida com a plasticidade neuronal local e de circuitos excitatórios extrínsecos. Bland et al. (1999), demonstraram que a atividade motora promove aumento dos níveis de glutamato extracelular circulante no córtex sensório-motor. Experimentos com camundongos que praticaram 4 semanas de exercício físico voluntário demonstraram haver modulação das sinapses glutamatérgicas, provavelmente pelo aumento da atividade glutamatérgica, que envolve fosforilação de subunidades NR1 e NR2B de receptores glutamatérgicos, aumento das proteínas responsáveis em ancorar os receptores na membrana, tais como PSD-95, SAP-97 e GRIP-1, além de aumento da imunorreatividade para GluR1 e GluR2/3. Assim, o exercício voluntário promove reorganização pós-sináptica dos circuitos glutamatérgicos (Dietrich et al., 2005).

\subsubsection{Caracterização Anátomo-Funcional do Estriado}

Durante a execução do movimento voluntário há a participação de um complexo de núcleos subcorticais que se interconectam, chamados de núcleos da base (Mink, 1999). Estes são responsáveis pela maioria dos programas motores de rotina, além de participarem na formação de memória e aprendizado (Fearnley e Lees, 1991; Calne, 1994). Os núcleos da base são constituídos por quatro estruturas, sendo elas: estriado (acumbens, caudado e putâmen), globo pálido (externo e interno), substância negra (parte compacta e reticulada) e núcleo subtalâmico. O estriado, por sua vez, ao excluirmos o pólo anterior onde se localiza 
o núcleo acumbens, é subdivido por uma cápsula interna em caudado e putâmen, formado uma estrutura chamada de neoestriado, porém didaticamente encontramos referência como apenas estriado (Mink, 1999). Os núcleos caudado e putâmen, apesar de separados pela cápsula interna, apresentam características citoarquitetônicas homogêneas (Carpenter, 1976), porém anátomo-funcionalmente heterogêneas. Em alguns mamíferos, inclusive em ratos, é comum referir-se ao estriado como caudado-putâmen pois a divisão dos núcleos não é clara (Nauta e Domesick, 1984).

O estriado é composto por vários tipos celulares, porém cerca de 90-95\% deles são neurônios gabaérgicos com espinhos dendríticos, que são os alvos das aferências corticais e a sua única fonte de fibras eferentes (Gerfen, 1988). Estes neurônios permanecem quiescentes a maior parte do tempo, exceto durante movimentos ou em resposta a um estímulo periférico. Os neurônios gabaérgicos podem ser divididos em subtipos conforme a expressão de outros neuromediadores e a via eferente, podendo ser: 1) que se projetam para o globo pálido externo (GPe), expressam o neuropeptídeo encefalina e assim, inibem movimentos indesejáveis; 2) que se projetam para o globo pálido interno (GPi), contêm substância $P$ e facilitam o planejamento de movimentos do tronco e membros; 3) neurônios que contêm substância $\mathrm{P}$, porém se projetam para a substância negra reticulada ( $\mathrm{SNr}$ ), atuando no planejamento dos movimentos da cabeça e olhos; e 4) os que contêm substância $\mathrm{P}$, projetando-se para a substância negra compacta $(\mathrm{SNc})$, responsável por modular o sistema dopaminérgico que se projeta para o estriado (Bolam, 1984; Albin et al., 1989; Graybiel, 1990; Gerfen, 1992). Além desses neurônios, o estriado possui poucos interneurônios inibitórios locais, sendo estes: 1) grandes neurônios colinérgicos (Graybiel, 1990; Gerfen, 1992; Kawaguchi et al., 1995; Bennett et al., 2000); 2) células que contêm GABA, somatostatina, neuropeptídeo Y ou óxido nítrico sintase (Kawaguchi et al., 1995; Figueredo-Cardenas et al., 1996a); 3) neurônios que contêm GABA e parvalbumina (Kawaguchi et al., 1995); 4) e os que contêm GABA e calretinina (Kawaguchi et al., 1995; Cicchetti et al., 1999, 2000). Os axônios dos interneurônios são colaterais extensos que reduzem a atividade dos neurônios eferentes do estriado, sendo responsáveis pela atividade tônica do estriado (Bolam, 1984; Kawaguchi et al., 1995; Figueredo-Cardenas et al., 1996). 
No modelo descrito por Alexander e Crutcher (1990), o estriado é considerado o principal núcleo do circuito por ser o responsável por receber aferências glutamatérgicas, mediadas por receptores do tipo AMPA (Kita, 1996; Calabresi et al., 1998) topograficamente organizadas de todas as regiões corticais (através do circuito corticoestriatal) (Goldman e Nauta, 1977), aferências excitatórias dos núcleos intratalâmicos, projeções dopaminérgicas da substância negra compacta e aferências serotonérgicas dos núcleos da rafe. O estriado é o componente com maior diversidade de neurotransmissores nos núcleos da base, com cerca de 40 tipos (Graybiel e Ragsdale, 1983), e assim representa um complexo circuito neuroquímico.

Com a chegada de aferências glutamatérgicas ocorrem sinapses excitatórias com neurônios GABAérgicos espinhosos médios, responsáveis por originar as duas vias eferentes do estriado, sendo uma direta (GABA/substância P) e outra indireta (GABA/encefalina). As eferências do estriado permitem a esse núcleo comunicar-se com o GPi e SNr, através das quais toda a informação processada nos núcleos da base é enviada à medula, através do núcleo pedúnculo-pontino ou ao tálamo e deste de volta à região cortical de origem (Noback et al., 1999). Com a ativação das vias diretas ocorre inibição dos neurônios gabaérgicos do GPi e SNr, e assim ocorre desinibição talâmica. A ativação da via indireta promove inibição do globo pálido externo (GPe) e consequentemente desinibição do núcleo subtalâmico (NST), pois este é inibido por neurônios gabaérgicos do GPe. O NST, por sua vez, possui neurônios glutamatérgicos responsáveis por ativar a atividade inibitória do GPi, promovendo assim inibição dos neurônios dos núcleos-alvos. Assim, a ativação das vias direta e indireta promove respostas distintas nos núcleos talâmicos ventrolateral e centro-mediano (Blandini et al., 2000; Obeso et al., 2000) (Figura 10).

As subunidades de receptores de glutamato encontram-se dispersas em toda a estrutura de forma distinta (Martin et al., 1993). GluR1 é a mais expressa, com predomínio em células gabaérgicas (Petralia e Wenthold, 1992; Martin et al., 1993a,b). Tallaksen-Greene e Albin (1994) descreveram que a maioria dos neurônios de projeção estriado-nigral e estriado-palidal expressavam GluR2/3/4, enquanto não houve marcação para GluR1 em nenhum neurônio de projeção estriatal. Já os diferentes tipos de interneurônios apresentaram imunorreatividades distintas: os interneurônios que expressavam parvalbumina também continham 
GluR1; os imunorreativos para somatostatina não expressam qualquer subunidade do tipo AMPA. GluR4 não aparece em células do estriado. O mesmo grupo de estudo dos dados anteriores relatou que $40 \%$ dos neurônios de projeção estriadonigral expressam GluR2flop, 20\% GluR3flop, 10-15\% GluR2flip e 10\% GluR3flip, enquanto que $35 \%$ dos neurônios da via estriado-palidal expressaram GluR3flop, 20\% GluR2flop, 15-20\% GluR3flip e 10\% GluR2flip. Estes dados sugerem que há baixos níveis de GluR2 e consequentemente maior entrada possível de cálcio. Estas eferências são, assim, mais vulneráveis à excitotoxicidade (Tallaksen-Greene e Albin, 1996). Estes estudos demonstraram que as subunidades dos receptores do tipo AMPA aparecem em diferentes tipos celulares, sugerindo que cada população de neurônios estriatais expressa composição do receptor conforme a sua especificidade funcional, podendo sofrer alterações plásticas fisiológicas ou não, tais como ocorrem na doença de Parkinson ou no exercício físico, sendo capazes de alterar a circuitaria glutamatérgica.

Deng et al. (2007) demonstraram ser mais comum a expressão de GluR1 em espinhos dendríticos de neurônios que se projetam para o GPe e interneurônios parvalbumina-positivos, e de GluR2 nos que se projetam para SNr e GPi e menos abundante em interneurônios. A proporção existente entre GluR1/GluR2 no corpo celular de neurônios de projeção e nos interneurônios foi: estriado-GPe>estriadoSNr>estriado-GPi e interneurônios parvalbuminérgicos>interneurônios calrretinérgicos> interneurônios colinérgicos>neurônios de projeção> interneurônios somatostatinérgicos. Assim, esta proporção é capaz de demonstrar quais os neurônios são mais susceptíveis à excitoxicidade, sendo eles os que expressam parvalbumina e calretina, proteínas tamponantes de cálcio. Porém, devemos lembrar que a ausência de GluR2 permite maior condutância pelo canal e uma dessensibilização mais rápida na ativação pelo córtex, e respostas de correção motoras mais rápidas (Kawaguchi, 1993;Martin et al., 1993; Tallaksen-Greene e Albin, 1994; Koos e Tepper, 1999). 


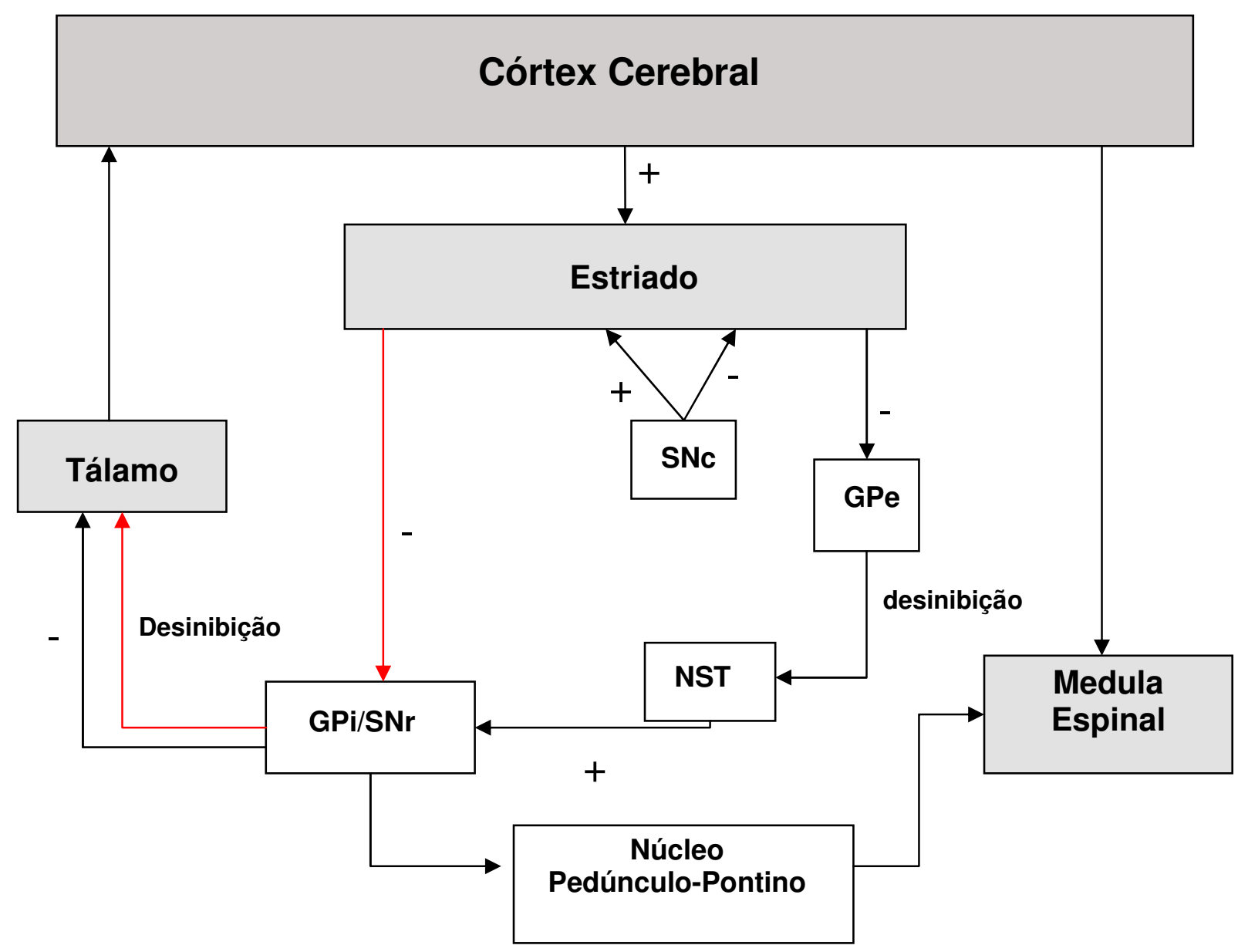

Figura 10. Circuito dos núcleos da base. As setas vermelhas representam a via direta do estriado e as pretas a via indireta. Note que a via direta promove desinibição do tálamo, enquanto a indireta promove inibição. Adaptado de Alexander e Crutcher (1990).

Outros estudos vêm esclarecendo as alterações promovidas pela atividade física no estriado. Bland et al. (1999) demonstraram por microdiálise que o movimento dos membros de ratos promove aumento nos níveis extracelulares de glutamato. Por outro lado, a imobilização do membro promove diferenças hemisféricas na concentração de glutamato. Além do acréscimo dos níveis de glutamato, a corrida forçada em esteira promove angiogênese na região (Ding et al., 2003; 2004a,b,c; 2006), melhorando a demanda de oxigênio e glicose para os neurônios que estão ativos (Isaacs et al., 1992; Vissing et al., 1996). Associado aos períodos de proliferação endotelial, há aumento na proliferação de astrócitos em ambos hemisférios cerebrais, mostrando que a resposta ao exercício fisco é global, sugerindo assim que a associação da angiogênese com a proliferação glial é 
responsável pela formação de novos vasos sanguíneos, participando assim da plasticidade associada ao comportamento motor (Li et al., 2005).

Uma das formas de verificar se o estriado é realmente ativado mediante a atividade motora é analisar a expressão de genes de indução imediata, já que estes estão presentes quando há atividade neuronal e de segundos mensageiros na célula (Morgan e Curran, 1991). Esta indução ocorre no estriado apenas se houver interação entre o glutamato e dopamina, pois os receptores de NMDA e de DA estão envolvidos na ativação do gene (Liste et al., 1995, 1997). Na atividade física há um aumento desta interação, visto que há um aumento nos níveis destes neurotransmissores (Hattori et al., 1994; Wheeler et al., 1995; Bland et al., 1999). A atividade em esteira é, assim, capaz de promover aumento da ativação de receptores de glutamato e dopamina, e consequentemente mudanças na expressão gênica (Liste et al., 1997).

\subsection{Neuroplasticidade}

O termo neuroplasticidade é definido por Roberto Lent como: "a propriedade do sistema nervoso de alterar a sua função ou a sua estrutura em resposta às influências ambientais que o atingem. Tanto as alterações plásticas quanto as influências ambientais que as provocam podem variar bastante, de muito forte a extremamente sutis" (Lent, 2008). Toda plasticidade depende então de atividade, podendo o estímulo ser interno ou externo.

A primeira descrição de plasticidade sináptica apareceu em 1973 pelos noruegueses Timothy Bliss e Terje LФmo, com a descoberta de sinapses hebbianas no hipocampo, sendo estas regulada pela atividade, responsável em sinalizar quais os fenômenos devem ocorrer no neurônio pós-sináptico tais como inserção ou remoção de receptores de glutamato da membrana ou se a conformação do canal iônico deve ser alterada (Genoux e Montgomery, 2007). Assim, alguns estudos têm revelado os mecanismos intracelulares pelos quais o glutamato causa alterações na eficiência sináptica, transcrição gênica e morfologia neural (Hayashi, 1952 e Curtis et al., 1960 apud Meldrum,2000; Mayer e Westbrook, 1987; Kind e Neumann, 2001; Chan et al., 2002; Kew et al., 2005; Brockie et al., 2006; Nowicka, 2006). 
Diferentes formas de neuroplasticidade vêm sendo estudadas, dentre elas a participação dos receptores de glutamato no influxo de $\mathrm{Ca}^{2+}$ intracelular. Acredita-se que estes receptores sejam capazes de produzir uma rota sinapticamente ativa para entrada de $\mathrm{Ca}^{2+}$, tendo assim um papel modulatório na função sináptica em longo prazo. Observou-se ainda que após a entrada de $\mathrm{Ca}^{2+}$ pelos receptores do tipo AMPA nos neurônios do corno dorsal da medula espinal há um aumento na amplitude dos potenciais sinápticos por um período prolongado (Gu et al., 1996). Outra evidência de neuroplasticidade está relacionada às mudanças que ocorrem na expressão de GluR2 em diferentes situações, tais como o desenvolvimento, processos de aprendizagem, pós-lesão, isquemias ou administração de antipsicóticos, drogas de abuso ou corticosteróides (Chalmer e McCulloch, 1990; Pires et al., 1997; Tanaka et al., 2000; Griffith set al., 2008; Kindlundh-Högberg et al., 2008). Porém, ao alterar a expressão de GluR2 ocorre alteração de fluxo de $\mathrm{Ca}^{2+}$, cujo aumento do influxo é capaz de ativar proteases, fosfolipases e endonucleases, que por sua vez, geram radicais livres que destróem a membrana celular por peroxidação lipídica, podendo levar à morte celular (Tanaka et al., 2000; Meldrum, 2000).

Fenômenos que vêm sendo muito estudados nesse contexto são LTP e depressão de longa duração (LTD). A LTP é um aumento prolongado da magnitude da resposta sináptica de um neurônio, quando o neurônio pré-sináptico é estimulado por uma salva curta de alta frequência. Este é um fenômeno típico de sinapses excitatórias glutamatérgicas, que já foi demonstrado em diferentes regiões do SNC, tais como córtex cerebral (Bear e Kirkwood, 1993; Katz e Shatz, 1996; Wright et al., 2001) e hipocampo (Miyamoto, 2006; Harms et al., 2008; Chepkova et al., 2008), sendo mais bem explicado no hipocampo. O papel dos receptores do tipo AMPA neste fenômeno deve-se à ativação de receptores do tipo NMDA, que permitem a entrada de $\mathrm{Ca}^{2+}$ (Cotman e Monaghan, 1988). Este íon aciona vias de sinalização intracelular que envolve as cinases, responsáveis por ativar mecanismos que promovem a fosforilação e inserção de receptores do tipo AMPA na membrana póssináptica (Sanes e Lichtman, 1999; Miyamoto, 2006). No entanto, a curto prazo, quanto maior a liberação de glutamato maior o número de receptores ativados, sendo papel do gás óxido nítrico (NO) liberado pelo neurônio pós-sináptico (após a despolarização e ativação de proteínas cinases) sinalizar ao neurônio pré-sináptico 
para aumentar a produção e liberação de glutamato na fenda sináptica, agindo assim como um mensageiro retrógrado (Garthwaite, 1991; Flora Filho e Zilberstein, 2000; Qiu e Knöpfel, 2007)(Figura 11).

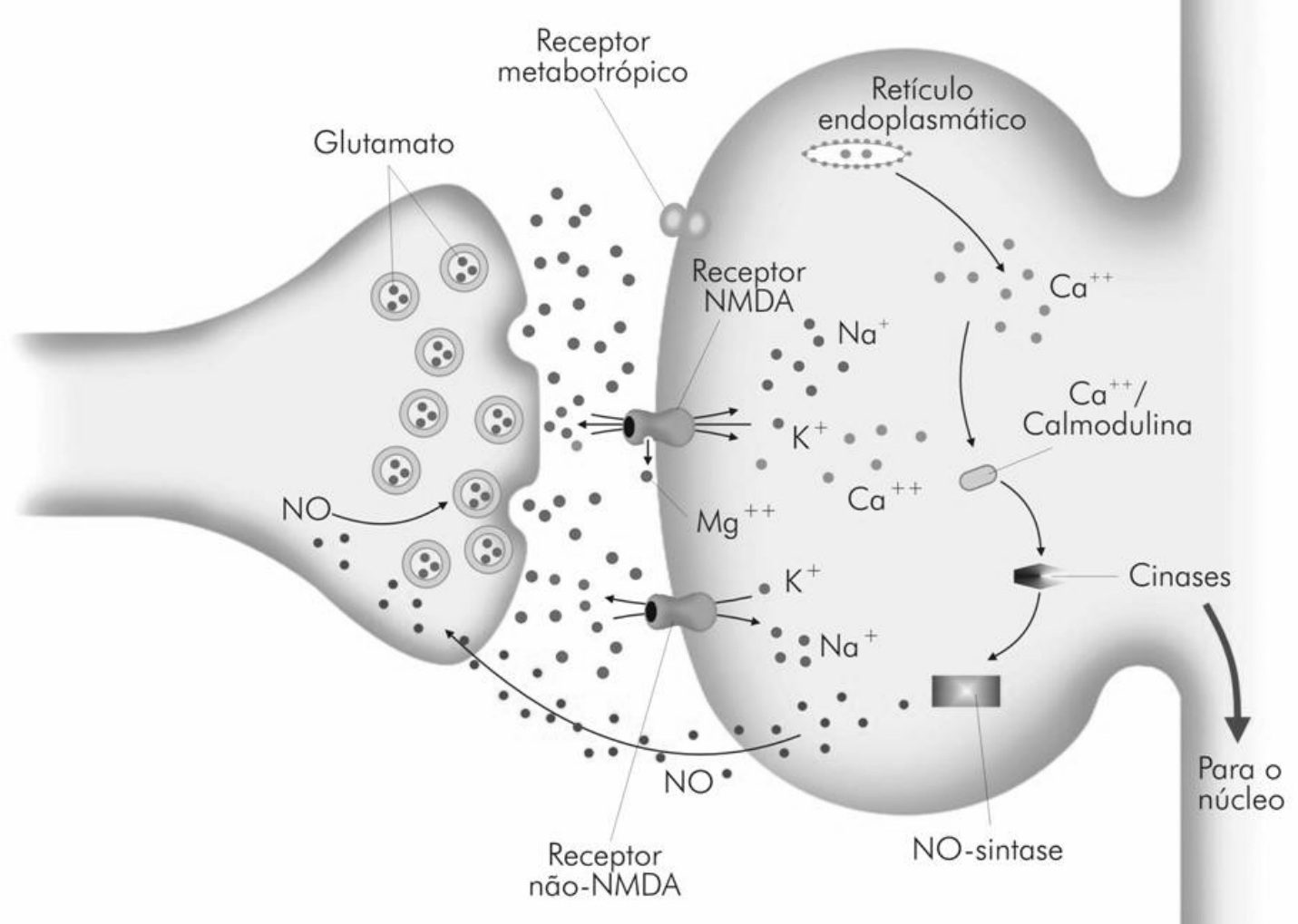

Figura 11. O mecanismo molecular da LTP envolve três receptores glutamatérgicos. O primeiro a ser ativado é o receptor AMPA, que se abre aos cátions e despolariza a membrana. A despolarização remove $\circ \mathrm{Mg}^{++}$do receptor NMDA, e mais cátions atravessam a membrana, acentuando a despolarização. $O$ terceiro receptor, metabotrópico, ativa uma cadeia de reações intracelulares que acabam por liberar íons $\mathrm{Ca}^{++}$para o citosol. $\mathrm{O}$ efeito despolarizante se prolonga ainda mais com a entrada e ação da NO-sintase, que produz óxido nítrico, um gás que atravessa livremente as membranas e acaba fazendo com que mais glutamato seja liberado pelo terminal pré-sináptico. Modificado de Lent (2005).

Os mecanismos de longo prazo que alteram a expressão gênica vêm sendo estudados desde sua descoberta, e assim mais de 100 moléculas já foram descritas como participantes destes mecanismos (Sanes e Lichtman, 1999). Estudos envolvidos com as bases moleculares da neuroplasticidade apontam as mudanças na adenosina monofosfato cíclico (AMPc) e proteína quinase A (PKA) como os principais responsáveis por promover mudanças na composição dos receptores de glutamato e na cinética dos receptores pós-sinápticos, promovendo assim inserção 
de receptores da membrana. Hu et al. (2009) demonstraram que o exercício voluntário é capaz de aumentar os níveis de proteínas pré e pós-sinápticas, tais como SNAP25 e PSD-95. O estado de fosforilação da PKA presente na subunidade GluR1 depende da ação do AMPc sobre a proteína. Com ação do AMPc ocorre mudanças na condutância dos receptores do tipo AMPA envolvidos na LTP hipocampal (Banke et al., 2000; Ehlers, 2000; Lee et al., 2000; Miyamoto, 2006), além de alterar a condutância nos receptores do tipo NMDA (Westphal et al., 1999). Estudos de Guire et al. (2008) mostraram a participação de calmodulina-dependente de proteína quinase I (CaM-Kinase I) no recrutamento de receptores do tipo AMPA. Há também um aumento da CaM-Kinase II durante a LTP, que é ativada com o aumento de complexos $\mathrm{Ca}^{2+} /$ calmodulina (CaM); o efeito pode ser visto inicialmente após 3 minutos de estimulação e manter-se por até uma hora. Além do aumento da CaM-Kinase II, há aumento da autofosforilação de suas subunidades $\alpha$ e $\beta$ (Fukunaga et al., 1995; Moriguchi et al., 2008). Há ainda aumento na fase inicial, e queda após 10 minutos, de MAPK (mitogen-activated protein kinase) e CaM Kinase IV, responsáveis por aumentar gradativamente a fosforilação de CREB (cAMP response element-binding) que atua na mudança da expressão gênica que ocorre na LTP (Miyamoto, 2006).

Outros moduladores da LTP são os fatores neurotróficos, que estão aumentados com o exercício físico (Molteni et al., 2002), pois a expressão gênica destes, principalmente do BDNF, é regulada por aferências glutamatérgicas, que se encontram aumentadas (Zafra et al., 1991). Os fatores neurotróficos promovem aumento da fosforilação de NR2B (Lin et al., 1998), e ativam mecanismos póssinápticos dependentes de fosforilação no hipocampo, promovendo correntes excitatórias pós-sinápticas (Dingledine et al., 1999). Para ocorrer LTP, deve haver expressão de NR2A e NR2B; a diminuição destas subunidades promove diminuição da LTP, como foi demonstrado em CA1 e CA3 do hipocampo de animais knockout (Sprengel et al., 1998). Estudo de Philpot et al. (2001) demonstrou que a experiência visual, devido à dominância ocular, promove aumento da expressão de NR2A, sendo capaz de diminuir a duração das respostas pós-sinápticas do receptor NMDA (Philpot et al., 2001).

A LTD, descrita pela primeira vez por Masao Ito (1986), é considerada o inverso da LTP, sendo mais bem descrita no cerebelo, em células de Purkinje, tendo 
característica associativa, pois deve ocorrer ativação simultânea das duas vias aferentes do sistema, fibras paralelas e trepadeiras. Ocorre também no hipocampo, nas sinapses dos colaterais de Schaeffer com os neurônios piramidais de CA1, e no córtex cerebral. LTD ocorre quando há uma estimulação repetitiva de baixa frequência dos terminais pré-sinápticos, e consequentemente depressão do potencial pós-sináptico. Neste caso, ao invés de ocorrer ativação de enzimas responsáveis pela fosforilação de receptores, ocorre ativação de fosfatases dependentes de $\mathrm{Ca}^{2+}$. As fosfatases são enzimas que promovem desfosforilação de receptores, e desta forma há a retirada de receptores do tipo AMPA da membrana, por endocitose. A sensibilidade da membrana pós-sináptica é diminuída e, então há depressão da resposta.

Diferentes estudos foram realizados para analisar os benefícios obtidos com 0 exercício envolvendo o receptor do tipo NMDA, e foi demonstrada uma participação desse receptor no aumento da neurogênese (Kitamura et al., 2003), facilitação da LTP (Van Praag et al., 1999) ou mudanças na LTD (Philpot et al., 2001), papel primordial na plasticidade sináptica do hipocampo por permitir despolarização mais rápida (Vaynman et al., 2003) e aumento de sua ativação via receptores do tipo AMPA que também estão aumentados (Dietrich et al., 2005), ou mesmo por ativar PKA, segundo mensageiro responsável pela regulação da atividade do receptor NMDA (Kind e Neumann, 2001). 


\section{JUSTIFICATIVA}

Os efeitos benéficos dos exercícios crônicos sobre o SNC são descritos por diversos autores. No entanto, os efeitos do exercício a curto prazo têm recebido menor enfoque. Diante dos benefícios desta modalidade em músculos e nervos, e da menor disponibilidade de estudos sobre os efeitos do exercício a curto prazo, a pesquisa das alterações centrais decorrentes destas práticas seria de grande relevância para a neurociência. Escolheram-se para o estudo os subtipos de receptores de glutamato do tipo AMPA, por esse ser o principal neuromediador excitatório do SNC e participar dos mecanismos de plasticidade sináptica como memória e aprendizado. 


\section{OBJETIVOS}

Avaliar as mudanças na expressão de subunidades de receptores de glutamato do tipo AMPA (GluR1 e GluR2/3), por serem as principais participantes nas alterações plásticas que ocorrem no sistema nervoso, em regiões do cerebelo, hipocampo, córtex motor e estriado de ratos após exercício físico agudo, pelos métodos de imuno-histoquímica e immunoblotting. Além disso, avaliar o possível envolvimento do estresse nas alterações encontradas no sistema nervoso através da dosagem dos níveis de corticosterona plasmática. 


\section{MATERIAL E MÉTODOS}

\subsection{Animais}

Foram utilizados nos experimentos 80 ratos machos da linhagem Wistar (200250g) fornecidos pelo biotério central do Instituto de Ciências Biomédicas da USP. Os animais foram mantidos em uma sala com ciclo invertido com temperatura constante de $23^{\circ} \mathrm{C}$ e ciclo claro/escuro artificialmente controlado de 12/12 h, tendo livre acesso à alimentação. Antes do início do treinamento físico os animais ficaram 15 dias na sala para adaptação de ciclo invertido (Salgado-Delgado et al., 2008; Campos et al., 2006). Este estudo foi conduzido de acordo com os Princípios Éticos de Experimentação Animal adotado pelo Colégio Brasileiro de Experimentação Animal (COBEA) e foi aprovado pela COMISSÃO DE ÉTICA EM EXPERIMENTAÇÃO ANIMAL (CEEA) do ICB/USP em 31/08/2007, protocolo registrado sob no 72 nas fls. 47 do livro 2 para uso de animais em experimentação.

\subsection{Protocolo de exercício}

O treinamento inicial consistiu de corrida em esteira durante 40 minutos a aproximadamente $75 \%$ do $\mathrm{VO}_{2}$ máximo (Lawler et al., 1993), considerado um treinamento de intensidade leve/moderada. O treino foi feito no período ativo do animal (Holmes et al., 2004). Os animais foram adaptados ao exercício por 15 minutos durante 2 dias, sendo iniciado a uma velocidade de 0,3 km/h com incrementos de velocidade da esteira de $0,1 \mathrm{~km} / \mathrm{h}$ a cada 5 minutos. Desta forma, ao fim do treino, os animais estavam a uma velocidade de $0,5 \mathrm{~km} / \mathrm{h}$, e neste período os animais que se recusaram a correr foram excluídos do protocolo.

O protocolo foi iniciado a $0,4 \mathrm{~km} / \mathrm{h}$ com incrementos da velocidade da esteira de $0,1 \mathrm{~km} / \mathrm{h}$ a cada 1 minuto, apenas para o aumento da velocidade ser gradativo. Assim, com 2 minutos a velocidade era de $0,6 \mathrm{~km} / \mathrm{h}$, velocidade na qual o animal correu por 38 minutos, percorrendo assim uma distância de aproximadamente 
395m/dia. O horário de início do treinamento foi o mesmo para todos os grupos, ou seja, entre 11-13h, acontecendo no período ativo do animal (Salgado-Delgado et al., 2008).

Os animais foram treinados em uma esteira ergométrica programável (KT 3000 - IMBRAMED) adaptada para ratos. A esteira era constituída de 10 raias de acrílico transparente pintadas de preto em sua extremidade anterior. A parte anterior mais escura das raias criava um ambiente para o qual os ratos eram atraídos durante o treinamento, evitando a necessidade de choques elétricos.

Os ratos Wistar foram divididos em 4 grupos: controle -animais não treinados, porém que "aceitaram" a corrida durante os dois dias de adaptação- (CONT), COR3 (animais treinados por 3 dias), COR7 (animais treinados por 7 dias) e COR15 (animais treinados por 15 dias). Os animais do grupo controle ficaram na caixa própria para ratos ao lado da esteira sem realizar atividade física, apenas sob efeito do barulho da esteira. Dos 80 animais, os encéfalos de 20 deles foram processados pelo método de imuno-histoquimica, os de 28 animais foram analisados pela técnica de immunoblotting e 32 foram usados para quantificação de corticosterona plasmática.

\subsection{Protocolo de imuno-histoquímica}

Os animais treinados e os controles, sendo $n=5$ para cada grupo, foram anestesiados e submetidos à perfusão transcardíaca, com solução salina 0,9\%, seguida de solução fixadora constituída de paraformaldeído $4 \%$ dissolvido em tampão fosfato $0,1 \mathrm{M}(\mathrm{PB}, \mathrm{pH} 7,4)$. Após a perfusão, os encéfalos foram coletados e armazenados em paraformaldeído $4 \%$, durante 4 horas. Após este período, 0 material foi transferido para uma solução crioprotetora de sacarose a $30 \%$ em PB. Após 24 horas, foram feitos cortes frontais dos encéfalos em uma espessura de 30 $\mu \mathrm{m}$ em um micrótomo deslizante de congelamento (Leica SM $2000 \mathrm{R}$ ). Os cortes foram submetidos à metodologia de imuno-histoquímica com anticorpos específicos para detecção das subunidades dos receptores do tipo AMPA. Os cortes histológicos foram colocados em placa de cultivo de 6 unidades, em tampão fosfato, 
mantidos em geladeira a $4{ }^{\circ} \mathrm{C}$ até $\mathrm{o}$ momento do procedimento de imunohistoquímica.

A realização da imuno-histoquímica se processou da seguinte forma: os cortes selecionados foram lavados em tampão fosfato (PB 0,1M) por três vezes de 10 minutos, em seguida foram incubados com anticorpos policlonais primários de coelho específicos contra as subunidades GluR1 (Chemicon-AB1504) em uma concentração de 1:250, GluR2/3 (Chemicon-AB1506) em uma concentração de 1:500, em PB com $0,3 \%$ de Triton X-100 por um período de 14 a 18 horas a temperatura ambiente.

Os cortes foram então novamente lavados em PB 0,1M em temperatura ambiente e incubados por duas horas com o anticorpo secundário marcado com biotina contra as imunoglobulinas de coelho. Após nova série de lavagens à temperatura ambiente, os tecidos foram colocados por duas horas numa solução de Triton X-100 0,3\% em tampão fosfato 0,1M com 0,4 M de $\mathrm{NaCl}$, onde se incluiu 0 complexo avidina-biotina-peroxidase (ABC ELITE kit, Vector Lab., Burlingame, CA, EUA). Após nova série de lavagens, os cortes foram imersos num meio contendo 33'diaminobenzidina (DAB-Sigma-Aldrich, Saint Louis, MO, EUA) 0,05\% em tampão fosfato $0,1 \mathrm{M}$ por cerca de 5 minutos. Acrescentaram-se algumas gotas de uma solução contendo $200 \mu \mathrm{L}$ de solução de peróxido de hidrogênio a 30\% diluídos em $10 \mathrm{~mL}$ de água destilada, mantendo-se os cortes neste banho até que a reação fosse evidenciada (cerca de 20 minutos). Atingida a imurreatividade desejada, os cortes foram removidos da solução com DAB e imersas em tampão. Depois de nova série de lavagens em tampão fosfato $0,1 \mathrm{M}$ com o objetivo de remoção do excesso de reagente, os cortes foram colocados sobre lâminas de vidro gelatinizadas e colocadas em placa quente, e ao secarem foram hidratados em água destilada por 1 minuto, banhadas em solução de tetróxido de ósmio 0,1\% por 15 - 30 segundos para intensificar a coloração, desidratadas por uma série de álcoois em concentrações crescentes, clareadas com Hemo-De (Fisher) e cobertos com lamínulas tendo como meio de montagem o Permount (Sigma). O material obtido foi analisado em microscópio óptico equipado em campo claro e campo escuro, e contraste de interferência diferencial (Normaski). Imagens digitais foram obtidas por meio de uma câmera de vídeo acoplada a um microscópio Nikon, e as Figuras 
representativas de cada grupo foram montadas no programa Adobe Photoshop (Adobe Systems Inc., Mountain View, CA, USA).

\subsection{Protocolo de immunoblotting}

Após o treino físico, 7 animais para cada grupo foram decapitados, e o córtex cerebral, cerebelo, hipocampo e estriado foram rapidamente coletados e homogeneizados a 4ํ em tampão de extração (Tris pH 7,4 100 mM; EDTA 10 mM; PMSF $2 \mathrm{mM}$; aprotinina $0,01 \mathrm{mg} / \mathrm{ml}$ ) com um homogenizador do tipo Turratec modelo MA-102/mini (Marconi; São Paulo, Brasil). Os homogenatos foram centrifugados a $12.000 \mathrm{rpm}$ por 20 minutos a $4^{\circ} \mathrm{C}$ em uma centrífuga modelo CT14000 DR (Cientec, São Paulo, Brasil). O conteúdo protéico do material isolado dos animais treinados e controles foi dosado pelo método de Bradford (Amresco, U.S.A)(Bradford, 1976). As amostras contendo as proteínas foram armazenadas em tampão Laemmli (Tris/HCl 125mM, pH 6,8, contendo 2,5\% (p/v) de SDS, 2,5\% de 2mercaptoetanol (2-ME), 4mM de EDTA e 0,05\% de azul de bromofenol) (Laemmli,

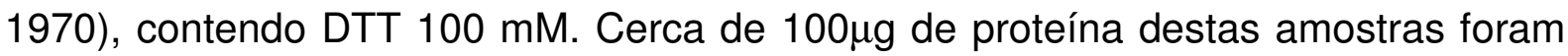
submetidas a eletroforese em gel de acrilamida a $8 \%$ contendo dodecil sulfato de sódio utilizando uma cuba para mini-gel (Mini-Protean 3; Bio-Rad). Após a separação eletroforética, as proteínas foram eletro-transferidas para a membrana de nitrocelulose utilizando-se um sistema de transferência (Trans-Blot cell system; BioRad), em tampão contendo SDS, de acordo com a técnica descrita por Towbin et al. (1979). Após a transferência, as membranas foram incubadas em solução de bloqueio com leite desnatado (Molico, Nestlé) a 5\% em tampão salina contendo Tween 20 (TTBS; 0,01 M de Tris- $\mathrm{HCl}, \mathrm{PH}$ 7,4, 0,15M de $\mathrm{NaCl}, 0,05 \%$ de Tween 20), por 2 horas em temperatura ambiente sob agitação leve. Após este período, as membranas foram lavadas por três vezes de 10 minutos com TTBS e incubadas com os anticorpos contra GluR1 e GluR2/3 (utilizados na imuno-histoquímica) na concentração de 1:1000, e beta-actina, na concentração 1:10000, em solução bloqueadora de albumina, por 18 horas a $4^{\circ} \mathrm{C}$, sob leve agitação. Em seguida, as membranas foram lavadas novamente e incubadas por 1 hora com o anticorpo secundário anti-coelho conjugado com peroxidase (Amersham; Little Chalfont, 
Buckinghamshire, UK) em temperatura ambiente, diluído a 1:10000 em solução bloqueadora, contendo $1 \%$ de leite desnatado em TTBS. Novo ciclo de lavagens da membrana foi realizado e a ligação específica do anticorpo com a proteína foi revelada utilizando o kit quimioluminescente ECL (Amersham Biosciences, NJ, EUA). Finalmente as bandas obtidas nos filmes foram escaneadas e analisadas quanto à densidade óptica da imunorreatividade usando-se o programa Scion Image (Scion Corporation, Frederick, MD, EUA). Dos dados obtidos realizou-se uma razão entre a densidade óptica das subunidades e da $\beta$-actina, e estes dados foram então submetidos às análises estatísticas com o programa Prisma4.

\subsection{Dosagem de Corticosterona no Plasma}

A dosagem da concentração de corticosterona no plasma é um dos métodos utilizados para analisar se o protocolo ao qual o animal está sendo submetido está promovendo estresse. Assim, realizamos esta dosagem para analisarmos se os efeitos encontrados sobre as subunidades estudadas são puramente do exercício em esteira ou se há um aumento nos níveis de cortisol. Logo, a concentração de corticosterona plasmática de ratos controles e treinados foi determinada usando o kit de ELISA (Caiman Chemical, EUA), de acordo com o método de Pradelles et al. (1985). Utilizaram-se 8 animais por grupo. Os animais foram decapitados para coleta do sangue em tubos vacutainers contendo heparina sódica às 13horas, logo após 0 treino físico. Os tubos foram centrifugados à $1000 \times \mathrm{xg}$ por 15 minutos a $4^{\circ} \mathrm{C}$ para separação do plasma, o qual foi estocado em eppendorfs à $-80^{\circ} \mathrm{C}$. As amostras foram diluídas (1:10), e então, incubadas por 2 horas em temperatura ambiente com corticosterona conjugada com acetilcolinesterase e com o antisoro específico em uma placa de 96 poços pré-cobertos com o anticorpo anti-imunoglobulina $G$ de coelho. Após a incubação, as placas foram lavadas, e foi adicionado um substrato enzimático (reagente de Ellman). A densidade óptica das amostras foi determinada após aproximadamente 1 hora em leitor de Elisa $(412 \mathrm{~nm})$ e a concentração de corticosterona foi calculada utilizando-se uma curva padrão. 


\subsection{Pesagem das Adrenais}

Outra forma de análise do estresse do animal é a pesagem das glândulas adrenais, pois quando sua atividade está muito aumentada e por um longo período de tempo essa glândula pode sofrer alteração em seu peso. Após a decapitação dos animais para coleta do sangue, estes foram abertos pelo abdômen e as adrenais de todos os grupos foram dissecadas para serem pesadas em balança de precisão (Marte Balanças e Equipamentos Modelo AL 500).

\subsection{Análise Estatística}

Os dados de immunoblotting e dosagem de corticosterona apresentaram uma distribuição normal segundo o teste de Kolmogorov-Smirnov. As medidas de tendência central (média) e dispersão da amostra (desvio-padrão) estão apresentadas no gráfico dos resultados. Para comparações entre os grupos utilizouse o programa de computador (Prisma4) com análise de variância (ANOVA) para medidas não-repetidas, seguida do pós-teste de Bonferroni quando a análise de variância apresentou diferença estatisticamente significante. Para todos os testes, o nível de significância assumido foi de $p \leq 0,05$. 


\section{RESULTADOS}

Os resultados do immunobloting corroboram em geral os dados obtidos na imuno-histoquímica, porém vale lembrar que a técnica de immunoblotting analisa o conteúdo protéico de toda a estrutura removida do encéfalo, inclusive os núcleos cerebelares, por exemplo, que não foram analisados na imuno-histoquímica, além de permitir que o epítopo reconhecido pelo anticorpo esteja mais exposto. Além disso, o immunoblotting tem como resultado final um material que permite uma análise quantitativa da densidade óptica, enquanto a imuno-histoquímica permite uma análise dos tipos e localização das estruturas imunorreativas, e uma análise subjetiva de intensidade de marcação como por exemplo, aumento ou diminuição.

As subunidades GluR1 e GluR2/3 dos receptores de glutamato do tipo AMPA, que serão referidas como subunidades neste estudo, são expressas pelas células de todas as estruturas estudadas. Nossos resultados demonstraram também que a subunidade GluR1 respondeu de forma distinta a GluR2/3 em função do exercício físico, sofrendo maiores alterações entre os grupos. Assim, para apresentação dos nossos dados iremos dividí-los em GluR1 e GluR2/3, e por região estudada, sendo elas: córtex motor primário (M1), córtex motor secundário (M2), estriado (CPu), giro denteado (GD) e córtex cerebelar (Cb).

De forma geral, os dados do immunoblotting neste estudo coincidem com os da imuno-histoquímica, exceto no estriado, onde a expressão de GluR1 no décimo quinto dia de corrida apresentou acréscimo de $90 \%$ no immunoblotting, não evidente na imuno-histoquímica. No $\mathrm{M} 1, \mathrm{M} 2$ e $\mathrm{Cpu}$, as subunidades GluR2/3 são mais expressas do que GluR1. Já no hipocampo GluR1 é mais expressa do que GluR2/3. No cerebelo as subunidades GluR1 e GluR2/3 mostraram um padrão semelhante de expressão. 


\subsection{GluR1}

No $\mathrm{Cb}$ (Figura 12) apenas as Células de Purkinje (CP) e neurópila da camada molecular são GluR1-positivas. Com o treino de 3 dias, há uma diminuição na intensidade de marcação nas $\mathrm{CP}$, sem alteração da marcação da neurópila. Em COR7 e COR15 as CP expressam a mesma intensidade do CONT, enquanto a neurópila da camada molecular apresenta intensificações da imunorreatividade (Figura 13) (Tabela 1).

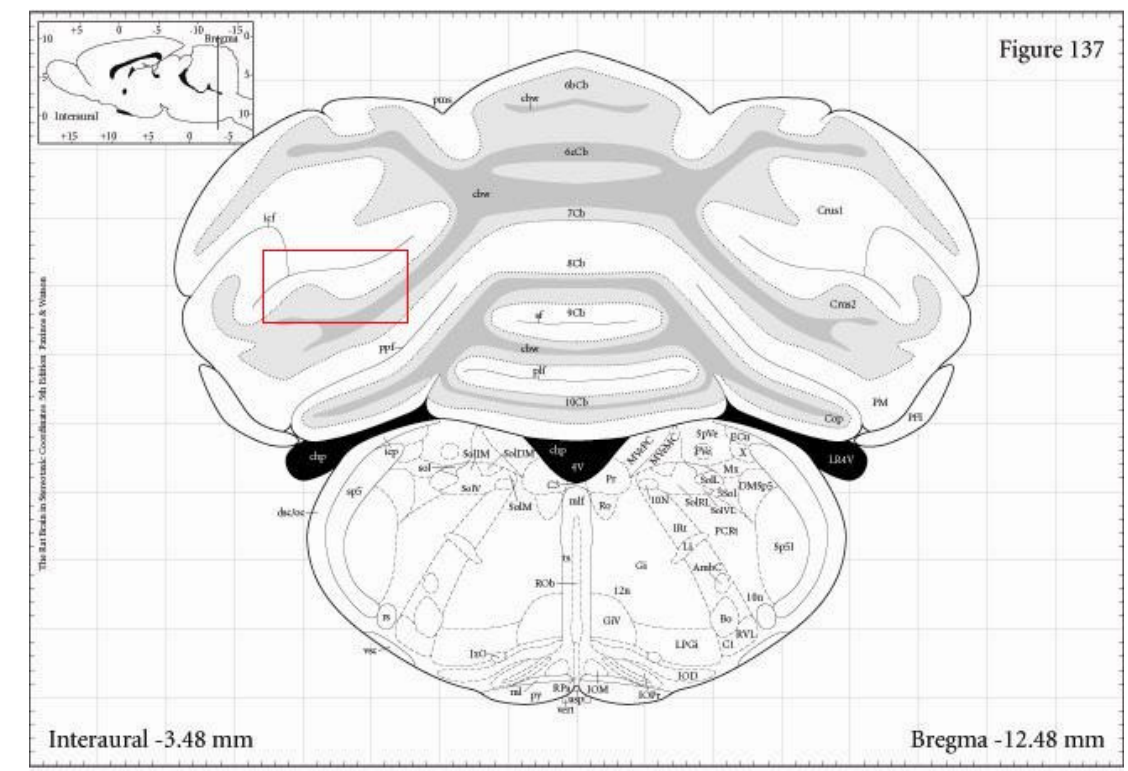

Figura 12. Esquema llustrativo do encéfalo de ratos destacando a região do córtex cerebelar.

Imagem obtida de: "THE RAT BRAIN - IN STEREOTAXIC COORDINATES - George Paxinos e Charles Watson". Elsevier Academic Press, 2005.

Os dados de immunoblotting referem-se a todas as estruturas do cerebelo, tais como os núcleos profundos e córtex cerebelar. A análise dos resultados demonstrou uma tendência à queda em $\operatorname{COR} 3(0,71 \pm 0,02$; não estatísitico $(\mathrm{n} / \mathrm{s}))$, seguido de aparente acréscimo de $23 \%$ em relação ao CONT $(0,86 \pm 0,10)$ em COR7 $(1,06 \pm 0,11 ; \mathrm{n} / \mathrm{s})$, retornando à expressão do CONT em COR15 $(0,89 \pm 0,13)$ (Figura $14)$. 

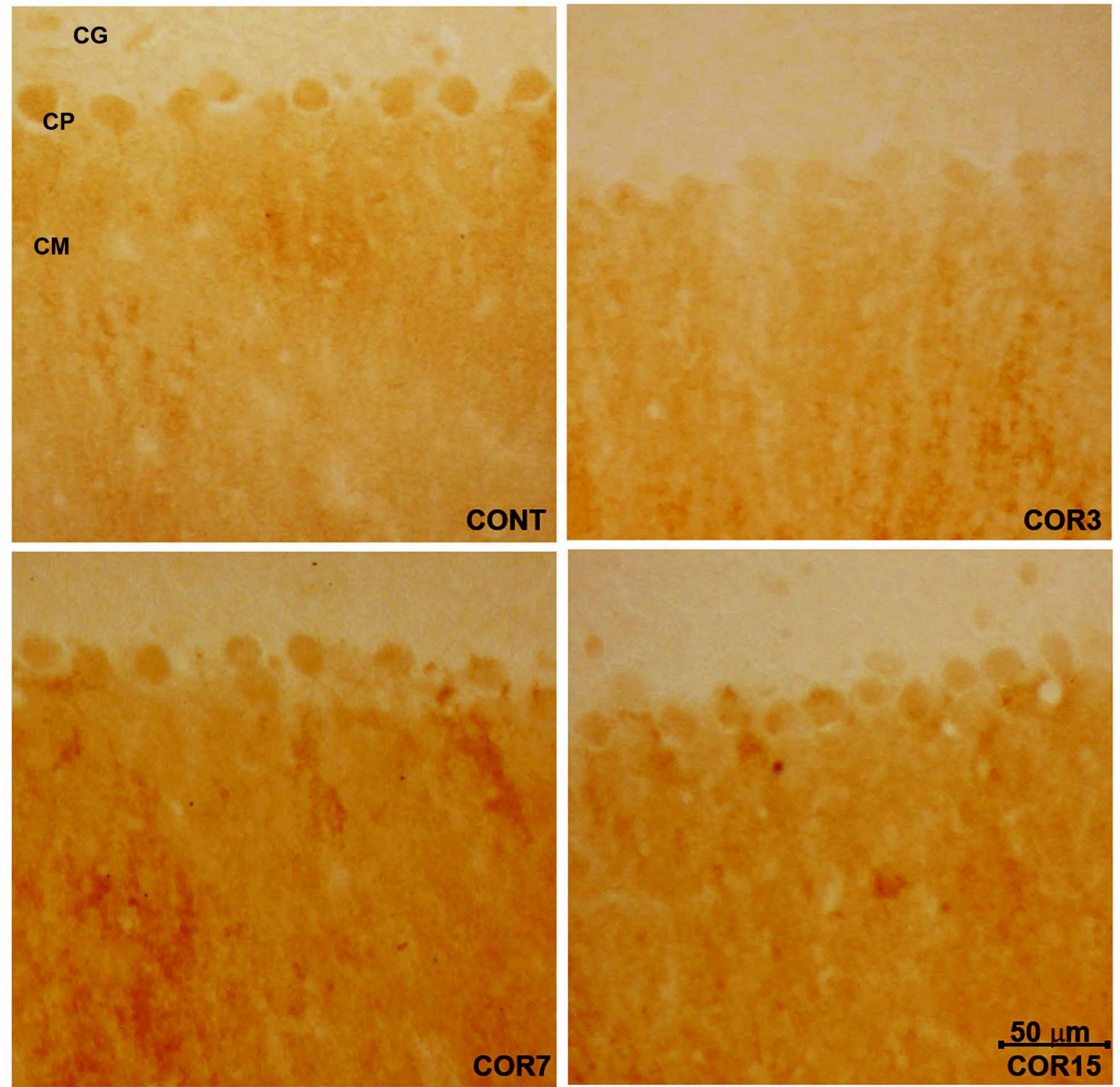

Figura 13. Imagens digitais de corte frontal do encéfalo de rato ilustrando a expressão da subunidade GluR1 no córtex cerebelar (camada granular - CG; camada de células de purkinje - CP; e camada molecular - CM) no animal controle (CONT) e animais experimentais que correram na esteira por 3, 7 e 15 dias (COR3, COR7 e COR15, respectivamente). Note uma diminuição na expressão em COR3, voltando ao padrão de marcação mais próximo do CONT em COR7 e COR15. Escala $=50 \mu \mathrm{m}$. 
C

A

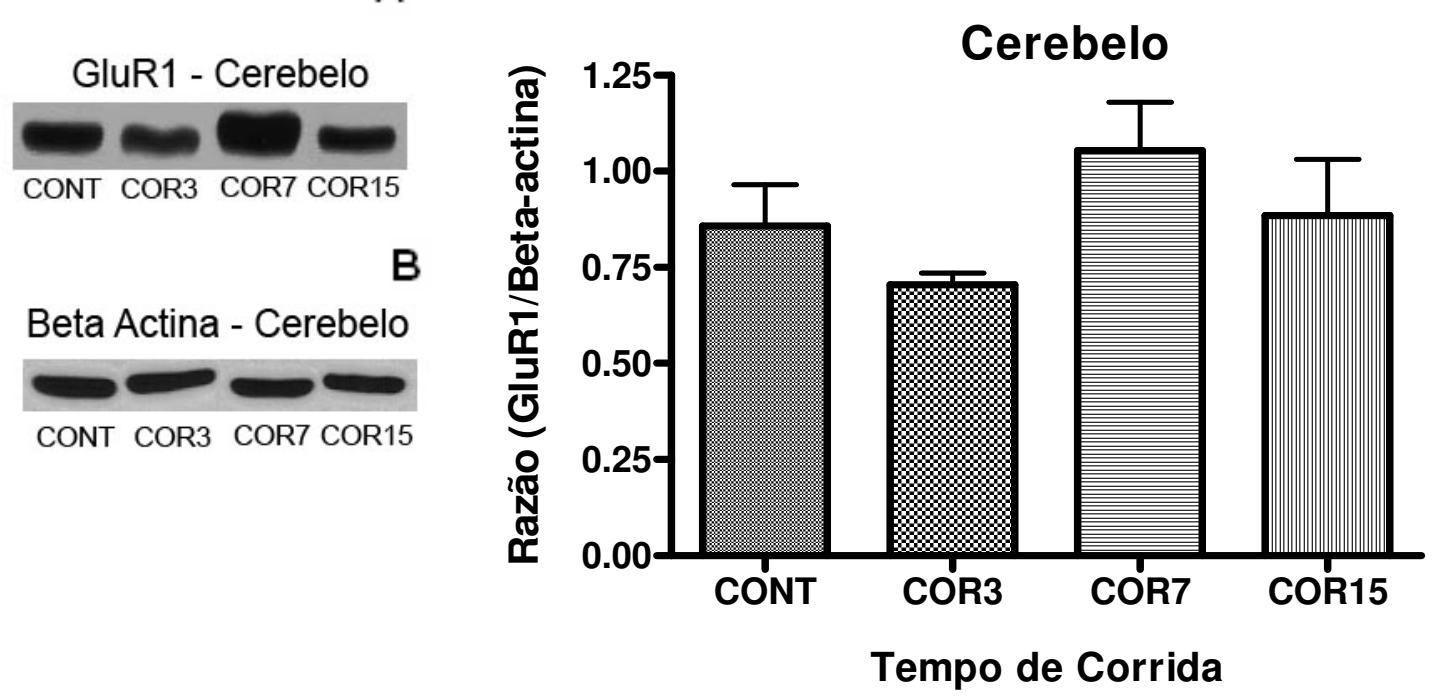

Figura 14. Efeitos do exercício na expressão da subunidade GluR1 do receptor de glutamato do tipo AMPA no cerebelo de ratos, avaliado por immunoblotting. A - Immunoblots de GluR1 do cerebelo dos animais controle (CONT) e que correram por 3 dias (COR 3), 7 dias (COR7) e 15 dias (COR15). B - controle com $\beta$-actina das amostras de A. C - Razão da densidade óptica da expressão de GluR1 e $\beta$-actina, demonstrando as diferenças nos grupos estudados. A razão da densidade óptica GluR1/ $\beta$-actina não foi estatisticamente significante em nenhum grupo quando comparado ao controle.

No GD dos animais controle (Figura 15) observou-se imunorreatividade para GluR1 em neurópila da camada molecular e polimórfica, e células da camada polimórfica, que podem ser células musgosas, principal célula desta região. Em COR3 parece haver uma pequena diminuição da intensidade de marcação em toda a estrutura, enquanto em COR7 há uma intensificação na marcação celular e aumento da arborização dendrítica, além de surgirem células marcadas na camada granular. Em COR15, volta a não haver marcação em células da camada granular, além de uma pequena diminuição da imunorreatividade celular, porém a arborização da camada polimórfica continua com maior intensidade do que no CONT (Figura 16) (Tabela 1). 


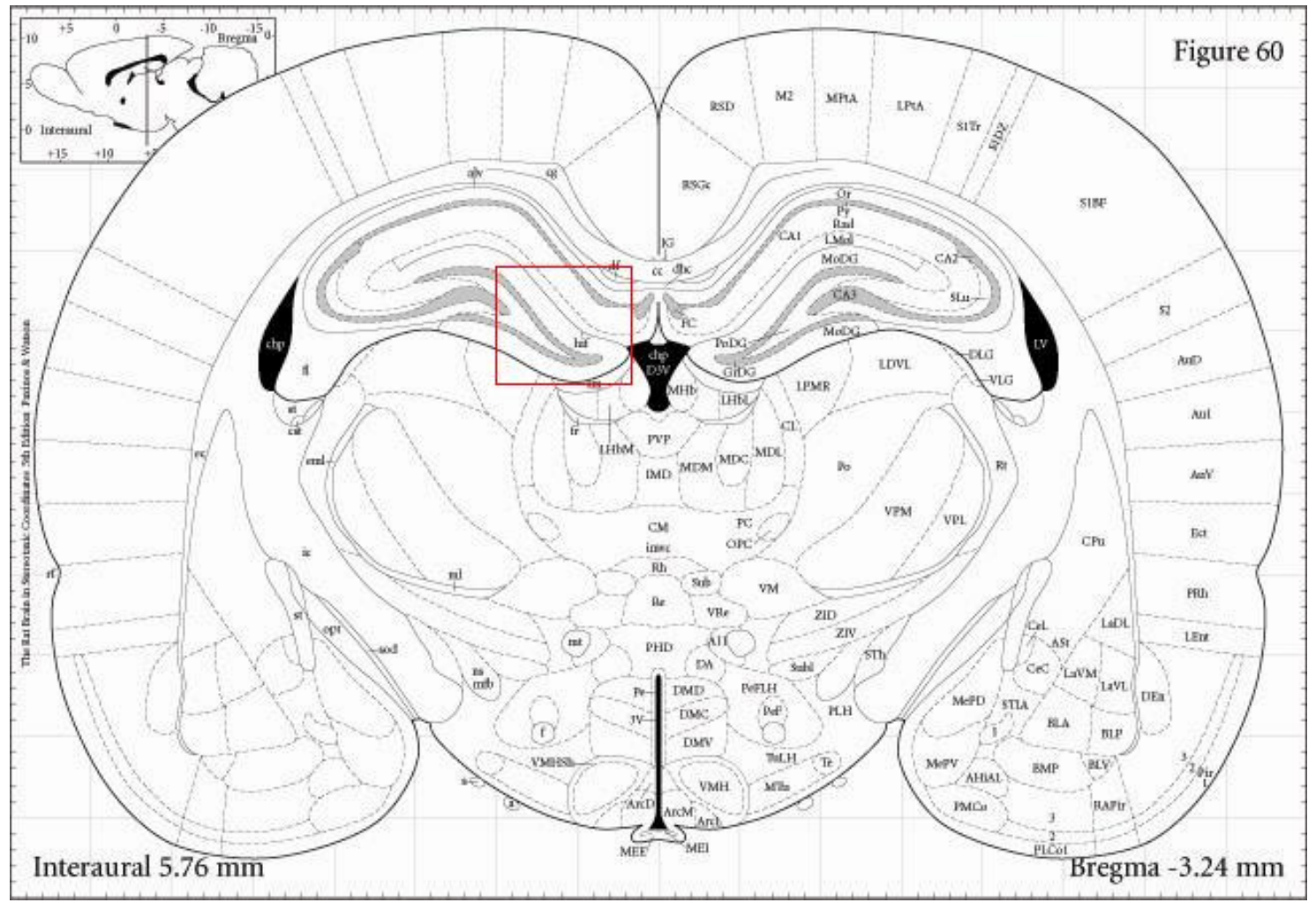

Figura 15. Esquema llustrativo do encéfalo de ratos destacando a região do giro denteado. Imagem obtida de: "THE RAT BRAIN - IN STEREOTAXIC COORDINATES - George Paxinos e Charles Watson". Elsevier Academic Press, 2005.

A análise do immunoblotting é referente a todo o hipocampo, ou seja, CA1CA4 e GD, porém os resultados corroboram a análise qualitativa realizada na imunohistoquímica, revelando queda de $40 \%$ no $\operatorname{COR} 3(0,76 \pm 0,13 ; p<0,05)$ em relação ao CONT $(1,23 \pm 0,34)$, retornando ao padrão de marcação do CONT em COR7 $(1,30 \pm 0,28)$, com nova aparente queda, não significante, de $14 \%$ em COR15 $(1,08 \pm 0,29 ; \mathrm{n} / \mathrm{s})$ (Figura 17). 

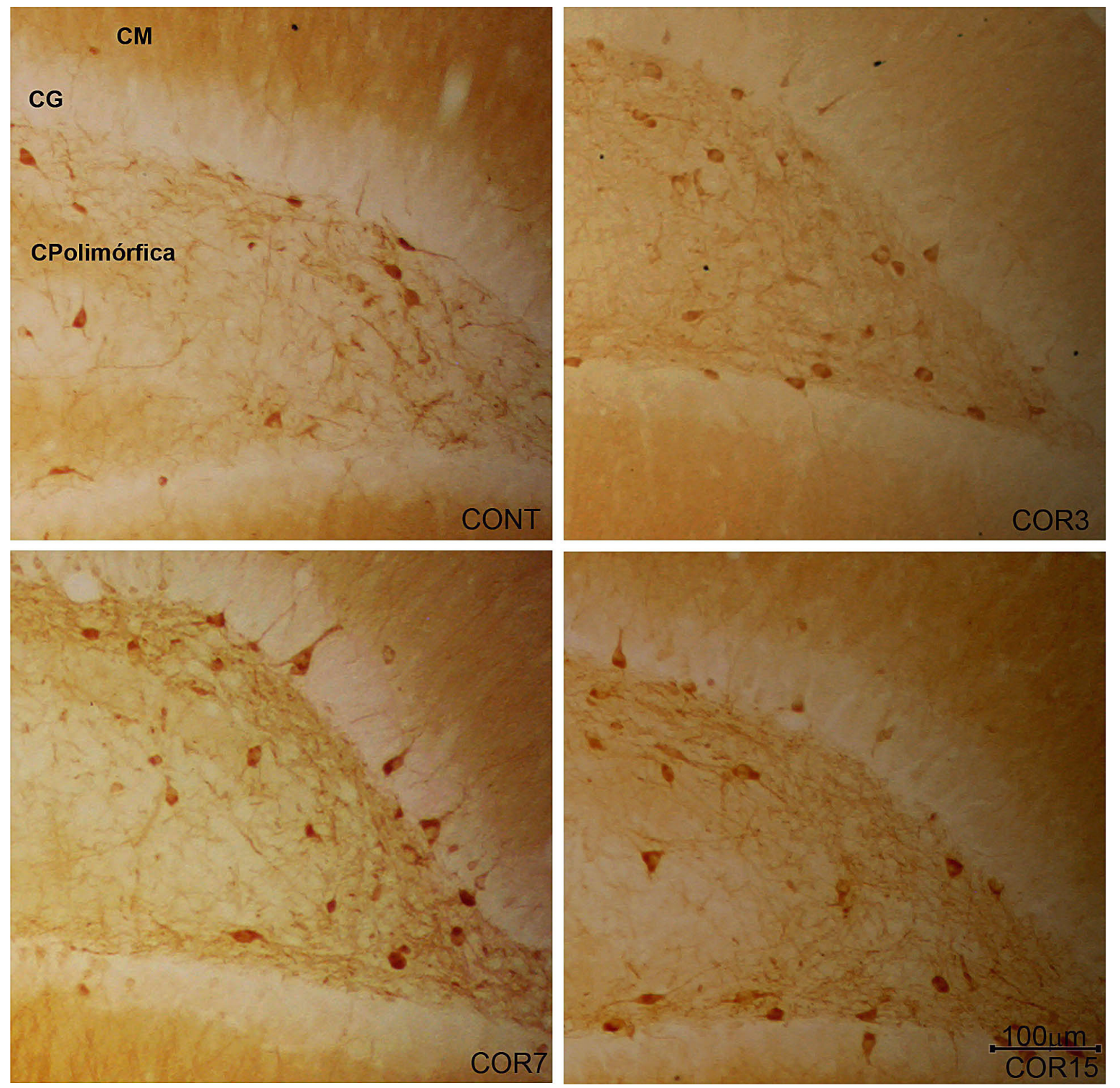

Figura 16. Imagens digitais de corte frontal do encéfalo de rato ilustrando a expressão da subunidade GluR1 no giro denteado (camada molecular - CM; camada granular - CG; e camada de células polimórficas - CP) no animal controle (CONT) e animais experimentais que correram na esteira por 3, 7 e 15 dias (COR3, COR7 e COR15, respectivamente). Note uma diminuição na intensidade da marcação em COR3 e um aumento em COR7 e COR15. Escala $=100 \mu \mathrm{m}$. 

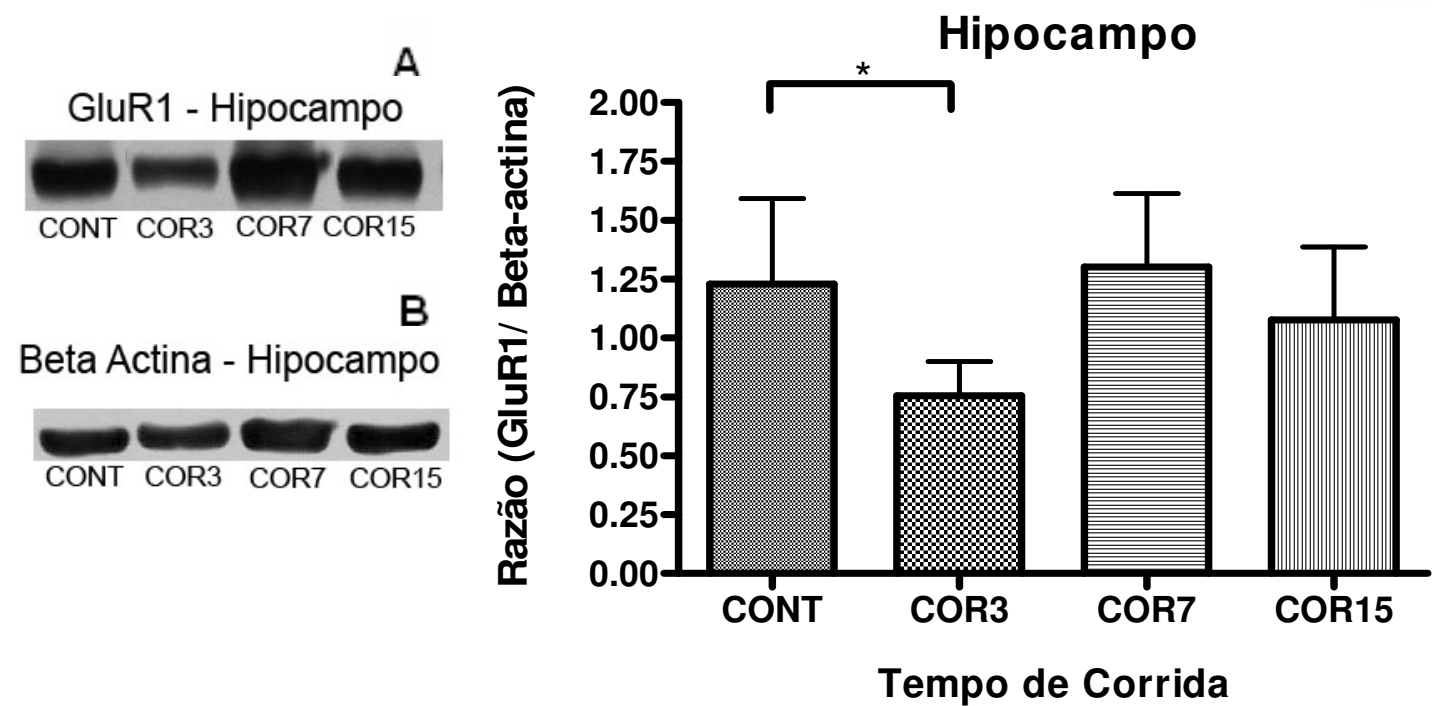

Figura 17. Efeitos do exercício na expressão da subunidade GluR1 do receptor de glutamato do tipo AMPA no hipocampo de ratos, avaliados por immunoblotting. A - Immunoblots de GluR1 do hipocampo dos animais controle (CONT), e que correram por 3 dias (COR 3), 7 dias (COR7) e 15 dias (COR15). B - controle com $\beta$-actina das amostras de A. C - Razão da densidade óptica da expressão de GluR1 e $\beta$-actina, demonstrando as diferenças nos grupos estudados. A razão da densidade óptica GluR1/ $\beta$-actina foi estatisticamente significante em COR3 ( $\left.{ }^{*} p<0,05\right)$.

A subunidade GluR1 é expressa em diferentes células do córtex cerebral, porém em nosso estudo analisamos a camada $V$ do córtex motor primário e secundário, por ser a principal via eferente do sistema (Figura 18). Nos animais CONT houve imunorreatividade em células piramidais e de arborizações dendríticas dispersas em toda a camada tanto em M1 como em M2; nos animais experimentais, após 3 e 7 dias de corrida, houve diminuição da intensidade, principalmente na arborização; em COR15 o corpo celular assume marcação semelhante ao CONT, porém a marcação na arborização continua diminuída, apesar de um pouco mais intensa do que em COR3 e COR7 (Figuras 19 e 20) (Tabela 1). 


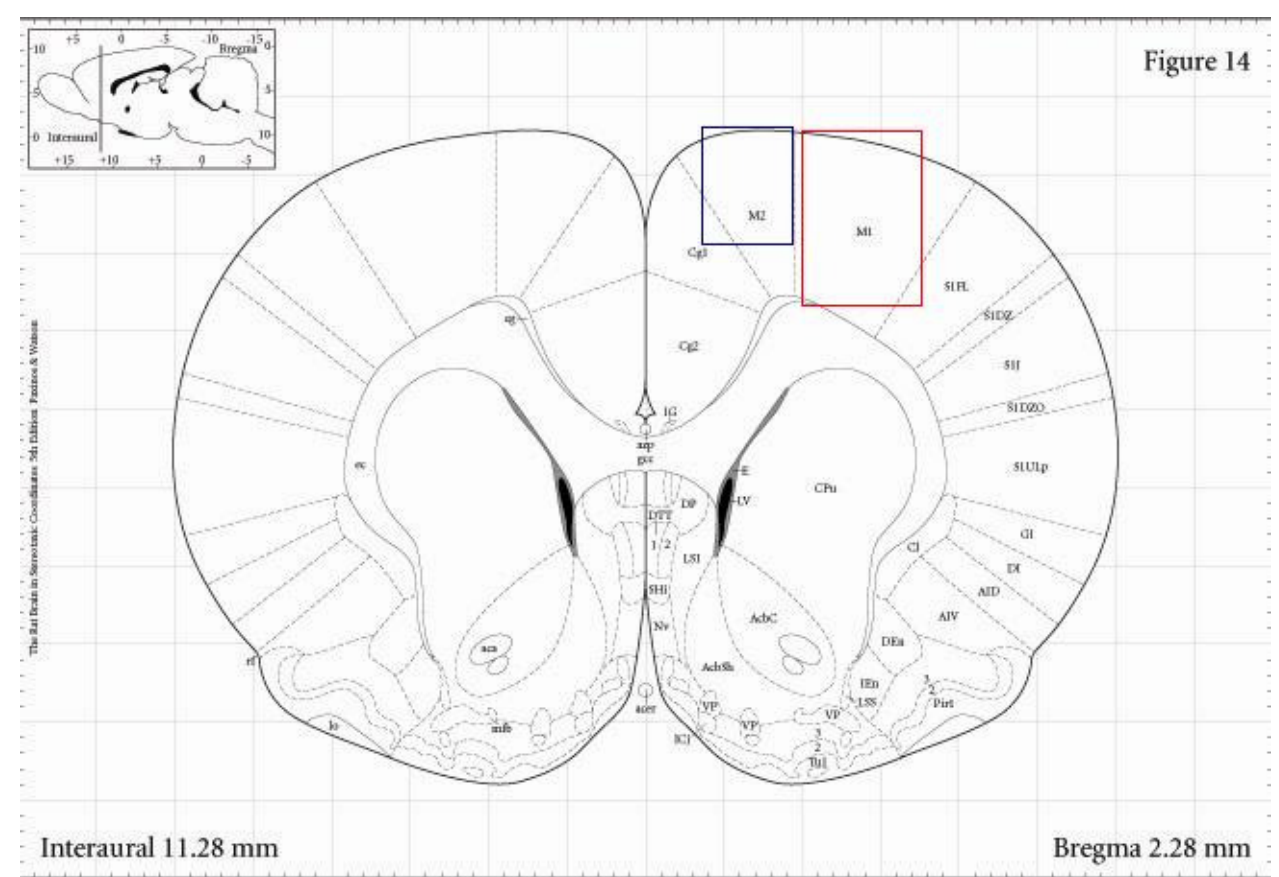

Figura 18. Esquema llustrativo do encéfalo de ratos destacando a região estudada do córtex motor primário (M1-vermelho) e secundário (M2-azul). Imagem obtida de: "THE RAT BRAIN IN STEREOTAXIC COORDINATES - George Paxinos e Charles Watson". Elsevier Academic Press, 2005.

Os dados de immunoblotting do córtex cerebral (córtex motor e sensorial) corroboram os da imuno-histoquímica, revelando uma queda na expressão da subunidade GluR1 em relação ao CONT $(0,82 \pm 0,12)$ de $40 \%$ em COR3 $(0,49 \pm 0,23$, $p<0,05), 52 \%$ em COR7 $(0,39 \pm 0,19, p<0,01)$ e tendência a queda em COR15 $(18 \%$, $0,66 \pm 0,14, \mathrm{n} / \mathrm{s})($ Figura 21). 

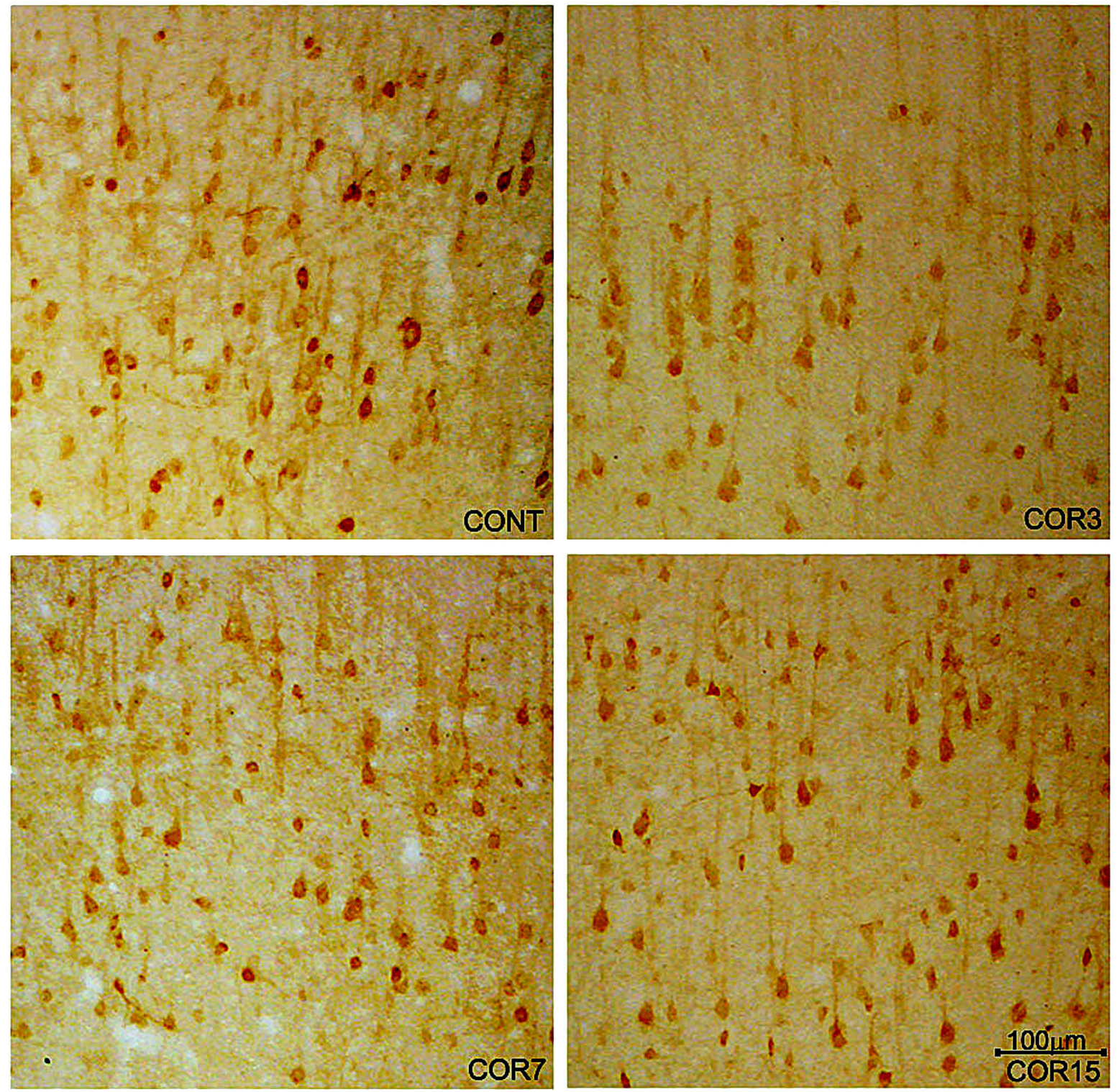

Figura 19. Imagens digitais de corte frontal do encéfalo de rato ilustrando a expressão da subunidade GluR1 na camada $V$ do córtex motor primário no animal controle (CONT) e animais experimentais que correram na esteira por 3, 7 e 15 dias (COR3, COR7 e COR15, respectivamente). Note uma diminuição de expressão em COR3 e COR7, voltando ao padrão de marcação mais próximo do CONT em COR15. Escala $=100 \mu \mathrm{m}$. 

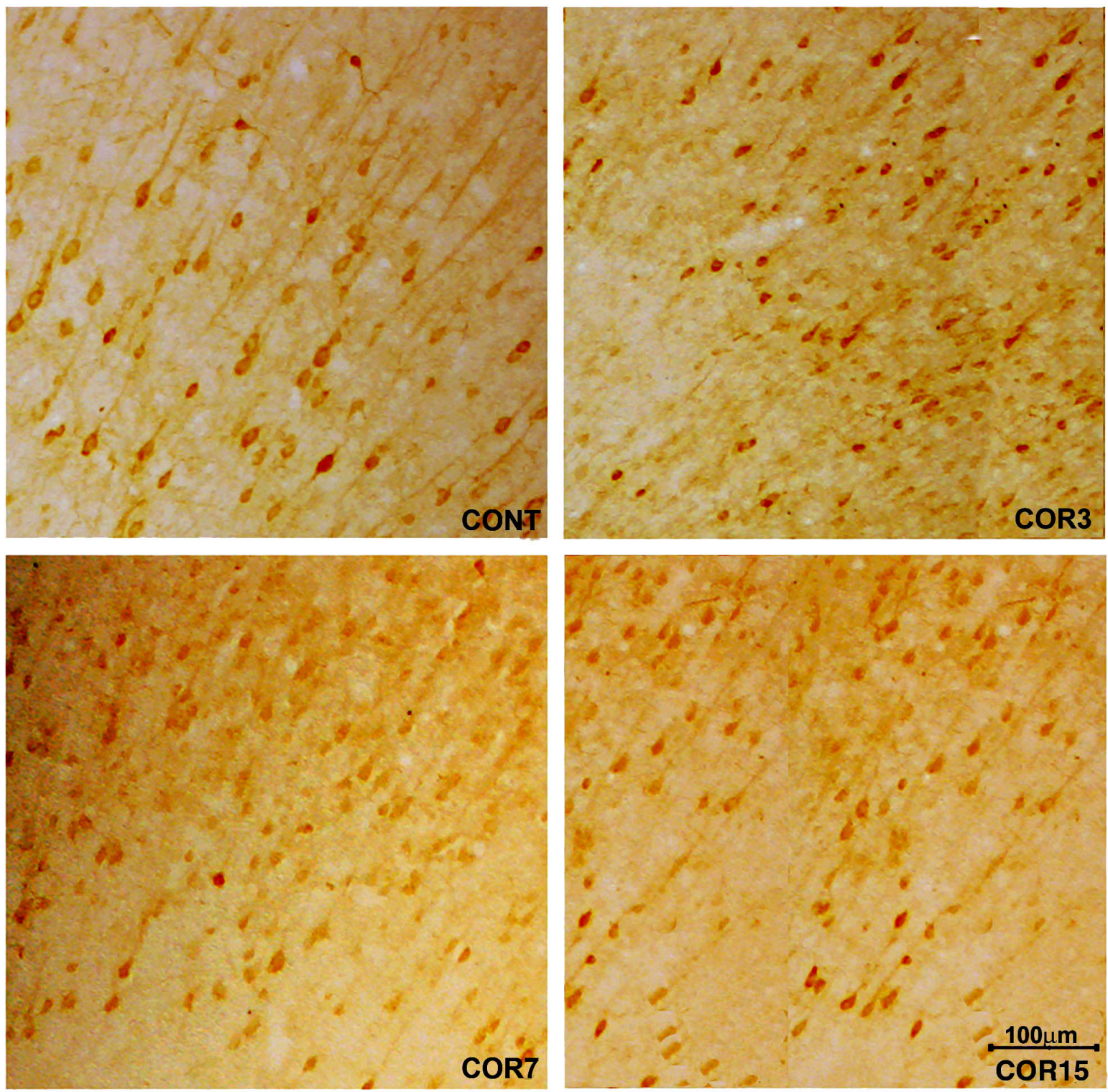

Figura 20. Imagens digitais de corte frontal do encéfalo de rato ilustrando a expressão da subunidade GluR1 na camada $V$ do córtex motor secundário no animal controle (CONT) e animais experimentais que correram na esteira por 3, 7 e 15 dias (COR3, COR7 e COR15, respectivamente). Note uma diminuição da expressão em COR3 e COR7, sendo maior em COR7, voltando ao padrão de marcação mais próximo do CONT em COR15. Escala $=100 \mu \mathrm{m}$. 


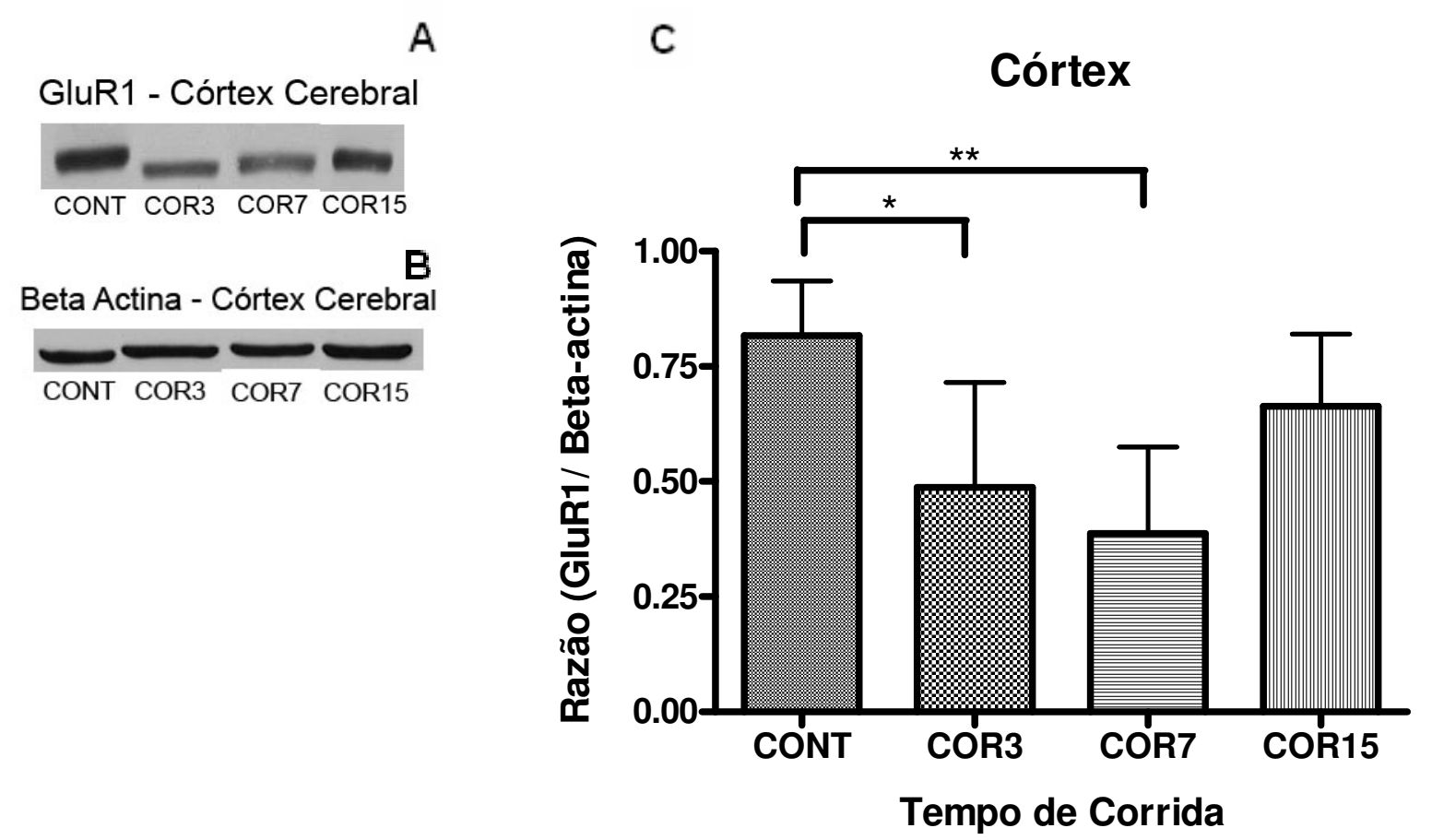

Figura 21. Efeitos do exercício na expressão da subunidade GluR1 do receptor de glutamato do tipo AMPA no córtex cerebral de ratos, avaliados por immunoblotting. A - Immunoblots de GluR1 do Córtex Cerebral dos animais controle (CONT), e que correram por 3 dias (COR 3), 7 dias (COR7) e 15 dias (COR15). B - controle com $\beta$-actina das amostras de A. C Razão da densidade óptica da expressão de GluR1 e $\beta$-actina, demonstrando as diferenças nos grupos estudados. A razão da densidade óptica GluR1/ $\beta$-actina foi estatisticamente significante após 3 dias $\left({ }^{*} p<0,05\right)$ e 7 dias $\left({ }^{* *} p<0,01\right)$.

Nos núcleos caudado e putâmen (Figura 22) houve marcação em corpos celulares arredondados, e em dendritos espalhados por toda a região (Figura 24). Em COR3 e COR7 houve diminuição da imunorreatividade, voltando próximo ao CONT em COR15, porém com menor imunorreatividade da arborização dendrítica (Figura 24) (Tabela 1). Os dados de immunoblotting demonstraram tendência a

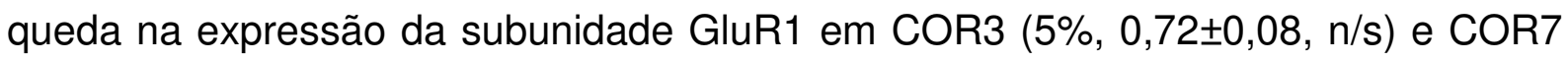
$(23 \%, 0,59 \pm 0,03 ; n / s)$, corroborando os da imuno-histoquímica, porém em COR15 houve um acréscimo de $90 \% \quad(1,45 \pm 0,17 ; \mathrm{p}<0,001)$ em relação ao CONT $(0,77 \pm 0,15)$, não verificada na imuno-histoquímica (Figura 23). 


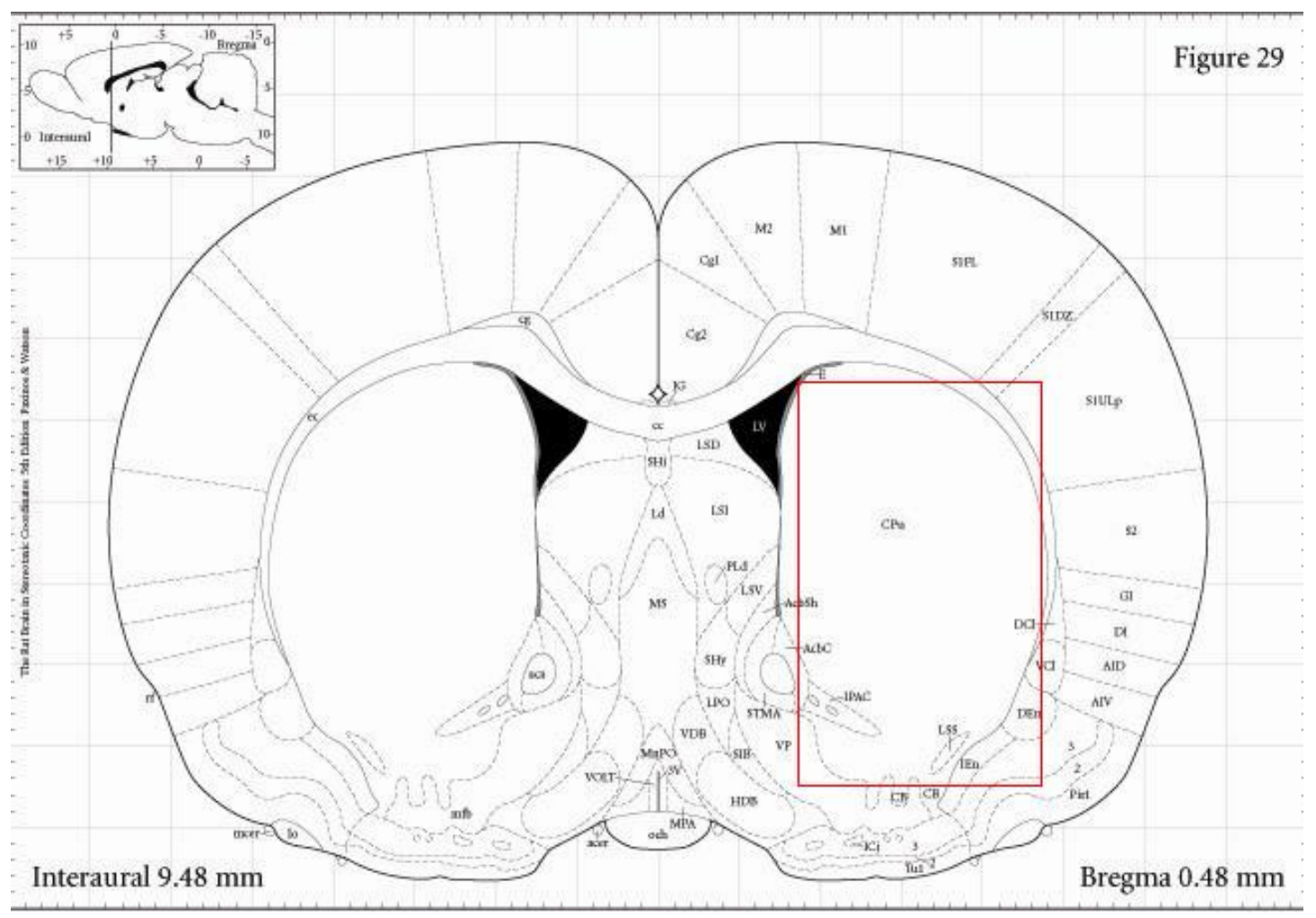

Figura 22. Esquema llustrativo do encéfalo de ratos destacando a região do estriado (caudado e putâmen). Imagem obtida de: "THE RAT BRAIN - IN STEREOTAXIC COORDINATES George Paxinos e Charles Watson". Elsevier Academic Press, 2005.

Estriado

C

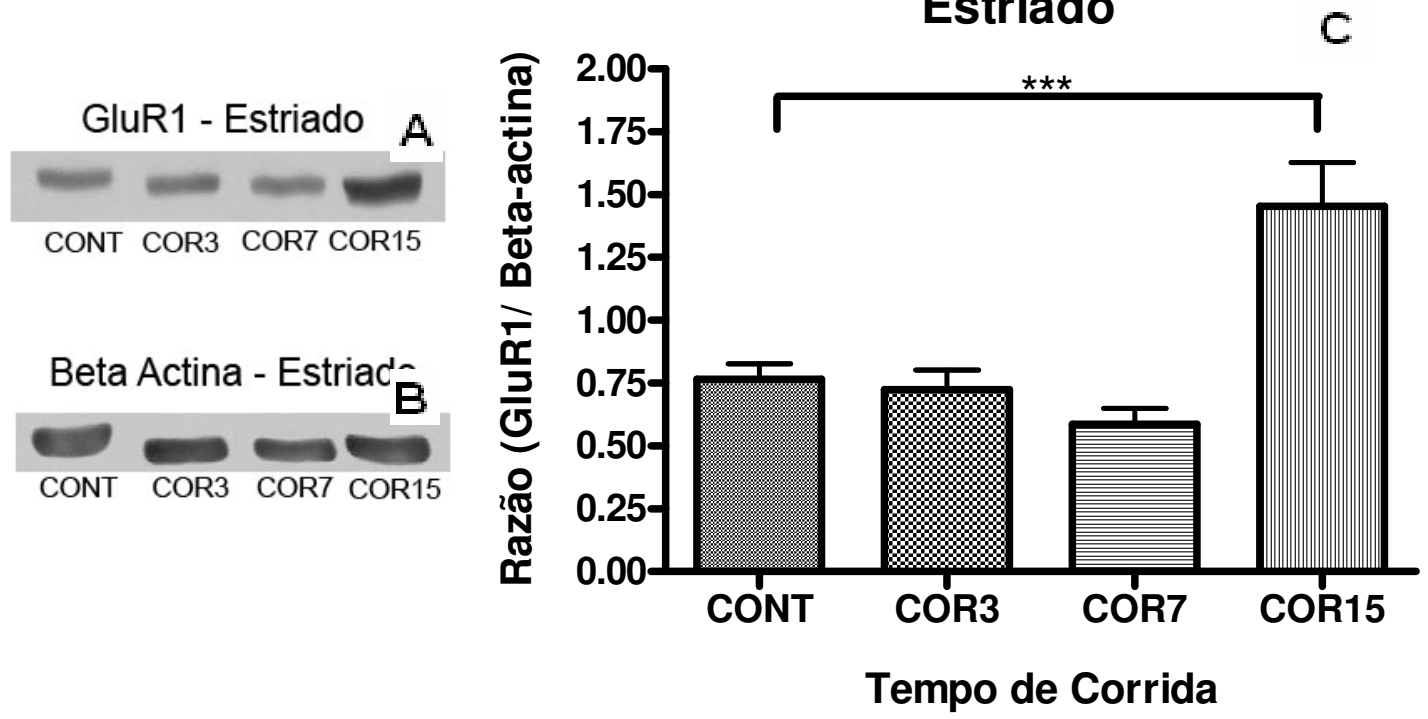

Figura 23. Efeitos do exercício na expressão da subunidade GluR1 do receptor de glutamato do tipo AMPA no estriado de ratos, avaliada por immunoblotting. A - Immunoblots de GluR1 do estriado dos animais controle (CONT), e que correram por 3 dias (COR 3), 7 dias (COR7) e 15 dias (COR15). B - controle com $\beta$-actina das amostras de A. C - Razão da densidade óptica da expressão de GluR1 e $\beta$-actina, demonstrando as diferenças nos grupos estudados. A razão da densidade óptica GluR1/ $\beta$-actina foi estatisticamente significante após 15 dias de corrida $\left({ }^{* * *} \mathrm{p}<0,001\right)$. 

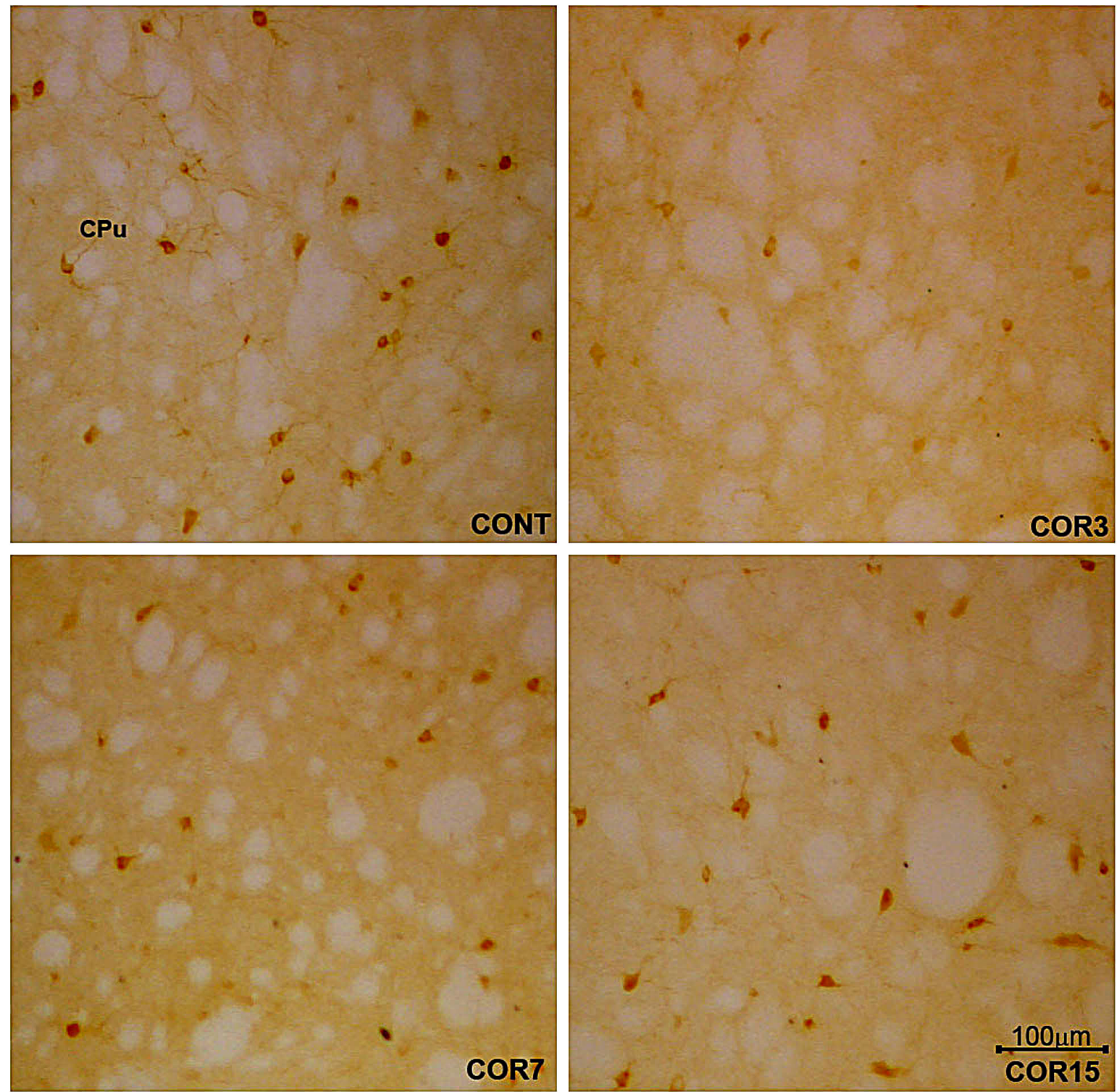

Figura 24. Imagens digitais de corte frontal do encéfalo de rato ilustrando a expressão da subunidade GluR1 no estriado (caudado e putâmen - CPu) do animal controle (CONT) e animais experimentais que correram na esteira por 3, 7 e 15 dias (COR3, COR7 e COR15, respectivamente). Note que há diminuição da marcação celular e de dendritos em COR3 e COR7, enquanto em COR15 a diminuição é na marcação dendrítica. Escala =100 $\mu \mathrm{m}$. 


\subsection{GluR2/3}

Os dados de imuno-histoquímica no $\mathrm{Cb}$ demonstraram expressão de GluR2/3 em células de Purkinje e neurópila da camada molecular. Ao comparar os grupos podemos notar que em COR3 houve diminuição da expressão em corpos celulares, porém em COR7 e COR15 há uma intensificação de marcação em ambas as estruturas GluR2/3-positivas (Figura 25) (Tabela 1).

Os dados de immunoblotting revelaram uma queda de $55 \%$ no grupo que correu 3 dias $(0,39 \pm 0,10 ; p<0,001)$, retornando à expressão de $\operatorname{CONT}(0,88 \pm 0,12)$

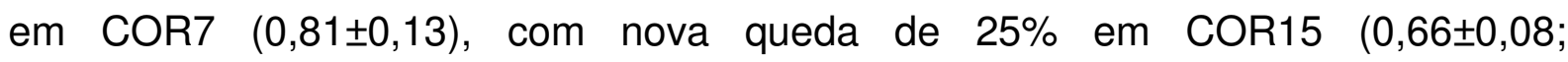
$\mathrm{p}<0,05)$ (Figura 26).

Assim a análise dos dados de imuno-histoquímica e immunoblotting nos permitem perceber que as subunidades GluR1 e GluR2/3 respondem diferentemente em cada estrutura e tempo de corrida estudados, como pode ser revisto na Tabela 1 com os dados obtidos da imuno-histoquímica, os quais são quase sempre semelhantes aos do immunoblotting. 

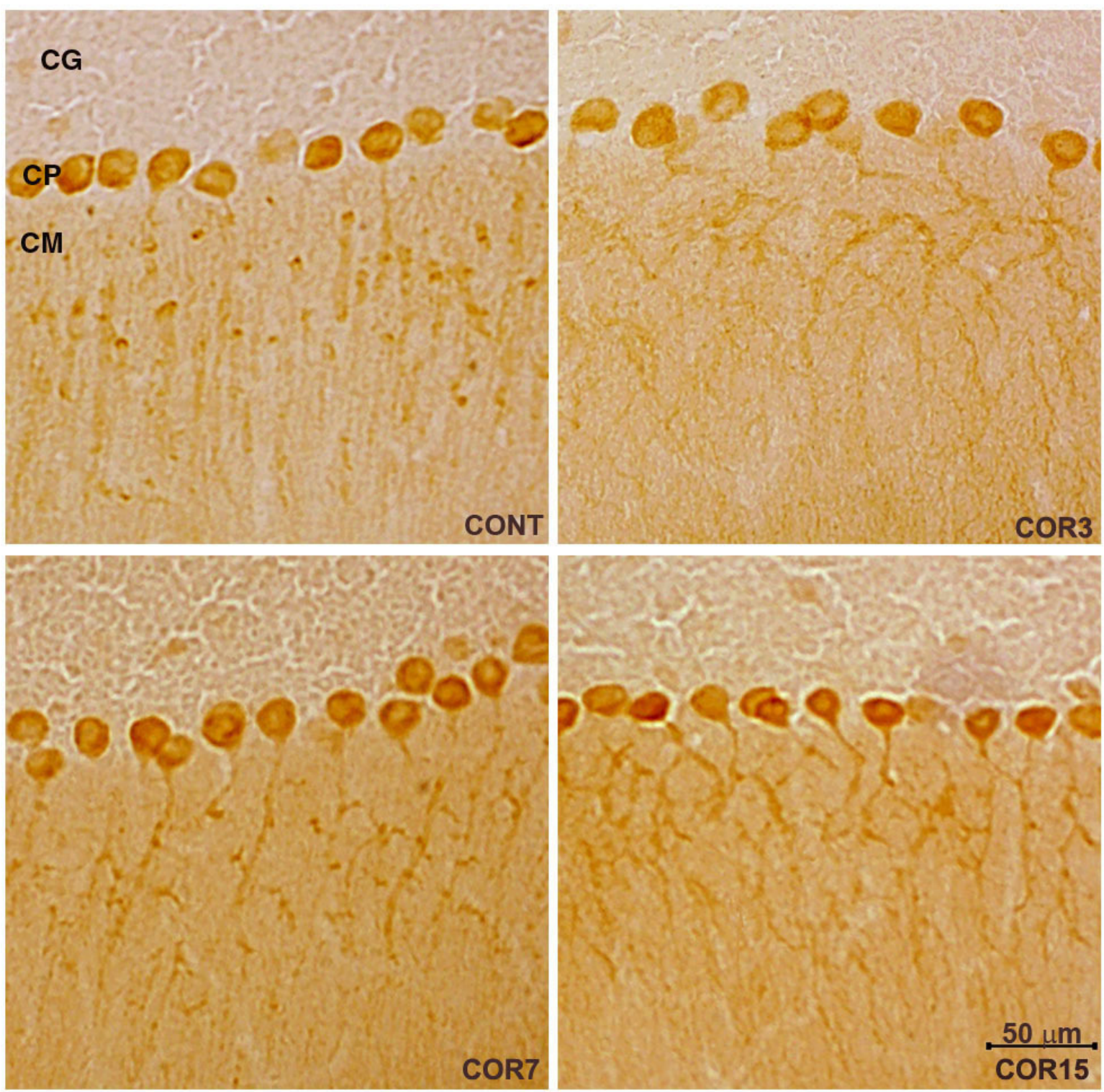

Figura 25. Imagens digitais de corte frontal do encéfalo de rato ilustrando a expressão das subunidades GluR2/3 no córtex cerebelar (camada granular - CG; camada de células de purkinje - CP; e camada molecular - CM) no animal controle (CONT) e animais experimentais que correram na esteira 3, 7 e 15 dias (COR3, COR7 e COR15, respectivamente). Note que há um aumento da imunorreatividade da arborização dendrítica da CM nos animais treinados. Escala $=50 \mu \mathrm{m}$. 
A

GluR2/3 - Cerebelo

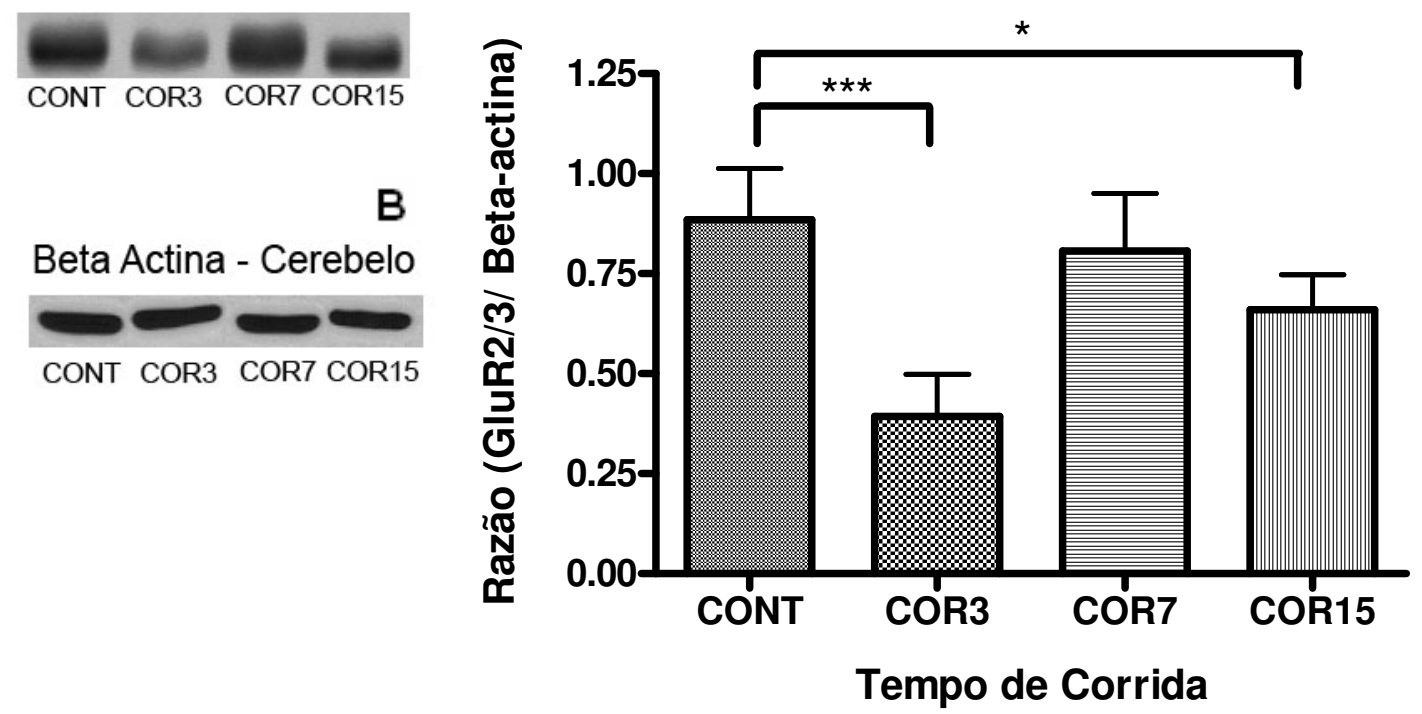

Figura 26. Efeitos do exercício na expressão das subunidades GluR2/3 do receptor de glutamato do tipo AMPA no cerebelo de ratos, avaliada por immunoblotting. A - Immunoblots de GluR2/3 do cerebelo dos animais controle (CONT), e que correram por 3 dias (COR 3), 7 dias (COR7) e 15 dias (COR15). B - controle com $\beta$-actina das amostras de A. C Razão da densidade óptica da expressão de GluR2/3 e $\beta$-actina, demonstrando as diferenças nos grupos estudados. A razão da densidade óptica GluR2/3/ $\beta$-actina foi estatisticamente significante após $3\left({ }^{* \star *} \mathrm{p}<0,001\right)$ e $15\left({ }^{*} \mathrm{p}<0,05\right)$ dias de corrida.

No GD observamos marcação em todas as camadas, porém com respostas distintas. Na camada molecular há marcação intensa de neurópila em todos os grupos estudados. Por outro lado, a expressão em células granulares e da camada polimórfica sofreu variação nos três tempos de corrida. Em COR3, houve diminuição da expressão em células granulares, que tiveram intensificada sua imunorreatividade em COR7, retornando à expressão do CONT em COR15. Células e dendritos da camada polimórfica intensificaram a marcação em COR7 mantendose até COR15 (Figura 27) (Tabela 1). Os dados do immunoblotting corroboram os dados da imuno-histoquímica de forma geral, pois demonstraram tendência ao

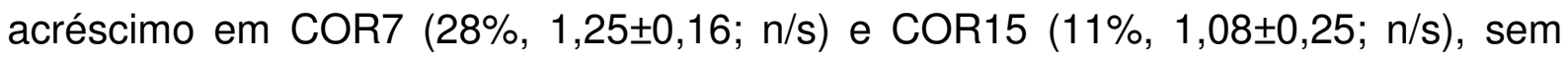
alterações em COR3 $(0,94 \pm 0,14)$ em relação ao CONT $(0,97 \pm 0,28)$ (Figura 28). 

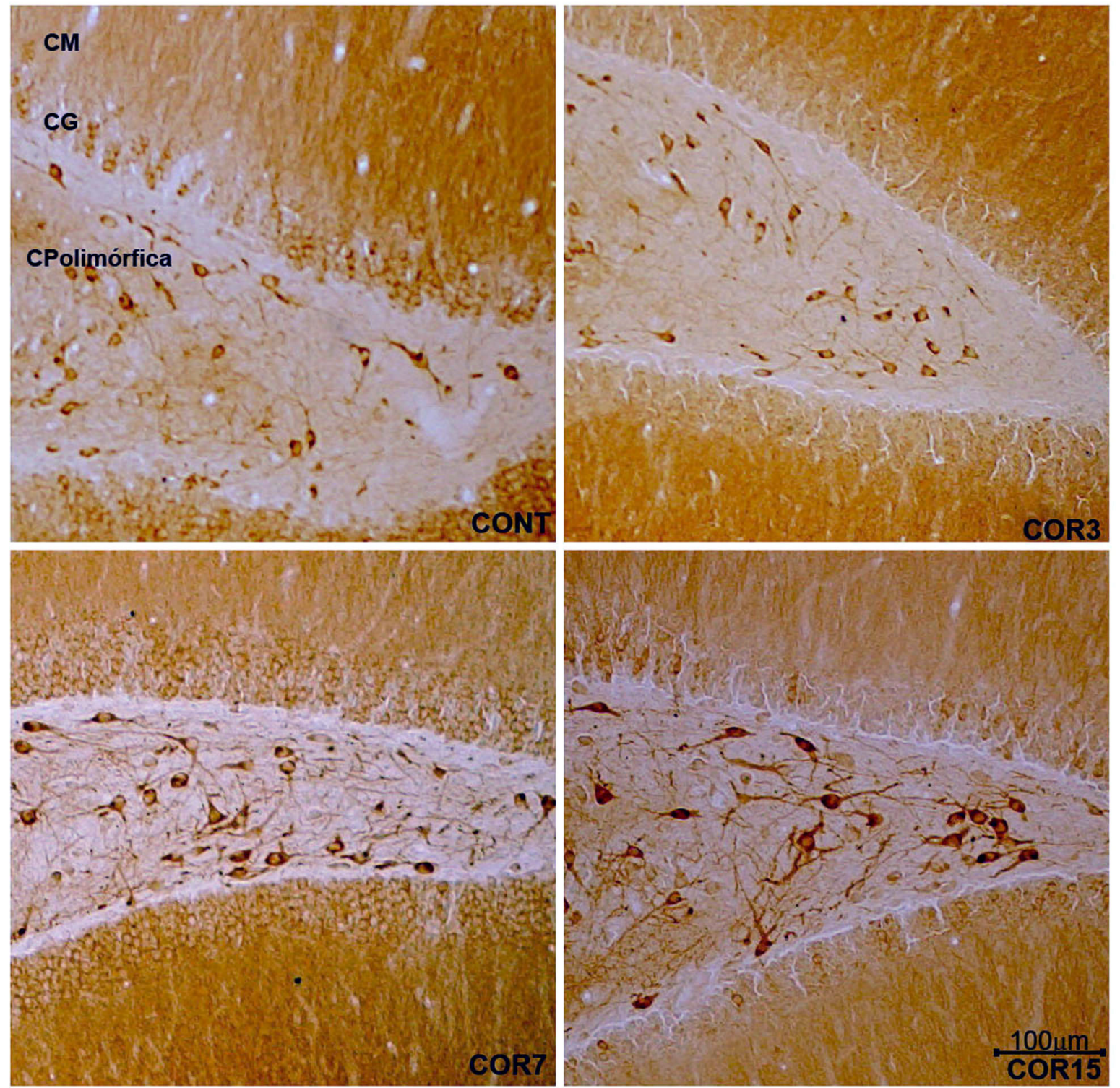

Figura 27. Imagens digitais de corte frontal do encéfalo de rato ilustrando a expressão das subunidades GluR2/3 no giro denteado (camada molecular - CM; camada granular CG; e camada de células polimórficas - CP) no animal controle (CONT) e animais experimentais que correram na esteira 3,7 e 15 dias (COR3, COR7 e COR15, respectivamente). Note que há um aumento no número e na intensidade de marcação de prolongamentos e células da camada Polimórfica, em COR7 e COR15. Escala = $100 \mu \mathrm{m}$. 


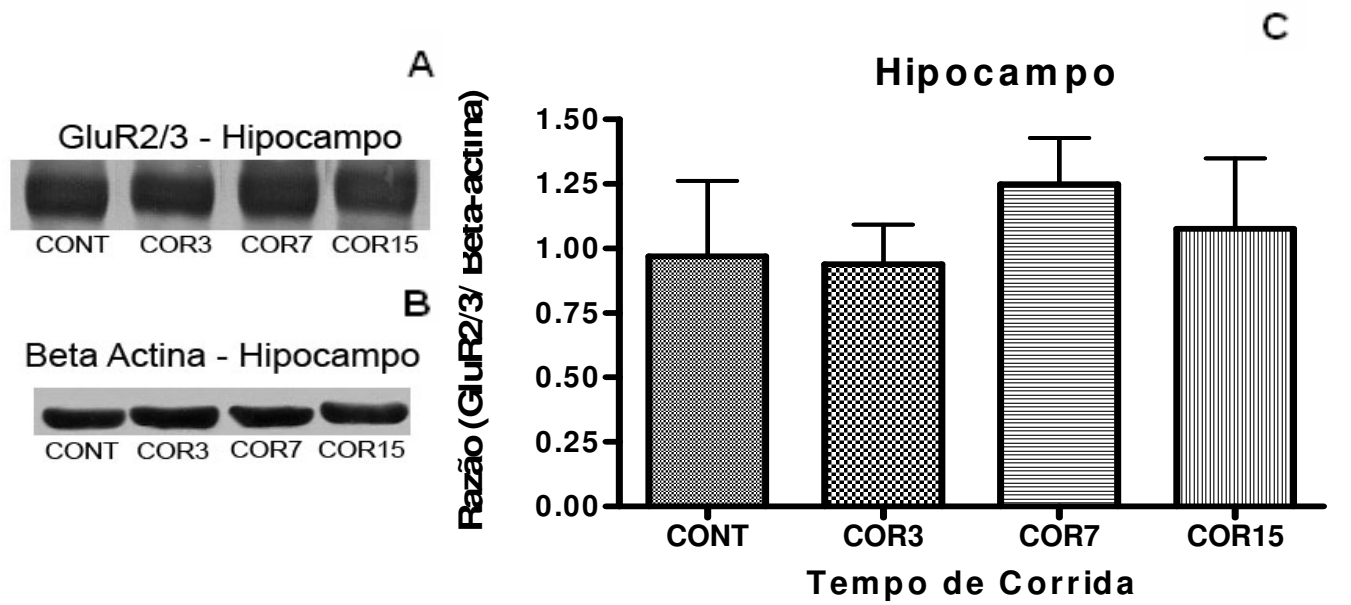

Figura 28. Efeitos do exercício na expressão das subunidades GluR2/3 do receptor de glutamato do tipo AMPA no hipocampo de ratos, avaliada por immunoblotting. A - Immunoblots de GluR2/3 do estriado dos animais controle (CONT), e que correram por 3 dias (COR 3), 7 dias (COR7) e 15 dias (COR15). B - controle com $\beta$-actina das amostras de A. C Razão da densidade óptica da expressão de GluR2/3 e $\beta$-actina, demonstrando as diferenças nos grupos estudados. A razão da densidade óptica GluR2/3/3-actina não foi estatisticamente significante.

Células de todas as camadas do córtex cerebral apresentaram-se GluR2/3-positivas, porém apresentamos aqui os dados da camada V de M1 e M2, por serem áreas envolvidas diretamente com a execução motora. Nos animais controle, em M1 podemos notar marcação de células piramidais e dendritos da camada V. Em COR3 notamos uma diminuição da expressão destas subunidades em dendritos; em COR7 há intensificação na expressão do corpo celular e dendritos, porém há um decréscimo na intensidade de marcação em COR15 (Figura 29). No entanto, em M2 as variações foram diferentes, havendo diminuição da expressão tanto em corpo celular quanto em dendritos em COR3 e COR7, intensificando-se em COR15 (Figura 30) (Tabela 1).

Os dados de immunoblotting mostraram não haver mudanças estatísticas na expressão da proteína após o treinamento, apenas uma queda aparente de $6 \% \mathrm{em}$ COR15 $(0,94 \pm 0,15 ; n / s)$, em relação ao CONT $(1,00 \pm 0,09)$ (Figura 31). 

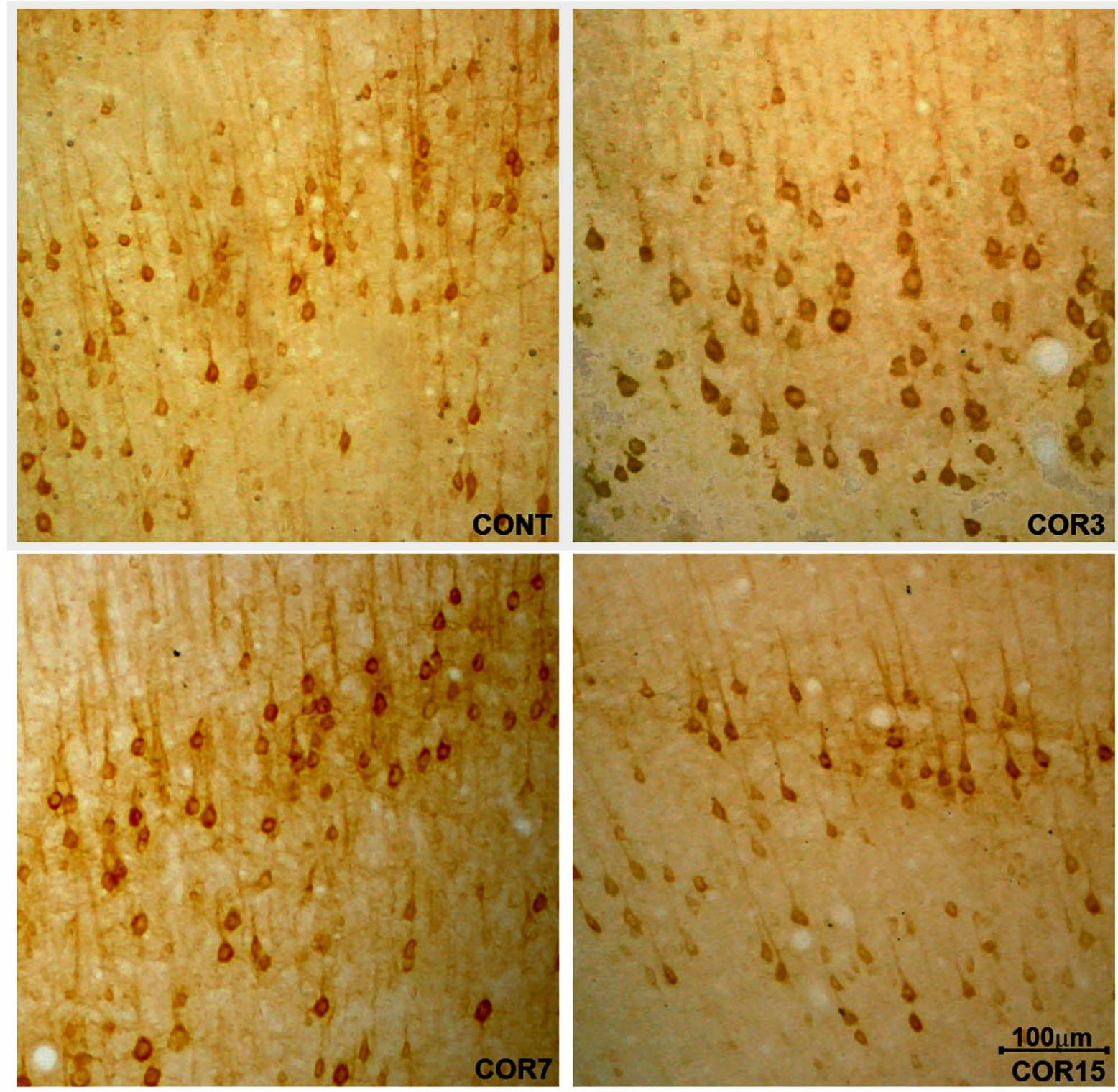

Figura 29. Imagens digitais de corte frontal do encéfalo de rato ilustrando a expressão das subunidades GluR2/3 na camada $V$ do córtex motor primário no animal controle (CONT) e animais experimentais que correram na esteira por 3, 7 e 15 dias (COR3, COR7 e COR15, respectivamente). Note que há uma diminuição de dendritos em COR3 e aumento da expressão em COR7, voltando ao padrão de marcação do CONT em COR15. Escala $=100 \mu \mathrm{m}$. 

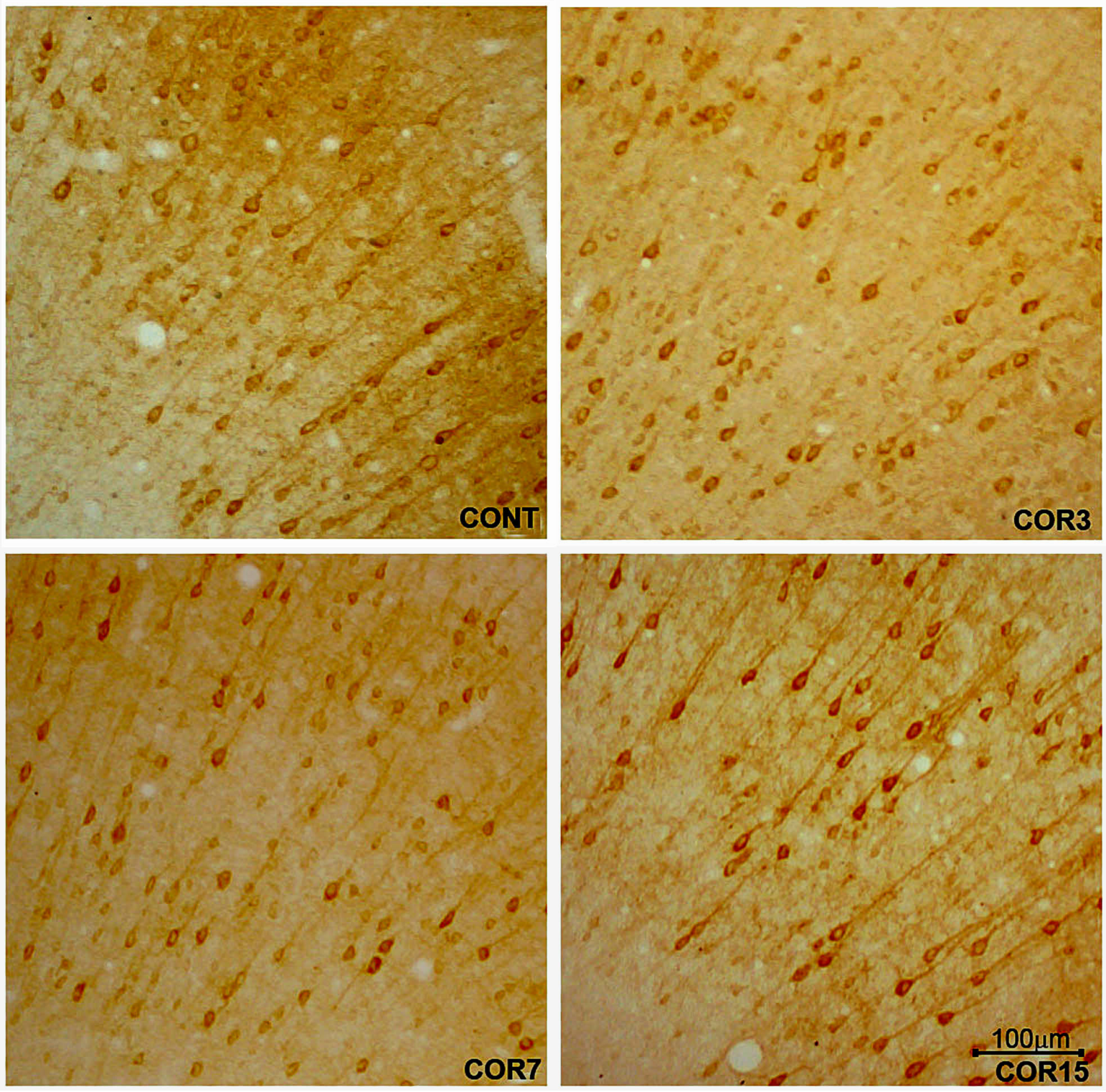

Figura 30. Imagens digitais de corte frontal do encéfalo de rato ilustrando a expressão das subunidades GluR2/3 na camada $V$ do córtex motor secundário no animal controle (CONT) e animais experimentais que correram na esteira por 3, 7 e 15 dias (COR3, COR7 e COR15, respectivamente). Note que há uma diminuição da expressão nos 3 grupos experimentais, principalmente em COR3 e COR7. Escala $=100 \mu \mathrm{m}$. 
C

A

GluR2/3 - Córtex Cerebral

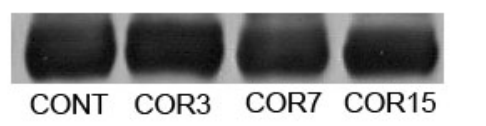

B

Beta Actina - Córtex Cerebral

CONT COR3 COR7 COR15

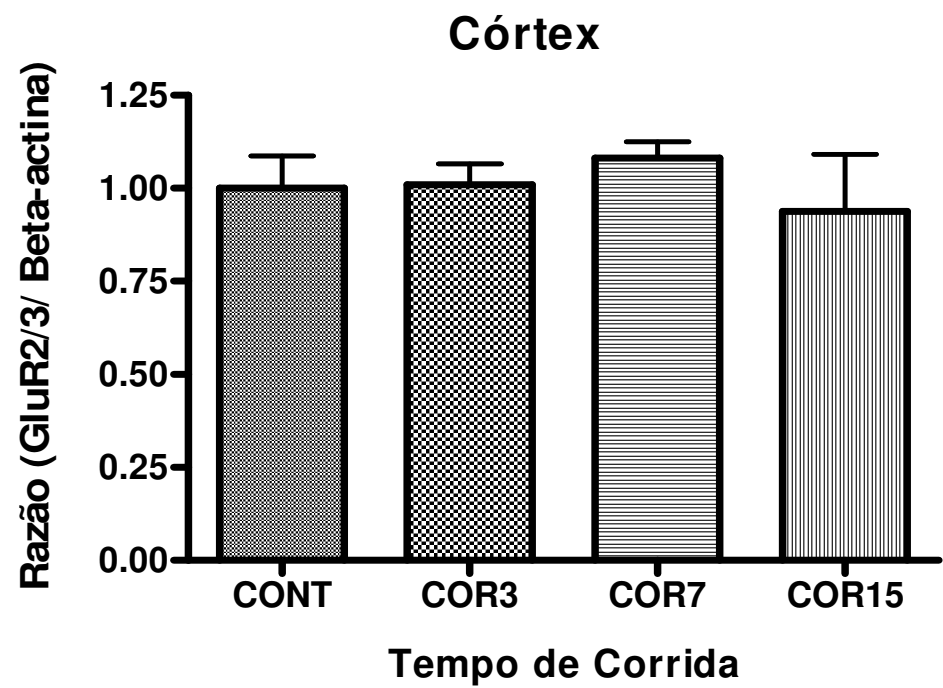

Figura 31. Efeitos do exercíco na expressão das subunidades GluR2/3 do receptor de glutamato do tipo AMPA no córtex cerebral de ratos, avaliadas por immunoblotting. A - Immunoblots de GluR2/3 do córtex cerebral dos animais controle (CONT), e que correram por 3 dias (COR 3), 7 dias (COR7) e 15 dias (COR15). B - controle com $\beta$-actina das amostras de A. C - Razão da densidade óptica da expressão de GluR2/3 e $\beta$-actina, demonstrando as diferenças nos grupos estudados. A razão da densidade óptica GluR2/3/ $\beta$-actina não foi estatisticamente significante.

$\mathrm{Na}$ região de $\mathrm{CPu}$, houve marcação citoplasmática de células arredondadas dispersas por toda estrutura. $\mathrm{Na}$ análise qualitativa parece não haver alterações da quantidade e da imunorreatividade ao longo do protocolo de exercício físico (Figura 32) (Tabela 1). Entretanto, nos dados de immunoblotting, houve aparente aumento progressivo não significativo da expressão das subunidades GluR2/3 nos diferentes tempos de corrida, sendo que houve aumento de $2 \%$ em COR3 $(1,29 \pm 0,17 ; n / s)$,

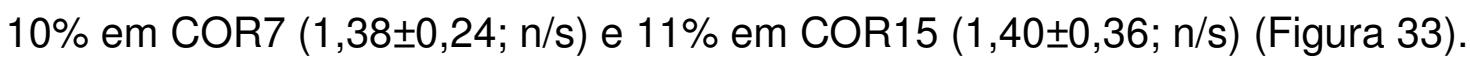



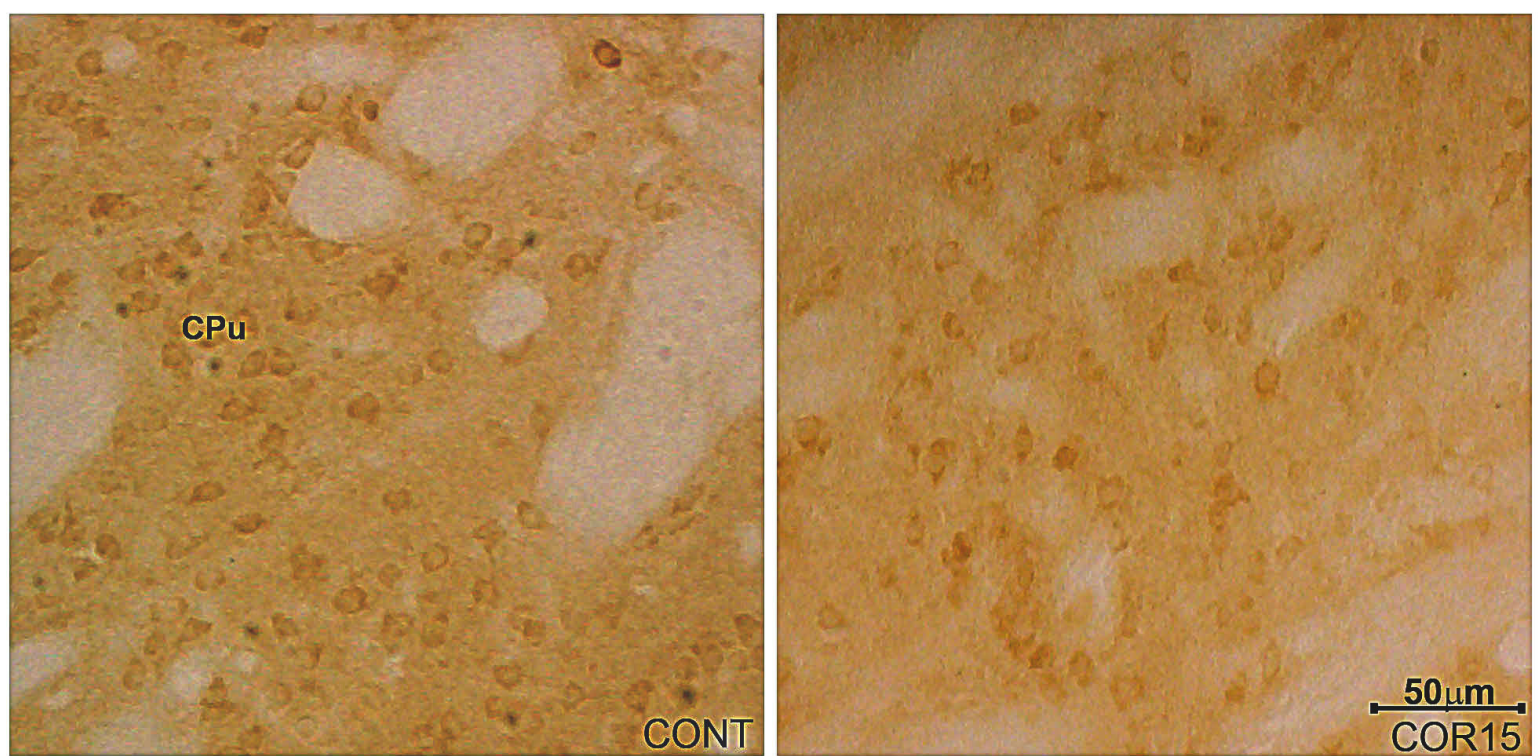

Figura 32. Imagens digitais de corte frontal do encéfalo de rato ilustrando a expressão das subunidades GluR2/3 no estriado (Caudado e putâmen - $\mathrm{CPu}$ ) do animal controle (CONT) e do animal que correu na esteira por 15 dias (COR15). Note que não há diferença de marcação entre o CONT e COR15. Escala $=100 \mu \mathrm{m}$. 


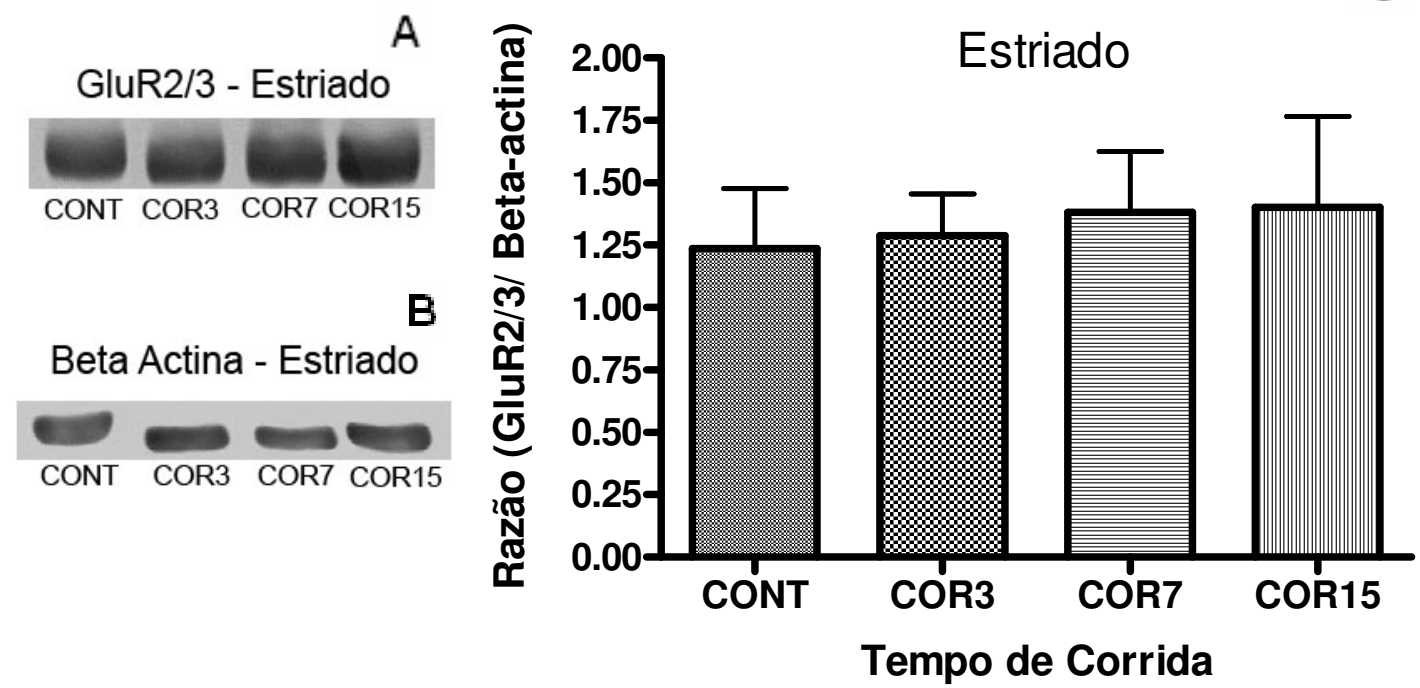

Figura 33. Efeitos do exercício na expressão das subunidades GluR2/3 do receptor de glutamato do tipo AMPA no estriado de ratos por immunoblotting. A - Immunoblots de GluR2/3 do estriado dos animais controle (CONT), corridos por 3 dias (COR 3), 7 dias (COR7) e 15 dias (COR15). B - controle com $\beta$-actina das amostras de A. C - Razão da densidade óptica da expressão de GluR2/3 e $\beta$-actina, demonstrando as diferenças nos grupos estudados. A razão da densidade óptica GluR2/3/ $\beta$-actina não foi estatisticamente significante.

\subsection{Dosagem de Corticosterona e Pesagem das Adrenais}

Os resultados de dosagem de corticosterona plasmática demonstraram aumento de $165 \%(7085 \pm 3409, p<0,01)$ no grupo COR3 e 169\% $(7184 \pm 2590$, $\mathrm{p}<0,05)$ no COR7 quando comparados ao grupo CONT $(2675 \pm 1335)$. No COR15 pareceu haver tendência de aumento na concentração (3468 \pm 2309 , n/s)(Figura 34). Por outro lado, as adrenais não apresentaram alterações em seus pesos em nenhum dos grupos estudados (Figura 35 ). 


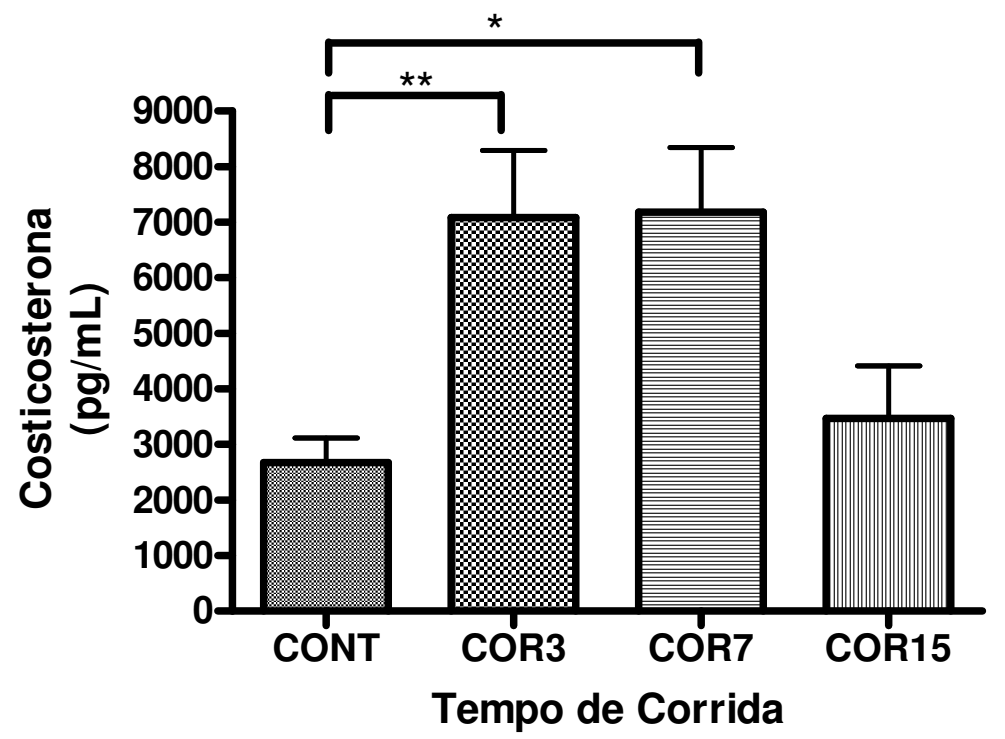

Figura 34. Efeitos do exercício na concentração de corticosterona no plasma de ratos controle e treinados, avaliadas pelo kit de elisa. No gráfico observamos um aumento significativo quando comparamos o grupo de animais controle com os corridos por $3(p<0,01)$ e 7 dias $(p<0,05)$. No entanto, aos 15 dias de corrida (COR15) nota-se que a concentração plasmática de corticosterona encontra-se semelhante ao CONT.

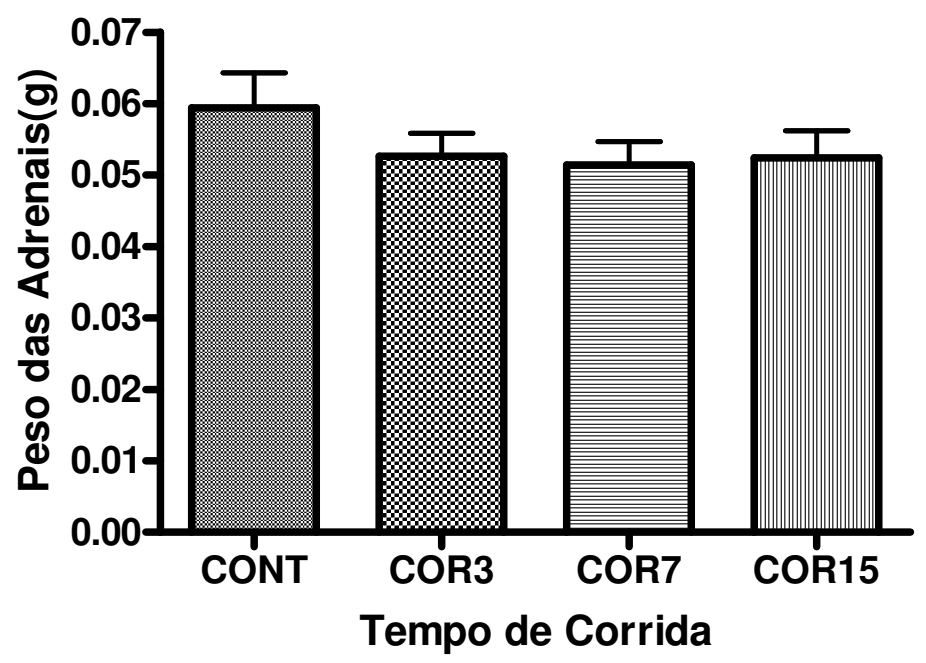

Figura 35. Efeitos do exercício no peso das adrenais de ratos controle e treinados. No gráfico observamos que não há alterações entre os pesos da adrenal entre os diferentes grupos. 


\begin{tabular}{|c|c|c|c|c|c|c|c|c|c|}
\hline & \multicolumn{4}{|c|}{ GluR1 } & \multicolumn{4}{|c|}{ GluR2/3 } \\
\hline & & CONT & COR3 & COR7 & COR15 & CONT & COR3 & COR7 & COR15 \\
\hline \multirow[t]{4}{*}{$\begin{array}{c}\text { Córtex } \\
\text { Cerebelar }\end{array}$} & $\begin{array}{c}\text { Células da } \\
\text { Camada Molecular }\end{array}$ & - & - & - & - & - & - & - & - \\
\hline & $\begin{array}{c}\text { Neurópila da } \\
\text { Camada Molecular }\end{array}$ & + & $\leftrightarrow$ & $\uparrow$ & $\uparrow$ & + & $\leftrightarrow$ & $\leftrightarrow$ & $\leftrightarrow$ \\
\hline & Células de Purkinje & + & $\downarrow$ & $\leftrightarrow$ & $\leftrightarrow / \downarrow$ & + & $\leftrightarrow$ & $\leftrightarrow$ & $\leftrightarrow$ \\
\hline & $\begin{array}{c}\text { Células da } \\
\text { Camada Granular }\end{array}$ & - & - & & - & - & - & - & - \\
\hline \multirow[t]{4}{*}{ Giro Denteado } & $\begin{array}{c}\text { Neurópila da } \\
\text { Camada Molecular }\end{array}$ & + & $\downarrow$ & $\leftrightarrow$ & $\leftrightarrow$ & + & $\leftrightarrow$ & $\leftrightarrow$ & $\leftrightarrow$ \\
\hline & $\begin{array}{c}\text { Células da } \\
\text { Camada Granular }\end{array}$ & - & - & + & - & + & $\downarrow$ & $\leftrightarrow$ & $\downarrow$ \\
\hline & $\begin{array}{c}\text { Células da } \\
\text { Camada Polimórfica }\end{array}$ & + & $\downarrow$ & $\uparrow$ & $\uparrow$ & + & $\leftrightarrow$ & $\uparrow$ & $\uparrow$ \\
\hline & $\begin{array}{c}\text { Arborização da } \\
\text { Camada Polimórfica }\end{array}$ & + & $\leftrightarrow$ & $\leftrightarrow$ & $\leftrightarrow$ & + & $\leftrightarrow$ & $\uparrow$ & $\uparrow$ \\
\hline \multirow[t]{4}{*}{ Córtex Motor } & $\begin{array}{c}\text { Células da } \\
\text { Camada V- M1 }\end{array}$ & + & $\downarrow$ & $\downarrow$ & $\leftrightarrow$ & + & $\leftrightarrow$ & $\uparrow$ & $\leftrightarrow / \downarrow$ \\
\hline & $\begin{array}{c}\text { Células da } \\
\text { Camada V- M2 }\end{array}$ & + & $\downarrow$ & $\downarrow$ & $\leftrightarrow$ & + & $\downarrow$ & $\leftrightarrow$ & $\leftrightarrow$ \\
\hline & Neurópila de M1 & + & $\downarrow$ & $\downarrow$ & $\downarrow$ & + & $\downarrow$ & $\leftrightarrow$ & $\leftrightarrow / \downarrow$ \\
\hline & Neurópila de M2 & + & $\downarrow$ & $\downarrow$ & $\downarrow$ & + & $\downarrow$ & $\leftrightarrow / \downarrow$ & $\leftrightarrow / \downarrow$ \\
\hline \multirow[t]{2}{*}{ Estriado } & Corpo Celular & + & $\downarrow$ & $\downarrow$ & $\leftrightarrow / \downarrow$ & + & $\leftrightarrow$ & $\leftrightarrow$ & $\leftrightarrow$ \\
\hline & Dendritos & + & $\downarrow$ & $\downarrow$ & $\downarrow$ & - & _- & _- & _- \\
\hline
\end{tabular}

Tabela 1. Mudanças ocorridas na imuno-histoquímica para as subunidades GluR1 e GluR2/3 dos receptores de glutamato do tipo AMPA, nas regiões estudadas após atividade física. Classificou-se a imunorreatividade em presente (+), ausente (-), diminuição em relação ao CONT ( $\downarrow$ ), aumento em relação ao CONT $(\uparrow)$, sem alterações em relação ao CONT $(\leftrightarrow)$, e pequena diminuição, porém próximo ao CONT $(\leftrightarrow / \downarrow)$. 


\section{Discussão}

As estruturas analisadas neste trabalho participam do controle motor, aprendizado e memória, incluindo o córtex motor (Kandel e Schwartz, 2000; Asanuma, 1989), estriado (Mink, 1999), cerebelo (Kakegawa et al., 2008) e hipocampo (Kampermann e Gage, 2002; Lary e Kandel, 2003). As funções desempenhadas por estas estruturas são mediadas pela maior circuitaria excitatória do SNC, ou seja, o glutamato e seus respectivos receptores. Os receptores de glutamato são capazes de promover respostas pós-sinápticas rápidas (Brockie, 2006; Watkins e Jane, 2006; Burnashev e Rozov, 2000) por formarem canais que quase sempre possibilitam a entrada de cálcio responsável por promover a despolarização celular e ativar enzimas intracelulares que atuam em respostas a curto ou longo prazo, promovendo algumas formas de plasticidade sináptica (Maren e Baudry, 1995; Asztely e Gustafsson, 1996), tais como inserção ou retirada de canais iônicos da membrana pós-sináptica (Genoux e Montgomery, 2007).

Os efeitos do exercício no sistema glutamatérgico são pesquisados desde 1955 por Vrba, porém pouco ainda é conhecido. Sabe-se que as respostas variam de acordo com o tipo, a duração e a intensidade do exercício, e que as vias que promovem respostas a curto e longo prazo da célula neuronal têm suas atividades intensificadas após atividade física. Estas vias, por sua vez, são ativadas pelo glutamato. Assim, estudos na área permitem melhor esclarecimento dos efeitos promovidos no encéfalo pelo exercício físico (Molteni et al., 2002; Dietrich et al., 2005; Leung et al., 2006).

A análise das estruturas foi realizada em ratos que correram por curtos períodos, permitindo a análise do efeito do exercício agudo. Para escolha dos dias analisados baseamo-nos nos estudos de Leung et al. (2006), que analisaram os níveis de glutamato no hipocampo, por microdiálise, em animais que realizaram corrida em esteira após isquemia focal. Os resultados deste estudo demonstraram haver um acréscimo nos níveis de glutamato no hipocampo devido ao exercício e não à lesão nos sete primeiros dias de corrida, sofrendo decréscimo após o sétimo dia, retornando aos níveis iniciais no décimo-quarto dia. Estes dados corroboram os 
de Bland et al. (1999) que demonstraram que a atividade motora promove aumento nos níveis de glutamato no córtex sensório-motor, hipocampo e estriado. Os dados de nossa pesquisa demonstraram respostas distintas das subunidades GluR1 e GluR2/3 em todas as estruturas e grupos estudados, que serão discutidas a seguir, sendo divididas por estruturas. Vale ressaltar que alguns dados, mesmo que não sejam sgnificativos estatisticamente, serão citados e discutidos, pois pequenas alterações na expressão do receptor pode ser capaz de gerar mudanças benéficas ou até mesmo maléficas ao organismo.

\subsection{Cerebelo}

O cerebelo é responsável pela correção motora. Ele participa na integração sômatossensorial (Manzoni, 2007), no fornecimento de informação do movimento ao córtex (Bonnefoi-Kyriacou et al., 1998) e na aquisição de coordenação motora e aprendizado espacial (Joyal et al., 1996). Logo, estudar as mudanças promovidas pós exercício neste circuito complexo é de extrema importância. Holschneider et al. (2007) treinaram ratos por seis semanas em esteira, promovendo assim uma reorganização do circuito capaz de promover uma resposta automática dos animais. Ao analisarem a atividade cerebral, observaram aumento da ativação dos núcleos cerebelares profundos (denteado, interpósito e fastigial) após 6 semanas. Este estudo revela uma maior ativação cerebelar em respostas automáticas, e além disso, estudos anteriores deste mesmo grupo (Holschneider et al., 2003) revelaram haver aumento do fluxo sanguíneo para a região cerebelar de ratos, principalmente para a região da linha média, responsável pela postura e locomoção, o que também foi demonstrado por Fukuyama et al. (1997) em humanos. Apesar de não haver estudos que demonstrem aumento da liberação de glutamato especificamente no cerebelo após ou durante atividade física, podemos sugerir que o aumento do fluxo sanguíneo local é associado ao aumento da atividade neural e assim ao aumento na liberação do neurotransmissor, que já foi demonstrado em outras áreas (Bland et al., 1999; Leung et al., 2006).

O circuito cerebelar promove adaptações motoras, principalmente através de sinapses cerebelo-talâmicas (saída cerebelar), essenciais nas atividades motoras. 
Estas sinapses exibem características estruturais sugestivas de serem capazes de formar novas sinapses e alterar a eficácia de transmissão das já existentes. A LTP nas sinapses cerebelo-talâmicas foi provocada mediante estímulos fortes e frequentes em estudos in vitro (Aumann, 2002). Por outro lado, em situações de estímulo repetitivo e fraco de fibras paralelas e trepadeiras (entrada cerebelar) ocorre a LTD, bem descritas nas células de Purkinje, havendo retirada de receptores do tipo AMPA da membrana celular pós-sináptica (Ito, 2002).

Em nossas análises do cerebelo, a técnica de immunoblotting revelou haver a mesma quantidade de GluR1 e GluR2/3 no animal controle. A análise qualitativa da região do córtex cerebelar pela imuno-histoquímica revela maior marcação para GluR2/3 em células de Purkinje e de GluR1 na neurópila da camada molecular. Nos grupos treinados houve uma queda na expressão das subunidades GluR2/3 em COR3, seguida de acréscimo em COR7, ficando semelhante ao CONT, com nova queda em COR15. Enquanto, GluR1 apresentou tendência à queda em COR3, tornando-se mais expressa do que GluR2/3, com tendência ao acréscimo em COR7, retornando aos níveis do CONT em COR15. Assim, há maior expressão de GluR1 do que GluR2/3 aos 15 dias de corrida.

Portanto, com os resultados apresentados sugerimos que o protocolo realizado em nosso estudo foi capaz de promover mudanças plásticas no córtex cerebelar. Neste caso as mudanças plásticas podem ocorrer para refinar as mudanças ocorridas no hábito motor do animal, pois apesar de a corrida ter o mesmo gesto motor da caminhada, uma atividade automática, no protocolo o animal é forçado a exercitar-se sendo colocado para correr com velocidade e frequência controladas, necessitando de ajustes centrais. Com a queda, em COR3, na expressão das subunidades GluR2/3, a subunidade GluR1 tornou-se mais expressa, assim esta alteração pode estar associada à reestruturação do circuito após a corrida (Holschneider et al., 2003, 2007). A diminuição de GluR2/3 pode resultar na formação de maior quantidade de canais formados por GluR1, o que pode favorecer o influxo de cálcio, sugerindo despolarização celular mais rápida e maior acionamento de proteínas e segundos mensageiros responsáveis por respostas intracelulares. Não podemos afirmar em qual região do cerebelo ocorre esta remodelação, pois os nossos resultados de immunoblotting referem-se a todo o cerebelo (córtex cerebelar e núcleos profundos). Apesar de a subunidade GluR1 ter 
apresentado queda não significativa na análise por immunoblotting, a análise qualitativa da imuno-histoquímica revelou diminuição notável na expressão de GluR1 em células de Purkinje, enquanto a expressão de GluR2/3 em células de Purkinje parece sofrer pequena diminuição, corroborando os dados de immunoblotting. Logo, podemos sugerir que o exercício físico repetitivo a curto prazo facilita a indução da LTD em células de Purkinje, promovendo diminuição de subunidades do tipo AMPA na membrana pós-sináptica, tanto de GluR1 como de GluR2/3. Porém, a diminuição é maior para GluR2/3, corroborando os estudos que demonstraram haver maior diminuição da subunidade GluR2 na indução de LTD no cerebelo (Steinberg et al., 2004; Hanley e Henley, 2006;) Assim, podemos sugerir que nas células de Purkinje ocorre diminuição da transmissão sináptica (provavelmente pela LTD).

No sétimo dia de corrida já houve reorganização do circuito motor ao novo estímulo (Holschneider et al., 2003, 2007), e a expressão de GluR1 e GluR2/3, tanto no immunoblotting quanto na imuno-histoquímica, volta ser semelhante ao CONT. Após 15 dias de treino, a atividade já foi refinada e tornou-se completamente automática, promovendo maior ativação do circuito cerebelar como mostrado por Holschneider et al. (2007), ao descreverem um aumento maior na atividade dos núcleos cerebelares profundos após exercício físico crônico se comparado ao agudo. Em COR15, nossos dados de immunoblotting mostram queda na expressão de GluR2/3, tornando maior a proporção de GluR1/GluR2/3, enquanto na imunohistoquímica a expressão de GluR2/3 em células de Purkinje e neurópila da camada molecular mostraram-se inalteradas. Assim, sugerimos que o resultado do immunoblotting reflete o aumento da atividade das vias eferentes do cerebelo, como mostrado por Holschneider et al. (2007), pois com maior proporção de GluR1 a dessensibilização do neurônio poderá ser mais rápida, o que é essencial nas respostas automáticas, enquanto a região do córtex cerebelar não parece sofrer alterações nesta fase do exercício. Dados com maior tempo de treino devem ser colhidos para confirmar se o nosso protocolo a longo prazo realmente é capaz de promover respostas distintas, ou seja, se em fases crônicas haverá mudanças diferentes da fase aguda que possam corroborar os dados de Holschneider et al. (2003 e 2007), visto que o aprendizado motor promove alterações nos circuitos cerebelares causando diminuição da atividade das células de Purkinje (Kleim et al., 1998). 


\subsection{Hipocampo}

Sabe-se que tanto no exercício agudo quanto no exercício crônico a atividade hipocampal encontra-se aumentada (Holschneider et al., 2003, 2007), porém a liberação do neurotransmissor é diferente. Em fases mais agudas a liberação de glutamato está aumentada (Bland et al., 1999; Leung et al., 2006) enquanto após o sétimo dia sofre queda na concentração, retornando às taxas do CONT após 14 dias de corrida (Leung et al., 2006). Em consequência da liberação distinta de glutamato, a ativação de genes relacionados com a plasticidade também é diferente na fase aguda e crônica do exercício voluntário como estudado por Molteni et al. (2002). Eles utilizaram três tempos de corrida distintos. Entre 3 e 7 dias de exercício, observou-se um acréscimo na expressão gênica de GluR1 e NR1 e uma diminuição com 28 dias; já o gene do transportador de glutamato EAAC1 está aumentado apenas com 3 dias, o que possivelmente representa um mecanismo protetor ativado pelo exercício pelo aumento na liberação de glutamato em fases agudas. Na fase aguda, o hipocampo tem o papel de memorizar o que está ocorrendo no sentido de novidade, enquanto na fase crônica as informações já foram enviadas às áreas corticais.

Além das alterações nos níveis de neurotransmissor, há mudanças nos mecanismos envolvidos na proliferação celular no adulto na região do GD, responsável por promover a neurogênese (van Praag et al., 1999). Os principais responsáveis pela neurogênese são os fatores neurotróficos, tais como o fator neurotrófico derivado do encéfalo (BDNF), que é também responsável por alterar a morfologia da célula e dendritos já existentes, podendo gerar mudanças no comportamento (Tyler e Pozzo-Miller, 2003; Griesbach et al., 2004; Eadie et al., 2005; Lou et al., 2008), e induzir LTP (van Praag et al., 1999; Kramar et al., 2004).

Nossos resultados de immunoblotting referem-se a todas as regiões do hipocampo, enquanto a análise de imuno-histoquímica foi feita apenas na região do GD. Os dados colhidos no immunoblotting revelaram uma diminuição da subunidade GluR1 em COR3, voltando aos níveis do CONT em COR7 e COR15. GluR2/3 não sofreu alterações, apenas tendência ao acréscimo no grupo COR7. Já a análise da imuno-histoquímica revelou diminuição da expressão de GluR1 em todas as camadas no grupo COR3; em COR7 e COR15 há aumento na marcação da 
arborização da camada polimórfica. Apenas no grupo COR7 foi observada marcação de células, que parecem ser interneurônios na camada granular. GluR2/3 apresentou intensificação da expressão em células da camada polimórfica, provavelmente células musgosas, e dendritos nos grupos COR7 e COR15. As células da camada granular apresentaram diminuição da expressão nos grupos COR3 e COR15.

De acordo com os resultados expostos neste trabalho podemos sugerir que 0 protocolo utilizado foi capaz de promover alterações na estruturação de alguns dos componentes da transmissão sináptica após o exercício, como já foi descrito por alguns autores (Dietrich et al., 2005; Eadie et al., 2005; Yaka et al., 2007); porém, as alterações ocorridas no hipocampo nos primeiros dias em nosso estudo poderiam também resultar do estresse ao qual os animais foram submetidos durante 0 exercício físico forçado (Hirata et al., 2008). Por este motivo, foi realizada a dosagem de corticosterona plasmática de todos os grupos de animais. A dosagem deste hormônio é capaz de quantificar o estresse do animal visto que sua produção é controlada pelo eixo-hipotálamo-hipófise-adrenal (Soya, 2001) que é mais ativado em situações que exijam do corpo uma resposta adaptativa ao estímulo (Eliot, 1992).

Vale lembrar que a maioria dos estudos envolvendo LTP, neurogênese e exercício físico são protocolos de exercício crônico voluntário, enquanto nossos dados são de exercício forçado agudo. Chen et al. (2007) demonstraram que o exercício voluntário e o forçado ativam cascatas de sinalização protéicas diferentes. A fim de minimizar o estresse, o protocolo de exercício realizado neste estudo foi adaptado para que os animais pudessem ser submetidos ao treinamento durante seu período ativo (Holmes et al., 2004).

Os resultados da dosagem de corticosterona revelaram um acréscimo na concentração plasmática deste hormônio com 3 e 7 dias de corrida, com retorno aos níveis basais em COR15. Desta maneira, não é possível afirmar que os resultados obtidos na avaliação da expressão de receptores de glutamato durante este período estejam diretamente relacionados aos efeitos da atividade física. Os resultados revelaram também que, apesar do aumento nos níveis de corticosterona, as adrenais não sofreram mudança em seu peso, corroborando os resultados obtidos por Brown et al. (2007). De acordo com a literatura, o acréscimo de corticosterona 
plasmática após períodos curtos de exercício físico é freqüentemente relatado, sendo esta uma situação de estresse fisiológico (Huang et al., 2006); porém, os níveis hormonais parecem retornar a níveis basais em períodos mais crônicos da atividade, e assim nossos dados corroboram os encontrados por diversos autores (Tharp e Buuck, 1971; Frenki e Csalay apud Tharp e Buuck, 1974; Kawashima et al., 2004; Brown et al., 2007). Acredita-se que com o tempo a glândula adrenal adaptese ao estresse diminuindo assim a liberação de hormônios (Tharp e Buuck, 1974). Além disso, o exercício forçado é capaz de promover maior aumento nos níveis de corticosterona do que o voluntário, sendo a modalidade natação mais estressante do que a corrida em esteira (Contarteze et al., 2008). Em nosso estudo, os dados obtidos com 3 dias de corrida revelaram diminuição na expressão de GluR1 por immunoblotting e imuno-histoquímica. Tal redução foi observada em células e dendritos nas três camadas celulares do GD, de maneira semelhante aos dados de estresse obtidos em ratos adultos e jovens (Shors e Thompson et al., 1992; Hu et al., 2007; Yaka et al., 2007; Hirata et al., 2008). A dosagem de corticosterona realizada em nosso estudo também corrobora estes resultados. No entanto, outros estudos em períodos crônicos demonstram haver aumento na liberação de glutamato (Bland et al., 1999; Leung et al., 2006), o que promoveria aumento na expressão de receptores de glutamato, principalmente GluR1 (Hu et al., 2007). O hipocampo é muito vulnerável ao estresse devido ao aumento nos níveis de glicocorticóides (Kim e Diamond, 2002). Com o aumento nos níveis de glicocorticóides há diminuição na expressão de GluR1, e assim queda da LTP.

No sétimo dia de corrida os níveis plasmáticos de corticosterona continuam semelhantes ao terceiro dia, porém a expressão de GluR1 apresenta tendência ao aumento, sugerindo que o efeito da corticosterona foi minimizado por reajustes fisiológicos. Estes dados também sugeririam a reversão do quadro de estresse apresentado em COR3, e até mesmo indução de LTP, já que o aumento de receptores do tipo AMPA é o principal responsável por este fenômeno (Shors e Thompson, 1992). Hirata et al. (2008) demonstraram que a supressão da LTP é dependente do agente estressante e pode ser revertida. Persson et al. (2004) demonstraram que após 9 dias de corrida os parâmetros de estresse causados pela corrida voluntária têm nível semelhante ao controle. Além disso, estudos do efeito do exercício crônico tanto voluntário (Holmes et al., 2004; van Praag et al., 1999) 
quanto forçado (Carro et al., 2001) demonstram haver benefícios para o hipocampo, como neurogênese aumentada, sugerindo reversão do quadro de estresse com o tempo.

Podemos observar também na imuno-histoquímica aumento da expressão de GluR1 em células e dendritos da camada polimórfica, responsável pela excitação do hipocampo, e de células granulares. Apesar da LTP em CA1 ser estimulada pelas células da camada granular que se encontram aparentemente mais marcadas, o aumento na expressão de receptores nas células da camada polimórfica sugere que as células granulares estão sendo mais estimuladas, favorecendo a indução da LTP. Com 15 dias de corrida, fase em que a concentração plasmática de corticosterona encontra-se semelhante aos níveis controles, o immunoblotting revelou expressão semelhante ao controle, porém a imuno-histoquímica manteve a marcação semelhante ao COR7, ou seja, intensa. Assim, podemos sugerir que o retorno da expressão das subunidades semelhante ao CONT deve-se à diminuição da expressão em outras regiões do hipocampo e não no GD. Assim, seria importante a análise detalhada da imuno-histoquímica de cada região para avaliarmos este aspecto.

\subsection{Córtex Motor}

Estudos com córtices motores revelam que em fases crônicas de exercício há diminuição da atividade celular e da perfusão local (Holschneider et al., 2007). Em fases agudas a atividade celular está aumentada (Holschneider et al., 2003), corroborando os dados de Vissing et al. (1996) e Isaacs et al. (1992) que demonstraram que a atividade neuronal está aumentada durante e após atividade física. Li et al. (2005) demonstraram que, para ofertar oxigênio e glicose suficiente ao neurônio, que está com a atividade aumentada, há proliferação de astrócitos concomitante com a proliferação endotelial, o que promove angiogênese na região. Além disso, associado à angiogênese e ao aumento da atividade celular, Bland et al. (1999) demonstraram por microdiálise que há um aumento na concentração de glutamato durante e após o movimento na região do córtex sensório-motor. 
Os dados obtidos no immunoblotting dos córtices motor e sensorial demonstraram queda na expressão de GluR1 em COR3 e COR7, retornando ao padrão do CONT em COR15, corroborando as respostas após exercício obtido na região $M 1$, porém $M 2$ continua com a expressão diminuída em COR15. A análise de immunoblotting para GluR2/3 demonstrou que a expressão não altera, porém na imuno-histoquímica na região do M2 notamos diminuição da expressão em todos os grupos treinados, com quedas mais acentuadas em arborizações dendríticas em COR3 e COR7. Em M1 há uma diminuição na marcação da arborização dendrítica, seguida de acréscimo em COR7 principalmente em arborização dendrítica, com nova diminuição da expressão em COR15, ficando semelhante ao CONT. Porém em todos os grupos as subunidades GluR2/3 apresentaram-se mais expressa do que a GluR1.

Assim, podemos sugerir que o protocolo de atividade física realizado em nossos estudos foi capaz de promover aumento da atividade celular e da liberação de glutamato no córtex motor e sensorial. Porém, vale lembrar que as respostas a curto e longo prazo são diferentes. Assim, a curto prazo (COR3 e 7) a célula nervosa pode ter apresentado como resposta protetora a diminuição da expressão de GluR1 e consequentemente menos canais permeáveis ao cálcio, evitando excitotoxicidade pelo aumento de neurotransmissor na fenda sináptica. Porém, no décimo quinto dia de corrida podem ter sido iniciadas respostas de longo prazo. Estudos de Dietrich et al. (2005) com exercício crônico em camundongos demonstraram aumento na expressão de receptores do tipo AMPA, com acréscimo na expressão de GluR1 e GluR2/3 no córtex cerebral pela análise por immunoblotting, além de aumentar a expressão de proteínas responsáveis pelo ancoramento das subunidades GluR1 (SAP-97) e GluR2/3 (GRIP-1). Possivelmente um protocolo mais prolongado da modalidade de exercício proposto em nosso estudo poderá promover respostas que corroborem os dados de Dietrich e colaboradores (2005).

Por outro lado, os dados da imuno-histoquímica diferem dos de immunoblotting porque a análise, apesar de qualitativa, foi específica da camada de saída dos córtices motores. Assim, podemos sugerir que nos grupos COR3 e COR7 houve diminuição da expressão de ambas as subunidades como efeito protetor ao aumento da atividade celular local e da liberação de glutamato, porém com 15 dias já houve remodelamento dos circuitos responsáveis pela execução motora, tais 
como cerebelo e estriado (Holschneider et al., 2007), além de a atividade celular ter retornado aos níveis basais ou estarem diminuídas. Com as alterações promovidas a longo prazo, a expressão das subunidades do tipo AMPA volta a ser semelhante ao CONT na camada $\mathrm{V}$ de $\mathrm{M} 1$ responsável pela execução do movimento (Laursen e Wiesendanger, 1967; Laursen, 1970; Asanuma et al. 1981; Asanuma, 1989; Kandel e Schwartz, 2000). Porém, a expressão em M2 de ambas as subunidades continua diminuída, provavelmente por esta região não ser mais tão ativa em respostas automáticas como é em respostas mais complexas que necessitam de planejamento, correção e integração de diferentes áreas sensoriais (Asanuma, 1989; Kandel e Schwartz, 2000). Nossos dados mostraram regulação plástica distinta entre M1 e M2, que pode ser explicada por elas terem papéis importantes em fases diferentes do exercício; porém, ambos córtices apresentaram regulação negativa na expressão de receptores do tipo AMPA nos primeiros 7 dias de atividade, ou seja, na fase mais aguda.

\subsection{Estriado}

No estriado, estudos de eletrofisiologia confirmaram que as entradas excitatórias corticais são mediadas por receptores do tipo AMPA (Calabresi et al., 1998; Kita, 1996), sendo o estriado então, responsável por receber as aferências corticais e enviar as informações às outras estruturas que constituem os núcleos da base (Gerfen, 1988). Nossos resultados foram semelhantes na imuno-histoquímica e no immunoblotting, exceto em COR15. Nos grupos COR3 e COR7, houve tendência à queda da expressão da subunidade GluR1, porém em COR15 houve um acréscimo de 90\%, notável apenas no immunoblotting. Por outro lado, as subunidades GluR2/3, apresentaram apenas uma tendência ao acréscimo progressivo nos diferentes grupos estudados. Assim, a subunidade que apresentou resposta significante ao exercício físico nos núcleos caudado e putâmen foi apenas GluR1, após 15 dias de corrida.

Deng et al. (2007) demonstraram que a imunorreatividade para GluR2 é mais abundante do que para GluR1 em neurônios de projeção do estriado, sendo que 50$70 \%$ dos neurônios de projeção contêm GluR1 (Vorobjev et al., 2000). Os neurônios 
apresentam marcação citoplasmática em células grandes ou médias com intensidade moderada de ambas as subunidades, e apenas GluR1 em pericários e dendritos proximais. Assim, nossos dados corroboram os deste estudo, pois em todos os grupos estudados a expressão para GluR2/3 apresentou-se mais abundante do que para GluR1, exceto na análise de immunoblotting em COR15, quando a densidade óptica para expressão de GluR1 ficou semelhante à de GluR2/3. Além disso, houve marcação para GluR1 apenas em dendritos e pericários (Deng et al., 2007).

Alguns estudos já analisaram o efeito do exercício no estriado. Bland et al. (1999) demonstraram haver aumento dos níveis de glutamato após movimento espontâneo dos membros na região do estriado, possivelmente pelo aumento em sua atividade e assim, aumento do fluxo sanguíneo para a região (Holschneider et al., 2003); este estudo mostrou haver angiogênese com 3 semanas de atividade física em esteira, que continua ocorrendo após 3 semanas mesmo sem atividade física; associado à angiogênese, ocorre proliferação de astrócitos que participa diretamente e ativamente na regulação da formação capilar, favorecendo assim uma melhora do aporte energético para a região em que se encontram neurônios mais ativos (Li et al., 2005). Liste et al. (1997) provaram que a corrida de ratos em esteira é capaz de ativar o estriado, ao demonstrarem aumento na expressão de Fos (proteína nuclear capaz de promover mudanças na função neuronal e de segundos mensageiros), após exercício, por meio da interação de glutamato e dopamina no estriado. O aumento dos níveis de glutamato (Bland et al., 1999) e dopamina (Hattori et al., 1994) durante e após o exercício físico promove potencialização da interação destes neurotransmissores e consequentemente da expressão de Fos via receptor de dopamina e NMDA (Liste et al., 1997). Smith et al. (2005) demonstraram que os receptores dopaminérgicos encontram-se aumentados e são responsáveis por promover regulação positiva na síntese local de receptores do tipo AMPA. Ao aplicarem agonista dos receptores D1/D5 em dendritos houve aumento na frequência de correntes espontâneas excitatórias pós-sinápticas, seguido de acréscimo endógeno na síntese de GluR1 (Smith et al., 2005).

Assim, o acréscimo demonstrado para GluR1 apenas em COR15 na análise de immunoblotting em nosso etudo pode estar associado ao acréscimo endógeno na síntese de GluR1, podendo ainda essa subunidade não estar ancorada na 
membrana. Além disso, GluR1 já foi descrita como tendo papel direto na plasticidade sináptica, em particular nos neurônios que se projetam para o $\mathrm{GPe}$, que participam do aprendizado motor (Deng et al., 2007). Estes autores demonstraram que apenas as eferências que se projetam para o GPe a partir do estriado apresentaram maior proporção de células GluR1-positivas em relação às GluR2-positivas. O GPe recebe a maioria das entradas corticais da via descendente do trato piramidal ipsolateral, ou seja, da camada $V$ do córtex cerebral, enquanto GPi e SNr, que têm menos GluR1, recebem projeções bilaterais das camadas 3 e 5 do córtex (Reiner et al., 2003). Wright et al. (2001) demonstraram que a plasticidade corticoestriatal ocorre de fato apenas com a estimulação ipsolateral (via do GPe) por induzir LTP no estriado, aumentando a expressão de GluR1.

A presença de mais subunidades GluR1 e ausência de canais que contenham GluR2 produz maior condutância pelos canais iônicos e assim dessensibilização mais rápida, por apresentarem maior influxo de $\mathrm{Ca}^{2+}$ após ativação cortical. Assim, há uma contribuição dos neurônios estriado-GPe, que expressam mais GluR1, na plasticidade corticoestriatal envolvida no refinamento do movimento durante 0 processo de aprendizagem processual (Reiner et al., 2003; Plant et al., 2006).

Podemos sugerir que 0 nosso protocolo favoreceu a interação glutamato/dopamina e consequentemente potencialização na síntese de GluR1, e possivelmente induziu plasticidade; porém, esta mudança na expressão de GluR1 provavelmente ocorreu no período entre 7 e 15 dias de atividade física e não especificamente no $15^{\circ}$ dia. Possivelmente o maior aumento de GluR1 foi de neurônios da via estriado-GPe, principal alvo das fibras provenientes do córtex motor, promovendo assim possivelmente uma plasticidade neural. No entanto, as subunidades GluR2/3 não sofrem mudanças por não terem participação fundamental na plasticidade corticoestriatal (Martin et al., 1993; Tallaksen-Greene e Albin, 1994). As mudanças na expressão de subunidades dos GluRs em nosso estudo complementam outros estudos que sugerem que a diferença na densidade póssináptica e no estado de fosforilação de GluR1 e GluR2 possivelmente são os fatores responsáveis por promover plasticidade nos neurônios estriado-GPe (Song e Huganir, 2002; Terashima et al., 2004). 


\section{CONCLUSÕES}

Os nossos dados corroboram os estudos realizados em humanos que sugerem haver uma reestruturação neurofisiológica do organismo após treino motor, promovendo benefícios de base estrutural da circuitaria neuronal que se alteram com o tempo (Baumeister et al., 2008). Assim, o exercício físico por curto período de tempo foi capaz de promover alterações plásticas ao longo do treinamento de forma distinta nas estruturas e subunidades estudadas, sugerindo uma participação específica de cada subunidade em cada estrutura e tempo de treino. Com os dados obtidos em nosso estudo podemos entender um pouco melhor as mudanças centrais que ocorrem após o treino físico agudo, as quais podem provomer alterações na resposta motora. 


\section{REFERÊNCIAS BIBLIOGRÁFICAS}

Albin RL, Young AB, Penney JB. The functional anatomy of disorders of the basal ganglia. Trends Neurosci. 1995 Feb; 18(2):63-4.

Alexander GE, Crutcher MD. Functional architecture of basal ganglia circuits: neural substrates of parallel processing. Trends Neurosci. $1990 \mathrm{Jul} ; 13(7): 266-71$.

Andersson U, Treebak JT, Nielsen JN, Smith KL, Abbott CR, Small CJ, Carling D, Richter EA. Exercise in rats does not alter hypothalamic AMP-activated protein kinase activity. Biochem Biophys Res Commun. 2005 Apr; 329(2):719-25.

Anchisi D, Scelfo B, Tempia F. Postsynaptic currents in deep cerebellar nuclei. J Neurophysiol. 2001 Jan; 85(1):323-31.

Andersen P.; Morris R.; Amaral D.; Bliss T.; O'Keefe J. The Hippocampus Book. Hardcover: Oxford University Press, 2007; 249-254.

Ang ET, Dawe GS; Wong PT; Moochhala S; Ng YK. Alterations in spatial learning and memory after forced exercise. Brain Res. 2006 Aug, 1113 (1):186-93.

Arida RM, Cavalheiro EA, da Silva AC, Scorza FA. Physical activity and epilepsy: proven and predicted benefits. Sports Med. 2008; 38(7):607-615.

Arida RM, Sanabria ERG, Silva AC, Faria LC, Cavalheiro EA. Physical traning reverts hippocampal electrophysiological changes in rats submitted to the pilocarpine model of epilepsy. Physiol Behav. 2004; 83:165-171.

Arida RM, Scorza FA, Santos NF, Peres CA, Cavalheiro EA. Effect of physical exercise on seizure occurrence in a modelo f lobe epilepsy in rats. Epilepsy Res. $1999 ; 37(1): 45-52$.

Asanuma H. The motor cortex. New York: Raven Press, 1989.

Asanuma H., Babb RS., Mori A., Waters RS. Input-output relationship in cat's motor cortex after pyramidal section. J Neurophysiology .1981; 46:694-703.

Asztély F.; Gustafsson B. Ionotropic glutamate receptors. Their possible role in the expression of hippocampal synaptic plasticity. Mol Neurobiol. 1996 Feb; 12(1):1-11.

Aumann TD. Cerebello-thalamic synapses and motor adaptation. Cerebellum. 2002 Jan-Mar; 1(1):69-77.

International Committee of Medical Journal Editors. Uniform

requirements for manuscripts submitted to Biomedical Journal:

sample references. c2003 - [updated 2005 June 15; cited 2006 May

16]. Available from:

http://www.nlm.nih.gov/bsd/uniform requirements.html.

National Library of Medicine. List of journals indexed in Index

Medicus. 2006. Available from: http://www.ncbi.nlm.nih.gov/entrez/;

http://www.nlm.nih.qov/tsd/serials/lii.html. 
Aumann TD, Horne MK. Ultrastructural change at rat cerebellothalamic synapses associated with volitional motor adaptation. J Comp Neurol. 1999 Jun 21;409(1):7184.

Bahn S, Volk B, Wisden W. Kainate receptor gene expression in the developing rat brain. J Neurosci. 1994 Sep, 14(9):5525-47.

Banke TG.; Bowie D.; Lee H.; Huganir RL.; Schousboe A.; Traynelis S.F. Control of GluR1 AMPA receptor function by cAMP-dependent protein kinase. J Neurosci. 2000 Jan 1;20(1):89-102.

Bass BL. RNA editing by adenosine deaminases that act on RNA. Annu Rev Biochem. 2002;71:817-846.

Batista SS; Pires RS; Britto, LRG. Diffrential expression of AMPA- type glutamate receptor subunits during development of the chick optic tectum. Braz J Med Biol Res, 2002 Aug, 35(8): 973-8.

Bear MF, Kirkwood A. Neocortical long-term potentiation. Curr Opin Neurobiol. 1993 Apr;3(2):197-202.

Bear MF, Connors BW, Paradiso MA. Mecanismos moleculares do aprendizado e da memória. In: Bear MF, Connors BW, Paradiso MA. Neurociências: desvendando o Sistema Nervoso Central. 2.ed. Rio de Janeiro: Artmed, 2001. Cap.24, p. 776-807.

Benedetti MG, Gasparroni V, Stecchi S, Zilioli R, Straudi S, Piperno R. Treadmill exercise in early multiple sclerosis: a case series study. Eur $\mathrm{J}$ Phys Rehabil Med. 2009 Jan 21.

Bennett BD, Callaway JC, Wilson CJ. Intrinsic membrane properties underlying spontaneous tonic firing in neostriatal cholinergic interneurons. J Neurosci. 2000 Nov 15;20(22):8493-503.

Berchtold NC, Chinn G, Chou M, Kesslak JP, Cotman CW. Exercise primes a molecular memory for brain-derived neurotrophic factor protein induction in the rat hippocampus. Neuroscience. 2005;133(3):853-61.

Berchtold NC, Kesslak JP, Cotman CW. Hippocampal brain-derived neurotrophic factor gene regulation by exercise and the medial septum. J Neurosci Res. 2002 Jun;68(5):511-21.

Bergles DE, Roberts JD, Somogyi P, Jahr CE. Glutamatergic synapses on oligodendrocyte precursor cells in the hippocampus. Nature. 2000 May $11 ; 405(6783): 187-191$.

Bettler B; Mulle C. Neurotransmitter receptors II: AMPA and kainate receptors. Neuropharmacology. 1995 Feb, 34(2):123-39, 1995. 
Bettler B; Egerbjerg J; Sharma G; Pecht G; Hermans-Borgmeyer I; Moll C; Stevens CF; Heinemann S. Cloning of a putative glutamate receptor: a low affinity kainatebinding subunit. Neuron. 1992 Feb; 8(2):257-65.

Bittencourt LTG. Memória de orientação espacial: avaliação em pacientes com doença de alzheimer e com epilepsia mesial temporal refratária. [Dissertação]. Porto Alegre: Pontifícia Universidade Católica do Rio Grande do Sul; 2005.

Blackstad TW, Brink K, Hem J, Jeune B. Distribution of hippocampal mossy fibers in the rat. An experimental study with silver impregnation methods. J Comp Neurol. 1970 Apr; 138(4):433-49.

Blackstad, T.W. Commissural connections of the hippocampal region in the rat, with special reference to their mode of termination. J Comp Neurol. 1956. 105(3): 417537.

Blandini F, Porter RH, Greenamyre JT. Autoradiographic study of mitochondrial complex $\mathrm{I}$ and glutamate receptors in the basal ganglia of rats after unilateral subthalamic lesion. Neurosci Lett. 1995 Feb 17; 186(2-3):99-102.

Bliss TVP; Collingridge GL. A synaptic model of memory: long-term potentiation in the hippocampus. Nature. 1993; 361:31-39.

Bliss TVP; LФmo T. Long-lasting potentiation of synaptic transmission in the dentate area of the anaesthetized rabbit following stimulation of the perforant path. J.Physiol. 1973; 232: 331-356.

Bochet P, Audinat E, Lambolez B, Crépel F, Rossier J, lino M, Tsuzuki K, Ozawa S. Subunit composition at the single-cell level explains functional properties of a glutamate-gated channel. Neuron. 1994 Feb; 12(2):383-388.

Bolam JP. Synapses of identified neurons in the neostriatum. Ciba Found Symp. 1984; 107:30-47.

Boulter J, Hollmann M; O'Shea-Greenfield A; Hartley, M; Deneris E; Marons C; Heinemann S. Molecular cloning and functional expression of glutamate receptor subunits genes. Science. 1990 Aug 31; 249(4972):1033-7.

Bower JM.; Parsons LM. O Cerebelo Reconsiderado. Scientic American. 2003. 16:66-73.

Bradford MM. A rapid and sensitive method for the quantitation of microgram quantities of protein utilizing the principle of protein-dye binding, Anal Biochem. 1979; 72: 248.

Bredt DS; Nicoll RA. AMPA receptor trafficking at excitatory synapses. Neuron. 2003 Oct 9; 40(2):361-79. 
Brockie PJ; Maricq AV. Building a synapse: genetic analysis of glutamatergic neurotransmission. Biochem Soc Trans. 2006 Feb; 34(Pt 1):64-7.

Brodmann K. Vergleichende Lokalisationslehre der Grosshirnrinde in thren Prinzipien dargestellt auf Grund des Zellenbaues. Leipzig: J.A. Barth, 1909.

Brorson JR, Manzolillo PA, Gibbons SJ, Miller RJ. AMPA receptor desensitization predicts the selective vulnerability of cerebellar Purkinje cells to excitotoxicity. J Neurosci. 1995 Jun; 15(6):4515-24.

Brown DA, Johnson MS, Armstrong CJ, Lynch JM, Caruso NM, Ehlers LB, Fleshner $M$, Spencer RL, Moore RL. Short-term treadmill running in the rat: what kind of stressor is it? J Appl Physiol. 2007 Dec; 103(6):1979-85.

Brown, TH., Zador, AM. The synaptic organization of the brain. Oxford University Press: New York, 1990.

Burnashev N e Rozov A. Genomic control of receptor function. Cell Mol. Life Sci. 2000 Oct; 57(11):1499-507.

Burnashev N, Monyer H, Seeburg PH, Sakmann B. Divalent ion permeability of AMPA receptor channels is dominated by the edited form of a single subunit. Neuron. 1992 Jan; 8(1):189-98.

Calabresi P, Centonze D, Pisani A, Sancesario G, Gubellini P, Marfia GA, Bernardi G. Striatal spiny neurons and cholinergic interneurons express differential ionotropic glutamatergic responses and vulnerability: implications for ischemia and Huntington's disease. Ann Neurol. 1998 May; 43(5):586-97.

Calne, DG. Is idiopatic parkinsonism the consequence of an event or a process? Neurology. Boston. 1994. 44:5-10.

Campos LA, Plehm R, Cipolla-Neto J, Bader M, Baltatu OC. Altered circadian rhythm reentrainment to light phase shifts in rats with low levels of brain angiotensinogen. Am J Physiol Regul Integr Comp Physiol. 2006 Apr; 290(4):R1122-7.

Carpenter MB. Anatomical organization of the corpus striatum and related nuclei. Res Publ Assoc Res Nerv Ment Dis. 1976; 55:1-36.

Carro E; Trejo JL; Busiguina S; Torres-Aleman I. Circulating insulin-like growth factor I mediates the protective effects of physical exercise against brain insults of different etiology and anatomy, J Neurosci. 2001 Aug 1; 21(15):5678-84.

Cechetti F.; Rhod A.; Simão F.; Santin K.; Salbego C.; Netto C.A.; Siqueira I.R. Effect of treadmill exercise on cell damage in rat hippocampal slices submitted to oxygen and glucose deprivation. Brain Res. 2007 Jul 9;1157:121-5. 
Chen WQ, Viidik A, Skalicky M, Höger H, Lubec G. Hippocampal signaling cascades are modulated in voluntary and treadmill exercise rats. Electrophoresis. 2007 Dec; 28(23):4392-400.

Chen Y.W; Chen S.H.; Chou W.; Lo Y.M.; Hung C.H.; Lin M.T. Exercise pretraining protects against cerebral ischaemia induced by heat stroke in rats. Br J Sports Med. 2007 Sep; 41(9):597-602.

Cicchetti F, Prensa L, Wu Y, Parent A. Chemical anatomy of striatal interneurons in normal individuals and in patients with Huntington's disease.

Brain Res Brain Res Rev. 2000 Nov; 34(1-2):80-101.

Cicchetti F, Vinet J, Beach TG, Parent A. Differential expression of alpha-amino-3hydroxy-5-methyl-4-isoxazolepropionate receptor subunits by calretininimmunoreactive neurons in the human striatum. Neuroscience. 1999; 93(1):89-97.

Choi DW. Glutamate neurotoxicity and diseases of the nervous system. Neuron. 1988 Oct; 1(8):623-34.

Ciabarra A.M.; Sullivan J.M.; Gahn L.G.; Pecht G.; Heinemann S.; Sevarino K.A. Cloning and characterization of chi-1: a developmentally regulated member of a novel class of the ionotropic glutamate receptor family. J Neurosci. 1995 Oct; 15(10):6498-6508.

Chalmers DT, Dewar D, Graham DI, Brooks DN, McCulloch J. Differential alterations of cortical glutamatergic binding sites in senile dementia of the Alzheimer type. Proc Natl Acad Sci U S A. 1990 Feb;87(4):1352-1356.

Chepkova AN, Sergeeva OA, Haas HL. Carbenoxolone impairs LTP and blocks NMDA receptors in murine hippocampus. Neuropharmacology. 2008 May 8.

Chiodera P, Volpi R, Maffei ML, Caiazza A, Caffarri G, Papadia C, Alfano F, Capretti $L$, Pagani D, Coiro V. Role of GABA and opioids in the regulation of the vasopressin response to physical exercise in normal men. Regul Pept. 1993 Nov 19; 49(1):57-63.

Christine C.W.; Choi D.W. Effect of zinc on NMDA receptor-mediated channel currents in cortical neurons. J Neurosci. 1990 Jan; 10(1):108-116.

Chu CJ, Jones TA. Experience-dependent structural plasticity in cortex heterotopic to focal sensorimotor cortical damage. Exp Neurol. 2000 Dec; 166(2):403-14.

Claiborne BJ, Amaral DG, Cowan WM. Quantitative, three-dimensional analysis of granule cell dendrites in the rat dentate gyrus. J Comp Neurol. 1990 Dec; 302(2):206-19.

Contarteze RV, Manchado Fde B, Gobatto CA, De Mello MA. Stress biomarkers in rats submitted to swimming and treadmill running exercises. Comp Biochem Physiol A Mol Integr Physiol. 2008 Nov; 151(3):415-22. 
CotmanCW, Engesser-Cesar C. Exercise enhances and protects brain function. Exerc Sport Sci Rev. 2002 Apr; 30(2):75-9.

Cotman CW, Monaghan DT, Ganong AH. Excitatory amino acid neurotransmission: NMDA receptors and Hebb-type synaptic plasticity. Annu Rev Neurosci. 1988;11:6180.

Crews F.T.; Nixon K.; Wilkie M.E. Exercise reverses ethanol inhibition of neural stem cell proliferation. Alcohol. 2004 May; 33(1):63-71.

Curtis DR e Watkins JC. The excitation and depression of spinal neurones by structurally related amino acids. J. Neurocherm. 1960 Sep; 6:117-41.

Czuro A; Hirase H; Csicsvari J; Buzsaki G. Sustained activation of hippocampal pyramidal cells by 'space clamping' in a running Wheel. Eur J Neurosci. 1999 Jan; 11(1):344-52.

Das S.; Sasaki Y.F.; Rothe T.; Premkumar L.S.; Takasu M.; Crandall J.E.; Dikkes P.; Conner D.A.; Rayudu P.V.; Cheung W.; Vincent Chen H-S; Lipton S.A.; Nakanishi N. Increased NMDA current and spine density in mice lacking the NMDA receptor subunit NR3A. Nature. 1998; 393:377-381.

Daussin FN, Zoll J, Ponsot E, Dufour SP, Doutreleau S, Lonsdorfer E, VenturaClapier R, Mettauer B, Piquard F, Geny B, Richard R. Training at high exercise intensity promotes qualitative adaptations of mitochondrial function in human skeletal muscle. J Appl Physiol. 2008 May; 104(5):1436-41.

Delgado- Garcia, J.M. Structure and function of the cerebellum. Rev Neurol. 2001. 33 (7):635-642.

Deng YP, Xie JP, Wang HB, Lei WL, Chen Q, Reiner A. Differential localization of the GluR1 and GluR2 subunits of the AMPA-type glutamate receptor among striatal neuron types in rats. J Chem Neuroanat. 2007 Jul;33(4):167-92.

Dietrich MO; Mantese CE; Porciuncula LO; Ghisleni G; Vinade L; Souza DO; Portela LV. Exercise affects glutamate receptors in postsynaptic densities from cortical mice brain. Brain Res. 2005 Dec 14; 1065(1-2):20-5.

Ding YH, Li J, Zhou Y, Rafols JA, Clark JC, Ding Y. Cerebral angiogenesis and expression of angiogenic factors in aging rats after exercise. Curr Neurovasc Res. 2006 Feb; 3(1):15-23.

Ding Y, Li J, Luan X, Ding YH, Lai Q, Rafols JA, Phillis JW, Clark JC, Diaz FG. Exercise pre-conditioning reduces brain damage in ischemic rats that may be associated with regional angiogenesis and cellular overexpression of neurotrophin. Neuroscience. 2004; 124(3):583-91. 
Ding YH, Luan XD, Li J, Rafols JA, Guthinkonda M, Diaz FG, Ding Y. Exerciseinduced overexpression of angiogenic factors and reduction of ischemia/reperfusion injury in stroke. Curr Neurovasc Res. 2004 Dec; 1(5):411-20.

Ding Y; Ding YH; Luan X; Phillis JW; Diaz FG. Neuroprotective effect of exerciseinduced angiogenic factors on ischemia/reperfusion injury in stroke. Stroke. 2004. $35: 273$.

Ding Y, Li J, Lai Q, Azam S, Rafols JA, Diaz FG. Functional improvement after motor training is correlated with synaptic plasticity in rat thalamus. Neurol Res. 2002 Dec; 24(8):829-36.

Dingledine R; Conn PJ. Peripheral glutamate receptors: molecular biology and role in taste sensation. J Nutr. 2000 Apr; 130(4S Suppl):1039S-42S.

Dingledine R.; Borges K.; Bowie D.; Traynelis S.F. The glutamate receptor ion channels. Pharmacol Rev. 1999 Mar; 51(1):7-61.

Dingledine R, Boland LM, Chamberlin NL, Kawasaki K, Kleckner NW, Traynelis SF, Verdoorn TA. Amino acid receptors and uptake systems in the mammalian central nervous system. Crit Rev Neurobiol. 1988; 4(1):1-96.

Dishman RK, Berthoud HR, Booth FW, Cotman CW, Edgerton VR, Fleshner MR, Gandevia SC, Gomez-Pinilla F, Greenwood BN, Hillman CH, Kramer AF, Levin BE, Moran TH, Russo-Neustadt AA, Salamone JD, Van Hoomissen JD, Wade CE, York DA, Zigmond MJ. Neurobiology of exercise. Obesity (Silver Spring). 2006 Mar;14(3):345-56.

Dishman RK. Brain monoamines, exercise, and behavioral stress: animal models. Med Sci Sports Exerc. 1997 Jan;29(1):63-74.

Doyle DA, Morais Cabral J, Pfuetzner RA, Kuo A, Gulbis JM, Cohen SL, Chait BT, MacKinnon R. The structure of the potassium channel: molecular basis of $\mathrm{K}+$ conduction and selectivity. Science. 1998 Apr 3;280(5360):69-77.

Dustman RE, Emmerson RY, Rushling RO, Shearer DE, Steinhaus LA, Johnson SC, et al. Age and fitness effects on EEG, ERPs, visual sensitivity and cognition. Neurobiol Aging. 1990;11:193-200.

Duvoisin, RM.; Zhang, C.; Ramonell, K. A novel metabotropic glutamate receptor expressed in the retina and olfactory bulb. J Neurosci, 1995. 15: 3075-3083.

Eadie BD, Redila VA, Christie BR. Voluntary exercise alters the cytoarchitecture of the adult dentate gyrus by increasing cellular proliferation, dendritic complexity, and spine density. J Comp Neurol. 2005 May 23; 486(1):39-47.

Eccles J.C. The Physiology of Synapses. Academic Press: New York, 1964. 
Eccles J.C. Neurogenesis and Morphogenesis in the Cerebellar Cortex. Proceeding of the National Academy of Sciences. 1970. 66(2):294-301.

Edgerton VR, Tillakaratne NJT, Bigbee AJ, deLeon RD, Roy RR. Plasticity of the spinal circuitry after injury. Annu Rev Neurosci. 2004; 27:145-67.

Ehlers M.D. Reinsertion or degradation of AMPA receptors determined by activitydependent endocytic sorting. Neuron. 2000 Nov; 28(2):511-525.

Eliot. Estresse e Coração. Rio de Janeiro: Revinter, 1992.

Eric S. Guire, Michael C. Oh, Thomas R. Soderling, and Victor A. Derkach . Recruitment of Calcium-Permeable AMPA Receptors during Synaptic Potentiation Is Regulated by CaM-Kinase I. Journal of Neuroscience. June 4, 2008. 28(23):60006009;

Eriksen HR, Ellertsen B, Gronningsaeter H, Nakken KO, Loyning Y, Ursin H. Physical exercise in women with intractable epilepsy. Epilepsia 1994; 35(6):1256-1264.

Fabel K, Kempermann G. Physical activity and the regulation of neurogenesis in the adult and aging brain. Neuromolecular Med. 2008;10(2):59-66.

Fadie B.D.; Redila V.A.; Christie B.R. Voluntary exercise alters the cytoarchitecture of the adult dentate gyrus by increasing cellular proliferation, dendritic complexity, and spine density. J Comp Neurol. 2005 May 23;486(1):39-47.

Farmer J, Zhao X, van Praag H, Wodtke K, Gage FH, Christie BR. Effects of voluntary exercise on synaptic plasticity and gene expression in the dentate gyrus of adult male Sprague-Dawley rats in vivo. Neuroscience. 2004;124(1):71-9.

Fearnley J.; Less AJ. Parkinson's Disease: neuropathology. Brain, Oxford. 1991. 114:2283-2301.

Figueredo-Cardenas G, Morello M, Sancesario G, Bernardi G, Reiner A. Colocalization of somatostatin, neuropeptide $\mathrm{Y}$, neuronal nitric oxide synthase and NADPH-diaphorase in striatal interneurons in rats. Brain Res. 1996 Oct ; 735(2):31724.

Flora Filho R.; Zilberstein B. Óxido Nítrico: o simples mensageiro percorrendo a complexidade. Metabolismo, síntese e funções. Rev Ass Méd Brasil. 2000; 46(3):265-271.

Franciosi S. AMPA receptors: potential implications in development and disease. Cell Mol Life Sci. 2001 Jun; 58(7):921-30.

Franklin KBJ.; Paxinos G. The mouse brain in stereotaxic coordinates. San Diego: Academic Press, 1997. 
Freund TF, Buzsáki G. Interneurons of the hippocampus. Hippocampus. $1996 ; 6(4): 347-470$.

Fritsch G, Hitzig E. Ueber die elektrische Erregbarkeit des Grosshirns. Arch Anat Physiol Wiss Med 1870; 37:300-332.

Fujise N; Liu NY; Hori N; Kosaka T. Distribuition of calretinin immunoreactivity in the mouse dentate gyrus: II. Mossy cells, with special reference to their dorsoventral difference in calretinin immunoreactivity. Neuroscience. 1998. 82 (1): 181-200.

Fukunaga K, Muller D, Miyamoto E. Increased phosphorylation of Ca2+/calmodulindependent protein kinase II and its endogenous substrates in the induction of longterm potentiation. J Biol Chem. 1995 Mar 17; 270(11):6119-24.

Fukuyama H, Ouchi Y, Matsuzaki S, Nagahama Y, Yamauchi H, Ogawa M, Kimura J, Shibasaki H. Brain functional activity during gait in normal subjects: a SPECT study. Neurosci Lett. 1997. 228:183-186.

Gao J, Maison SF, Wu X, Hirose K, Jones SM, Bayazitov I, Tian Y, Mittleman G, Matthews DB, Zakharenko SS, Liberman MC, Zuo J.Orphan glutamate receptor delta1 subunit required for high-frequency hearing. Mol Cell Biol. 2007 Jun; 27(12):4500-4512.

Garthwaite J. Glutamate, nitric oxide and cell-cell signalling in the nervous system. Trends Neurosci. 1991 Feb; 14(2):60-7.

Gauck V, Jaeger D. The contribution of NMDA and AMPA conductances to the control of spiking in neurons of the deep cerebellar nuclei. J Neurosci. 2003 Sep; 23(22):8109-18.

Geiger JR, Melcher T, Koh DS, Sakmann B, Seeburg PH, Jonas P, Monyer H. Relative abundance of subunit mRNAs determines gating and Ca2+ permeability of AMPA Receptors in principal neurons and interneurons in rat CNS. Neuron. $1995 \mathrm{Jul}$; 15(1):193-204.

Genoux D, Montgomery JM. Glutamate receptor plasticity at excitatory synapses in the brain. Clin Exp Pharmacol Physiol. 2007 Oct; 34(10):1058-63.

Gentile AM, Beheshti Z, Held JM. Enrichment versus exercise effects on motor impairments following cortical removals in rats. Behav Neural Biol. 1987 May; 47(3):321-32.

Gerfen CR; Wilson CJ. The basal ganglia. In: Swanson LW; Bjoklund A; Hokfelt T. Handbook of Chemical Neuroanatomy, vol.12, Integrated System of the CNS. Pat 3. Elsevier, Amsterdam. 1996: 371-468.

Gerfen CR. Synaptic organization of the striatum. J Electron Microsc Tech. 1988 Nov; 10(3):265-81. 
Goldman PS, Nauta WJ. An intricately patterned prefronto-caudate projection in the rhesus monkey. J Comp Neurol. 1977 Feb ; 72(3):369-86.

Gomez-Pinilla F, Ying Z, Roy RR, Molteni R, Edgerton VR. Voluntary exercise induces a BDNF-mediated mechanism that promotes neuroplasticity. J Neurophysiol. 2002 Nov; 88(5):2187-95.

Graybiel AM. Neurotransmitters and neuromodulators in the basal ganglia.

Trends Neurosci. 1990 Jul; 13(7):244-54.

Graybiel AM e Ragsdale CW. In: Emson, PC, editor Chemical Neuroanatomy. New York: Raven Press, 1983:427-504.

Grealy MA, Johnson DA, Rushton SK. Improving cognitive function after brain injury: the use of exercise and visual reality. Arch Phys Med Rehabil. 1999; 80:661-7.

Griesbach GS, Gomez-Pinilla F, Hovda DA. The upregulation of plasticity-related proteins following TBI is disrupted with acute voluntary exercise. Brain Res. 2004a Aug; 1016(2):154-62.

Griesbach GS, Hovda DA, Molteni R, Wu A, Gomez-Pinilla F. Voluntary exercise following traumatic brain injury: brain-derived neurotrophic factor upregulation and recovery of function. Neuroscience. 2004b; 125(1):129-39.

Griffiths S, Scott H, Glover C, Bienemann A, Ghorbel MT, Uney J, Brown MW, Warburton EC, Bashir ZI. Expression of long-term depression underlies visual recognition memory. Neuron. 2008 Apr 24; 58(2):186-194.

Grooms SY, Noh KM, Regis R, Bassell GJ, Bryan MK, et al. Activity bidirectionally regulates AMPA receptor mRNA abundance in dendrites of hippocampal neurons. J. Neurosci. 2006. 26:8339-51.

Gu JG, Albuquerque C, Lee CJ, MacDermott AB.Synaptic strengthening through activation of Ca2+-permeable AMPA receptors. Nature. 1996 Jun; 381(6585):793796.

Han ZS, Buhl EH, Lörinczi Z, Somogyi P. A high degree of spatial selectivity in the axonal and dendritic domains of physiologically identified local-circuit neurons in the dentate gyrus of the rat hippocampus. Eur J Neurosci. 1993 May 1; 5(5):395-410.

Hanley JG, Henley JM. Picking out the details of cerebellar LTD. Neuron. 2006 Mar $16 ; 49(6): 778-80$.

Hanna M, Fins JJ. Viewpoint: power and communication: why simulation training ought to be complemented by experiential and humanist learning. Acad Med. 2006 Mar, 81(3):265-270.

Harms KJ, Rioult-Pedotti MS, Carter DR, Dunaevsky A. Transient spine expansion and learning-induced plasticity in layer 1 primary motor cortex. J Neurosci. 2008 May; 28(22):5686-5690. 
Hattori S, Naoi M, Nishino H. Striatal dopamine turnover during treadmill running in the rat: relation to speed of running. Brain Res Bull. 1994. 35:41-49.

Hayashi T. A physiological study of epileptic seizures following cortical stimulation in animals and its application to human clinics. J.Physiol. 1952 Nov; 3(1):46-64.

Hebb D. The Organization of Behavior. New York: Willey, 1949.

Henriksson J. Effect of exercise on amino acid concentrations in skeletal muscle and plasma. J Exp Biol. 1991 Oct;160:149-65.

Hirata $\mathrm{R}$, Togashi $\mathrm{H}$, Matsumoto $\mathrm{M}$, Yamaguchi T, Izumi T, Yoshioka $\mathrm{M}$. Characterization of stress-induced suppression of long-term potentiation in the hippocampal CA1 field of freely moving rats. Brain Res. 2008 Jun 11.

Hollmann M; O'Shea-Greenfield A.; Rogers SW; Heinemann S. Cloning by functional expression of a member of the glutamate receptor family. Nature. 1989 Dec 7; 342(6250):643-8.

Hollmann M, Heinemann S. Cloned glutamate receptors. Annu Rev Neurosci. 1994; 17:31-108.

Holmes MM, Galea LA, Mistlberger RE, Kempermann G. Adult hippocampal neurogenesis and voluntary running activity: circadian and dose dependent effects. $J$ Neurosci Res. 2004 Apr;76(2):216-22.

Holschneider DP.; Yang J.; Guo Y.; Maarek J.M.I. Reorganization of functional brain maps after exercise training: Importance of cerebellar-thalamic-cortical pathway. Brain Research. 2007 Dec 12; 1184:96-107.

Holschneider DP, Maarek JM, Yang J, Harimoto J, Scremin OU. Functional brain mapping in freely moving rats during treadmill walking. J Cereb Blood Flow Metab. 2003 Aug; 23(8):925-32.

Hu H; Real E; Takamiya K; Kang MG; Ledoux J; Huganir RL; Malinow R. Emotion enhances learning via norepinephrine regulation of AMPA-receptor trafficking. Cell. 2007. 131(1):160-173.

Hu S, Ying Z, Gomez-Pinilla F, Frautschy SA. Exercise can increase small heat shock proteins (sHSP) and pre- and post-synaptic proteins in the hippocampus. Brain Res. 2009 Jan 16;1249:191-201.

Hua L, Brown CA Dr, Hains S, Godwin M, Parlow J. Effects of Low-Intensity Exercise Conditioning on Blood Pressure, Heart Rate, and Autonomic Modulation of Heart Rate in Men and Women with Hypertension. Biol Res Nurs. 2009 Jan 15.

Huang AM, Jen CJ, Chen HF, Yu L, Kuo YM, Chen HI. Compulsive exercise acutely upregulates rat hippocampal brain-derived neurotrophic factor. J Neural Transm. 2006 Jul;113(7):803-11. 
Huntley GW; Vickers JC; Janssen W; Brose N; Heinemann SF; Morrison JH. Distribution and synaptic localization of immunocytochemically identified NMDA receptor subunit proteins in sensory-motor and visual cortices of monkey and human. J. Neurosci. 1994a; 14:3603-3619.

Huntley GW; Vickers JC; Morrison JH. Cellular and synaptic localization of NMDA and non-NMDA receptor subunits in neocortex: organization features related to cortical circuitry, function and disease. Trends Neurosci. 1994b; 17, 536-543.

Isa T, Itazawa S, lino M, Tsuzuki K, Ozawa S. Distribution of neurones expressing inwardly rectifying and $\mathrm{Ca}(2+)$-permeable AMPA receptors in rat hippocampal slices. J Physiol. 1996 Mar 15; 491 ( Pt 3):719-733.

Isaacs KR, Anderson BJ, Alcantara AA, Black JE, Greenough WT. Exercise and the brain: angiogenesis in the adult rat cerebellum after vigorous physical activity and motor skill learning. J Cereb Blood Flow Metab. 1992 Jan;12(1):110-9. Erratum in: J Cereb Blood Flow Metab 1992 May; 12(3):533.

Ishide T, Maher TJ, Pearce WJ, Nauli SM, Chaiyakul P, Ally A. Simultaneous glutamate and gamma-aminobutyric acid release within ventrolateral medulla during skeletal muscle contraction in intact and barodenervated rats. Brain Res. 2001 Dec $27 ; 923(1-2): 137-46$.

Ishide T, Nauli SM, Maher TJ, Ally A. Cardiovascular responses and neurotransmitter changes following blockade of nNOS within the ventrolateral medulla during static muscle contraction. Brain Res. 2003 Jul; 977(1):80-9.

Ishide T, Preuss CV, Maher TJ, Ally A. Neurochemistry within ventrolateral medulla and cardiovascular effects during static exercise following eNOS antagonism. Neurosci Res. 2005 May; 52(1):21-30.

Itazawa SI, Isa T, Ozawa S. Inwardly rectifying and Ca2+-permeable AMPA-type glutamate receptor channels in rat neocortical neurons. J Neurophysiol. $1997 \mathrm{Nov}$; 78(5):2592-2601.

Ito M. The molecular organization of cerebellar long-term depression. Nature. 2002. 3:896-902.

Ito, M. Mechanisms of motor learning in the cerebellum. Brain Res. 2000; 886:237245.

Ito M. Long-term depression as a memory process in the cerebellum. Neurosci Res. 1986 Sep; 3(6):531-9.

Jayakar SS; Dikshit M. AMPA receptor regulation mechanisms: future target for safer neuroprotective drugs. Int J Neurosci. 2004 Jun; 114(6): 695-734. 
Jeneson JA, de Snoo MW, Verlinden NA, Joosten BJ, Doornenbal A, Schot A, Everts ME. Treadmill but not wheel running improves fatigue resistance of isolated extensor digitorum longus muscle in mice. Acta Physiol 2007 Jun; 190(2):151-61.

Jiang X, Tian F, Mearow K, Okagaki P, Lipsky RH, Marini AM. The excitoprotective effect of N-methyl-D-aspartate receptors is mediated by a brain-derived neurotrophic factor autocrine loop in cultured hippocampal neurons. J Neurochem. 2005 Aug; 94(3):713-22.

Jonas P, Racca C, Sakmann B, Seeburg PH, Monyer H. Differences in Ca2+ permeability of AMPA-type glutamate receptor channels in neocortical neurons caused by differential GluR-B subunit expression. Neuron. 1994 jun;12(6):12811289.

Joyal CC, Meyer C, Jacquart G, Mahler P, Caston J, Lalonde R. Effects of midline and lateral cerebellar lesions on motor coordination and spatial orientation. Brain Res. 1996 Nov 11; 739(1-2):1-11.

Kajekar R, Chen CY, Mutoh T, Bonham AC. GABA(A) receptor activation at medullary sympathetic neurons contributes to postexercise hypotension. Am J Physiol Heart Circ Physiol. 2002 May; 282(5):H1615-24.

Kakegawa W, Miyazaki T, Emi K, Matsuda K, Kohda K, Motohashi J, Mishina M, Kawahara S, Watanabe M, Yuzaki M. Differential regulation of synaptic plasticity and cerebellar motor learning by the C-terminal PDZ-binding motif of GluRdelta2. J Neurosci. 2008 Feb 6; 28(6):1460-8.

Kandel ER; Schwartz JH; Jessell TM. Princípios da Neurociência. Ed. Manole. 4ํㅡㄹ ed. São Paulo, 2003.

Kandel ER, Schwartz JH, Jessel TM. Mecanismos Celulares do Aprendizado e da Memória. Fundamentos da Neurociência a do Comportamento. 4th. Ed. California: McGraw-Hill, 2000.

Kandel ER, Schwartz JH, Jessel TM. Principles of Neural Science. 4th.ed. California: McGraw-Hill, 2000.

Kashiwabuchi N.; Ikeda K.; Araki K.; Hirano T.; Shibuki K.; Takayama C.; Inoue Y.; Kutsuwada T.; Yagi T.; Kang Y.; et al. Impairment of motor coordination, Purkinje cell synapse formation, and cerebellar long-term depression in GluR delta 2 mutant mice. Cell. 1995 Apr 21; 81(2):245-252.

Katz LC, Shatz CJ. Synaptic activity and the construction of cortical circuits. Science. 1996 Nov 15; 274(5290):1133-8.

Kawaguchi Y. Physiological, morphological, and histochemical characterization of three classes of interneurons in rat neostriatum. J Neurosci. 1993 Nov; 13(11):490823. 
Kawashima $H$, Saito T, Yoshizato H, Fujikawa T, Sato $Y$, McEwen BS, Soya H. Endurance treadmill training in rats alters $\mathrm{CRH}$ activity in the hypothalamic paraventricular nucleus at rest and during acute running according to its period. Life Sci. 2004 Dec 31; 76(7):763-74.

Keinänen K; Wisden W; Sommer B; Werner P; Herb A; Verdoorn TA; Sakmann B; Seeburg PH. A family of AMPA-selective glutamate receptors. Science. 1990; 249: 556-560.

Kempermann G; Gage FH. Genetic determinants of adult hippocampal neurogenesis correlate with acquisition, but not probe trial performance in the water maze task. Eur J Neurosci. 2002. 16:129-136.

Kempermann G.; van Praag H.; Gage F.H. Activity-dependent regulation of neuronal plasticity and self repair. Prog Brain Res. 2000; 127:35-48.

Kempermann G, Kuhn HG, Gage FH. Experience-induced neurogenesis in the senescent dentate gyrus. J Neurosci. 1998 May 1; 18(9):3206-12.

Kempermann G, Kuhn HG, Gage FH. More hippocampal neurons in adult mice living in an enriched environment. Nature. 1997 Apr 3; 386(6624):493-5.

Kew JNC; Kemp JA. Ionotropic and metabotropic glutamate receptor struture and pharmacology. Psychopharmacology. 2005 Apr; 179(1):4-29.

Kim Y.P.; Kim H.; Shin M.S.; Chang H.K., Jang M.H.; Shin C.; Lee H.H.; Lee H.H.; Yoon J.H.; Jeong I.G.; Kim C.J. Age-dependence of the effect of treadmill exercise on cell proliferation in the dentate gyrus of rats. Neuroscience Letters. 2004 Jan; 355(1-2):152-154.

Kim JJ e Diamond DM. The stressed hippocampus, synaptic plasticity and lost memories. Nat Rev Neurosci. 2002. 3:453-462.

Kimelberg HK; Jalonen TO; Aoki C; McCarthy K. Transmitter receptor and uptake systems in astrocytes and their relation to behaviour. In: Glial Cells: Their Role in Behaviour. 1998, p. 107-129.

Kind PC; Neumann PE. Plasticity: downstream of glutamate. Trends Neurosci. 2001 Oct; 24(10):553-5.

Kindlundh-Högberg AM, Blomqvist A, Malki R, Schiöth HB. Extensive neuroadaptive changes in cortical gene-transcript expressions of the glutamate system in response to repeated intermittent MDMA administration in adolescent rats. BMC Neurosci. 2008 Apr 17; 9:39.

Kita H. Glutamatergic and GABAergic postsynaptic responses of striatal spiny neurons to intrastriatal and cortical stimulation recorded in slice preparations. Neuroscience. 1996 Feb; 70(4):925-40. 
Kitamura T; Mishina M; Sugiyama $\mathrm{H}$. Enhancement of neurogenesis by running wheel exercises is suppressed in mice lacking NMDA receptor epsilon 1 subunit. Neurosci Res. 2003 Sep; 47(1):55-63.

Kleim JA, Swain RA, Armstrong KA, Napper RM, Jones TA, Greenough WT. Selective synaptic plasticity within the cerebellar cortex following complex motor skill learning. Neurobiol Learn Mem. 1998 May; 69(3):274-89.

Koepp KK, Janot JM. A comparison of VO2max and metabolic variables between treadmill running and treadmill skating. J Strength Cond Res. 2008 Mar; 22(2):497502.

Kohl Z.; Kandasamy M.; Winner B.; Aigner R.; Gross C.; Couillard-Despres S.; Bogdahn U.; Aigner L.; Winkler J. Physical activity fails to rescue hippocampal neurogenesis deficits in the R6/2 mouse model of Huntington's disease. Brain Research. 2007 Jun; 1154:24-33.

Koós T, Tepper JM. Inhibitory control of neostriatal projection neurons by GABAergic interneurons. Nat Neurosci. 1999 May; 2(5):467-72.

Kramár EA, Lin B, Lin CY, Arai AC, Gall CM, Lynch G. A novel mechanism for the facilitation of theta-induced long-term potentiation by brain-derived neurotrophic factor. J Neurosci. 2004 Jun 2; 24(22):5151-61.

Kramer JM, Plowey ED, Beatty JA, Little HR, Waldrop TG. Hypothalamus, hypertension, and exercise. Brain Res Bull. 2000 Sep 1; 53(1):77-85.

Kronengerg G.; Bick-Sander A.; Bunk E.; Wolf C.; Ehninger D.; Kempermann G. Physical exercise prevents age-related decline in precursor cell activity in the mouse dentate gyrus. Neurobiol Aging. 2006 Oct; 27(10): 1505-1513.

Lacerda A.C.; Gripp F.; Rodrigues L.O.; Silami-Garcia E.; Coimbra C.C.; Prado L.S. Acute heat exposure increases high-intensity performance during sprint cycle exercise. Eur J Appl Physiol. 2007 Jan; 99(1):87-93.

Laemmli UK. Cleavage of structural proteins during the assembly of the head of bacteriophage T4. Nature. 1970 Aug;227(5259):680-5.

Lambert TJ, Fernandez SM, Frick KM. Different types of environmental enrichment have discrepant effects on spatial memory and synaptophysin levels in female mice. Neurobiol Learn Mem. 2005 May;83(3):206-16.

Lambolez B, Ropert N, Perrais D, Rossier J, Hestrin S. Correlation between kinetics and RNA splicing of alpha-amino-3-hydroxy-5-methylisoxazole-4-propionic acid receptors in neocortical neurons. Proc Natl Acad Sci U S A. 1996 Mar 5; 93(5):1797802.

Lambolez B, Audinat E, Bochet P, Crépel F, Rossier J. AMPA receptor subunits expressed by single Purkinje cells. Neuron. 1992 Aug; 9(2):247-58. 
Lamprecht R; LeDoux J. Structural plasticity and memory Nat Rev Neurosci. 2004 Jan;5(1):45-54

Larry RS, Kandel ER. Um Mecanismo de Armazenamento Sináptico para a Memória Declarativa. In: Memória da Mente às Moléculas. Porto Alegre: Artmed, 2003.

Larsen JO; Skalicky M; Viidik A. Does long-term phusical exercise counteract agerelated Purkinje cell loss? A stereological study of rat cerebellum. J Comp Neurol. 2000 Dec 11;428(2):213-22.

Laube B; Kuhse J; Betz $\mathrm{H}$. Evidence for tetrameric structure of recombinat NMDA receptors. J. Neurosci. 1998 Apr 15; 18(8):2954-61.

Laurie DJ, Seeburg PH. Regional and developmental heterogeneity in splicing of the rat brain NMDAR1 mRNA. J Neurosci. 1994 May; 14(5 Pt 2):3180-94.

Laurin D, Verreault R, Lindsay J, MacPherson K, Rockwood K. Physical activity and risk of cognitive impairment and dementia in elderly persons. Arch Neurol. 2001; 58:498-504.

Laursen AM. Selective increase in choice latency after transection of a pyramidal tract in monkeys. Brain Res. 1970; 24:544-545.

Laursen AM e Wiesendanger $\mathrm{M}$. The effect of pyramidal lesions on response latency in cats. Brain Res. 1967;91:1-14.

Lawler JM, Powers SK, Visser T, Van Dijk H, Kordus MJ, Ji LL. Acute exercise and skeletal muscle antioxidant and metabolic enzymes: effects of fiber type and age. Am J Physiol. 1993 Dec; 265(6):R1344-50.

Lee HK, Barbarosie M, Kameyama K, Bear MF, Huganir RL. Regulation of distinct AMPA receptor phosphorylation sites during bidirectional synaptic plasticity. Nature. 2000 Jun 22; 405(6789):955-959.

Legendre P.; Westbrook G.L. The inhibition of single N-methyl-D-aspartate-activated channels by zinc ions on cultured rat neurones. J Physiol. 1990 Oct; 429:429-449.

Leggio MG, Mandolesi L, Federico F, Spirito F, Ricci B, Gelfo F, Petrosini L. Environmental enrichment promotes improved spatial abilities and enhanced dendritic growth in the rat. Behav Brain Res. 2005 Aug 30; 163(1):78-90.

Lei W, Jiao Y, Del Mar N, Reiner A. Evidence for differential cortical input to direct pathway versus indirect pathway striatal projection neurons in rats. J Neurosci. 2004 Sep 22;24(38):8289-99.

Leite JP, Cavalheiro EA. Neurobiologia da esclerose medial temporal. In Costa JC, Palmini A, Yacubian EMT, Cavalheiro EA Fundamentos neurobiológicos das epilepsias: aspectos clínicos e cirúrgicos: São Paulo: Lemos Editorial, 1998;129-136. 
Lent R. Neurociência da Mente e do Comportamento. Rio de Janeiro: Editora Guanabara Koogan, 2008, p. 112.

Lent R. Cem Bilhões de Neurônios. Conceitos Fundamentais de Neurociência. São Paulo: Atheneu, 2005.

Leung LY, Tong KY, Zhang SM, Zeng XH, Zhang KP, Zheng XX. Neurochemical effects of exercise and neuromuscular electrical stimulation on brain after stroke: a microdialysis study using rat model. Neurosci Lett. 2006 Apr 10-17; 397(1-2):135-9.

Li J, Ding YH, Rafols JA, Lai Q, McAllister JP, Ding Y. Increased astrocyte proliferation in rats after running exercise. Neurosci Lett. 2005 Oct; 386(3):160-4.

Liepert J.; Hamzei F.; Weiller C. Lesion-induced and training-induced brain reorganization. Restor Neurol Neurosci. 2004;22(3-5):269-77.

Lin S.Y.; Wu K.; Levine E.S.; Mount H.T.; Suen P.C.; Black I.B. BDNF acutely increases tyrosine phosphorylation of the NMDA receptor subunit $2 \mathrm{~B}$ in cortical and hippocampal postsynaptic densities. Brain Res. 1998; 55:20-27.

Limatola C. Neurotrophic effects of AMPA. Cerebellum. 2004; 3(1):2-10.

Lin SY, Wu K, Levine ES, Mount HT, Suen PC, Black IB. BDNF acutely increases tyrosine phosphorylation of the NMDA receptor subunit $2 \mathrm{~B}$ in cortical and hippocampal postsynaptic densities. Brain Res Mol Brain Res. 1998 Mar 30;55(1):2027.

Liste I, Guerra MJ, Caruncho HJ, Labandeira-Garcia JL. Treadmill running induces striatal Fos expression via NMDA glutamate and dopamine receptors. Exp Brain Res. 1997 Jul;115(3):458-68.

Liste I, Rozas G, Guerra MJ, Labandeira-Garcia JL. Cortical stimulation induces Fos expression in striatal neurons via NMDA glutamate and dopamine receptors. Brain Res. 1995 Nov 27;700(1-2):1-12.

Llinas, R.R., 2003. The contribution of Santiago Ramon y Cajal to functional neuroscience. Nat. Rev., Neurosci. 4: 77-80.

Lomeli H.; Sprengel R.; Laurie D.J.; Köhr G.; Herb A.; Seeburg P.H; Wisden W. The rat delta-1 and delta-2 subunits extend the excitatory amino acid receptor family. FEBS Lett. 1993 Jan 11;315(3):318-322.

Lorente de Nó R. Cerebral cortex: architecture, intercortical conections, motor projection. In: Fulton JF, editor. Physiology of the nervous system, 3rd ed. New York: Oxford University Press, 1942; 274-298.

Lorente de Nó, R. Studies of the structure of the cerebral cortex. II. Continuation of the study of the ammonic system. J. Psychol. Neurol. 1934. 46: 113-177. 
Lou SJ, Liu JY, Chang H, Chen PJ. Hippocampal neurogenesis and gene expression depend on exercise intensity in juvenile rats. Brain Res. 2008 May 19;1210:48-55.

Lupinacci NS, Rikli RE, Jones CJ, Ross D. Age and physical activity effects on reaction time and digit symbol substitution performance in cognitively active adults. Research Quartely for Exercise and Sport. 1993; 64:144-150.

Mabandla M, Kellaway L, St Clair Gibson A, Russell VA. Voluntary running provides neuroprotection in rats after 6-hydroxydopamine injection into the medial forebrain bundle. Metab Brain Dis. 2004 Jun;19(1-2):43-50.

Madalosso SH.; Perez-Villegas EM.; Armengol JA. Naturally occurring neuronal death during the postnatal development of Purkinje cells and their precerebellar afferent projections. Brain Res Brain Res Rev. 2005. 49(2):267-279.

Magee JC, Cook EP. Somatic EPSP amplitude is independent of synapse location in hippocampal pyramidal neurons. Nat Neurosci. 2000 Sep;3(9):895-903.

Malenka RC. Synaptic plasticity and AMPA receptor trafficking. Ann N Y Acad Sci. 2003 Nov;1003:1-11.

Manzoni D. The cerebellum and sensorimotor coupling: looking at the problem from the perspective of vestibular reflexes. Cerebellum. 2007;6(1):24-37.

Meftah EM, Rispal-Padel L. Synaptic plasticity in the thalamo-cortical pathway as one of the neurobiological correlates of forelimb flexion conditioning: electrophysiological investigation in the cat. J Neurophysiol. 1994. Dec;72(6):2631-47.

Maren S.; Baudry M. Properties and mechanisms of long-term synaptic plasticity in the mammalian brain: relationships to learning and memory. Neurobiol Learn Mem. 1995 Jan;63(1):1-18.

Mayer ML e Westbrook GL. The physiology of excitatory amino acids in the vertebrate central nervous system. Prog. Neurobiol. 1987, 28: 197-276.

Marin R, Williams A, Hale S, Burge B, Mense M, Bauman R, Tortella F. The effect of voluntary exercise exposure on histological and neurobehavioral outcomes after ischemic brain injury in the rat. Physiol Behav. 2003 Nov;80(2-3):167-75.

Martin LJ; Blackstone CD; Huganir RL; Price DL. The striatal mosaic in primates: striosomes and matrix are differentially enriched in ionotropic glutamate receptor subunits. J Neurosci. 1994b. 13:782-792.

Martin LJ; Blackstone CD; Levey AI; Huganir RL; Price DL. AMPA glutamate receptor subunits are differentially distributed in rat brain. Neurosc. 1993 Mar;53(2):327-58.

Martin LJ, Blackstone CD, Huganir RL, Price DL. The striatal mosaic in primates: striosomes and matrix are differentially enriched in ionotropic glutamate receptor subunits. J Neurosci. 1993 Feb;13(2):782-92. 
Masu, M; Tanabe, Y.; Tsuchida, K.; Shigemoto, R.; Nakanishi, S. Sequence and expression of a metabotropic receptor. Nature, v. 349, p. 760-765, 1991.

Mattson MP. Neuroprotective signaling and the aging brain: take away my food and let me run. Brain Res. 2000; 886:47-53.

Matyas F.; Freund TF.; Gulýas A.I. Immunocytochemically defined interneuron populations in the hippocampus of the mouse strains used in transgenic technology. Hippocampus. 2004. 14:460-481.

Meeusen R, Smolders I, Sarre S, de Meirleir K, Keizer H, Serneels M, Ebinger G, Michotte $\mathrm{Y}$. Endurance training effects on neurotransmitter release in rat striatum: an in vivo microdialysis study. Acta Physiol Scand. 1997 Apr;159(4):335-41.

Meldrum BS. Glutamate as a neurotransmitter in the brain: review of physiology and pathology. J Nutr., 2000, 130: 1007S-1015S.

Mensah PL. The internal organization of the mouse caudate nucleus: evidence for cell clustering and regional variation. Brain Res. 1977 Nov 25;137(1):53-66.

Miale IL.; Sidman RL. An autoradiographic analysis of histogenesis in the mouse cerebellum. Exp Neurol. 1961. 4: 277-296.

Michelini LC. Differential effects of vasopressinergic and oxytocinergic pre-autonomic neurons on circulatory control: reflex mechanisms and changes during exercise. Clin Exp Pharmacol Physiol. 2007 Apr;34(4):369-76.

Mink JW. Basal Ganglia. In: Zigmund MJ; Bloon FE; Lands SC; Roberts JL; Squire LR. Fundamental Neuroscience. San Diego: Academic Press, 1999.

Miyamoto E. Molecular mechanism of neuronal plasticity: induction and maintenance of long-term potentiation in the hippocampus. J Pharmacol Sci. 2006;100(5):433-442.

Molteni R, Wu A, Vaynman S, Ying Z, Barnard RJ, Gomez-Pinilla F. Exercise reverses the harmful effects of consumption of a high-fat diet on synaptic and behavioral plasticity associated to the action of brain-derived neurotrophic factor. Neuroscience. 2004a;123(2):429-40.

Molteni R, Zheng JQ, Ying Z, Gomez-Pinilla F, Twiss JL. Voluntary exercise increases axonal regeneration from sensory neurons. Proc Natl Acad Sci U S A. 2004b Jun 1;101(22):8473-8.

Molteni R, Ying Z, Gomez-Pinilla F. Differential effects of acute and chronic exercise on plasticity-related genes in the rat hippocampus revealed by microarray. Eur $\mathrm{J}$ Neurosci. 2002 Sep;16(6):1107-16.

Monaghan DT; Bridges RJ; Cotman CW. The excitatory amino acid receptors: Their classes, pharmacology, and distinct properties in the function of the central nervous system. Annu. Rev. Pharmacol. Toxicol., 1989;29:365-402. 
Monyer H; Burnashev N; Laurie DJ; Sakmann B; Seeburg PH. Developmental and regional expression in the rat brain and functional properties of four NMDA receptors. Neuron. 1994 Mar;12(3):529-40.

Monyer H; Sprengel R; Schoepfer R; Herb A; Higuchi M; Lomeli H; Burnashev N; Sakmann B; Seeburg PH. Heteromeric NMDA receptors: molecular and functional distinction of subtypes. Science. 1992 May 22;256(5060):1217-21.

Monyer H, Seeburg PH, Wisden W. Glutamate-operated channels: developmentally early and mature forms arise by alternative splicing. Neuron. 1991 May;6(5):799-810.

Mori H. e Mishina M. Neurotransmitter receptors VIII, Structure and function of the NMDA receptor channel. Neuropharmacology. 1995 (34): 1219-1237.

Morgan JI, Curran T. Stimulus-transcription coupling in the nervous system: involvement of the inducible proto-oncogenes fos and jun. Annu Rev Neurosci. $1991 ; 14: 421-51$.

Moriguchi S, Shioda N, Han F, Narahashi T, Fukunaga K. CaM kinase II and protein kinase $\mathrm{C}$ activations mediate enhancement of long-term potentiation by nefiracetam in the rat hippocampal CA1 region. J Neurochem. 2008 May 14.

Mueller PJ. Exercise training and sympathetic nervous system activity: evidence for physical activity dependent neural plasticity. Clin Exp Pharmacol Physiol. 2007 Apr; Vol. 34 (4), pp. 377-84.

Nakanishi S. Molecular diversity of glutamate receptors and implications for brain function. Science 1992 Oct; 258(5082):597-603.

Nauli SM, Maher TJ, Pearce WJ, Ally A. Effects of opioid receptor activation on cardiovascular responses and extracellular monoamines within the rostral ventrolateral medulla during static contraction of skeletal muscle. Neurosci Res. 2001a Dec;41(4):373-83.

Nauli SM, Pearce WJ, Amer A, Maher TJ, Ally A. Effects of nitric oxide and GABA interaction within ventrolateral medulla on cardiovascular responses during static muscle contraction. Brain Res. 2001b Dec;922(2):234-42.

Nauta WJ, Domesick VB. Afferent and efferent relationships of the basal ganglia. Ciba Found Symp. 1984;107:3-29.

Neafsey EJ, Bold EL, Haas G, Hurley-Gius KM, Quirk G, Sievert CF, Terreberry RR. The organization of the rat motor cortex: a microstimulation mapping study. Brain Res. 1986; 11:77-96.

Neeper SA, Gomes-Pinilla F, Choi J, Cotman C. Exercise and brain neurotrophins. Nature. 1997; 373:109. 
Netter FH. Interactive Atlas of Human Anatomy. Nervous System Edition. Novartis 1999.

Nowicka D. Ionotropic glutamate receptor trafficking--there and back again Postepy Biochem. 2006;52(4):351-9. Polish.

Obeso JA, Rodríguez-Oroz MC, Rodríguez M, Lanciego JL, Artieda J, Gonzalo N, Olanow CW. Pathophysiology of the basal ganglia in Parkinson's disease.

Trends Neurosci. 2000 Oct;23(10 Suppl):S8-19.

Obrenovitch, TP; Ureniak, J. Altered glutamatergic transmission in neurological disorders: from high extracellular glutamate to excessive synaptic efficacy. Prog Neurobiol. 1997; 51 (1): 39-87.

Oliff H.S. ; Berchtold N.C. ; Isackson P. ; Cotman C.W. Exercise-induced regulation of brain-derived neurotrophic factor (BDNF) transcripts in the rat hippocampus. Brain Res Mol Brain Res. 1998 Oct 30;61(1-2):147-153.

Olson A.K.; Eadie B.D.; Ernst C.; Christie B.R. Environmental enrichment and voluntary exercise massively increase neurogenesis in the adult hippocampus via dissociable pathways. Hippocampus. 2006;16(3):250-60.

Ottiger HP; Gerfin-Moser A; Principe FD; Dutly F; Streit P. Molecular cloning and differential expression patterns of avian glutamate receptor mRNAs. J. Neurochem. 1995 Jun;64(6):2413-26.

Overton JM, Redding MW, Yancey SL, Stremel RW. Hypothalamic GABAergic influences on treadmill exercise responses in rats. Brain Res Bull. 1994;33(5):51722.

Ozawa S; Kamiya H; Tsuzuki K. Glutamate receptors in the mammalian central nervous system. Prog Neurobiol. 1998 Apr;54(5):581-618.

Paperna T; Lamed Y; Teichberg VI. CDNA cloning of chick brain $\alpha$-amino-3-hydroxy5 methyl-4-isoxazolepropionic acid receptors reveals conservation of structure, function and post-transcriptional processes with mammalian receptors. Mol Brain Res. 1996 Feb;36(1):101-13.

Perestenko P; Ashby MC; Hanley JM. Real-time imaging of alpha-amino-3-hydroxy5-methyl-4-isoxazolepropionic acid receptor (AMPA receptor) movements in neurons. Biochem Soc Trans. 2003 Aug;31(Pt 4):880-4.

Persson AI, Naylor AS, Jonsdottir IH, Nyberg F, Eriksson PS, Thorlin T. Differential regulation of hippocampal progenitor proliferation by opioid receptor antagonists in running and non-running spontaneously hypertensive rats. Eur J Neurosci. 2004 Apr;19(7):1847-55.

Peters S.; Koh J.; Choi D.W. Zinc selectively blocks the action of N-methyl-Daspartate on cortical neurons. Science. 1987 May 1;236(4801):589-593. 
Petralia RS; Wang YX; Wenthold RJ. The NMDA receptor subunits NR2A and NR2B show histological and ultrastructural localization patterns similar to those of NR1. J Neurosci., 1994 Oct;14(10):6102-20.

Petralia RS e Wenthold RJ. Light and electron immunocytochemical localization of AMPA-selective glutamate receptors in the rat brain. J. Comp. Neurol. 1992. 318:329-354.

Philpot BD, Weisberg MP, Ramos MS, Sawtell NB, Tang YP, Tsien JZ, Bear MF. Effect of transgenic overexpression of NR2B on NMDA receptor function and synaptic plasticity in visual cortex. Neuropharmacology. 2001 Nov;41(6):762-770.

Pin, JP; Duvoisin, R. The metabotropic glutamate receptors: structure and functions. Neuropharmacology. 1995; 34(1): 1-26.

Pires RS, Real CC, Hayashi MA, Britto LRG. Ontogeny of subunits 2 and 3 of the AMPA-type glutamate receptors in Purkinje cells of the developing chick cerebellum. Brain Res. 2006 Jun 22;1096(1):11-9.

Pires RS e Britto LRG. Distribution of AMPA-type glutamate receptor subunits in the chick visual system. Braz J Med Biol Res. 1997 Jan;30(1):73-7.

Plant K, Pelkey KA, Bortolotto ZA, Morita D, Terashima A, McBain CJ, Collingridge GL, Isaac JT. Transient incorporation of native GluR2-lacking AMPA receptors during hippocampal long-term potentiation. Nat Neurosci. 2006 May;9(5):602-604.

Poulton NP, Muir GD. Treadmill training ameliorates dopamine loss but not behavioral deficits in hemi-parkinsonian rats. Exp Neurol. 2005 May;193(1):181-97.

Pradelles, P., Grassi, J., Maclouf, J.A. Enzyme immunoassays of eicosanoids using acetylcholinesterase as label: An alternative to radioimmunoassay. Anal Chem. 1985. 57:1170-1173.

Qiu DL, Knöpfel T. An NMDA receptor/nitric oxide cascade in presynaptic parallel fiber-Purkinje neuron long-term potentiation. J Neurosci. 2007 Mar 28;27(13):340815.

Sacchetto R, Cliffer KD, Podini P, Villa A, Christensen BN, Volpe P. Intracellular $\mathrm{Ca} 2+$ stores in chick cerebellum Purkinje neurons: ontogenetic and functional studies. Am J Physiol. 1995. 269:C1219-1227.

Sanes JR, Lichtman JW. Can molecules explain long-term potentiation? Nat Neurosci. 1999 Jul;2(7):597-604.

Schoepp, DD.; Bockaert, J.; Sladeczek, F. Pharmacological and functional characteristics of metabotropic excitatory amino acid receptors. Trends Pharmacol. Sci., 1990; 11: 508-515. 
Scopel D.; Fochesatto C.; Cimarosti H.; Rabbo M.; Bello-Klein A.; Salbego C.; Netto C.A.; Siqueira I.R. Exercise intensity influences cell injury in rat hippocampal slices exposed to oxygen and glucose deprivation. Brain Res Bull. 2006 Dec. 11;71(13):155-159.

Song I, Huganir RL. Regulation of AMPA receptors during synaptic plasticity. Trends Neurosci. 2002 Nov;25(11):578-88.

Soriano E, Frotscher M. A GABAergic axo-axonic cell in the fascia dentata controls the main excitatory hippocampal pathway. Brain Res. 1989 Nov 27;503(1):170-4.

Radak Z, Sasvari M, Nyakas C, Kaneko T, Tahara S, Ohno H, Goto S. Single bout of exercise eliminates the immobilization-induced oxidative stress in rat brain. Neurochem Int. 2001 Jul;39(1):33-8.

Rapp PR, Gallagher M. Preserved neuron number in the hippocampus of aged rats with spatial learning deficits. Proc Natl Acad Sci U S A. 1996 Sep 3;93(18):9926-30.

Redila V.A.; Olson A.K.; Swann S.E.; Mohades G.; Webber A.J.; Weinberg J.; Christie B.R. Hippocampal cell proliferation is reduced following prenatal ethanol exposure but can be rescued with voluntary exercise. Hippocampus. 2006;16(3):305311.

Reidman DA, Maher TJ, Chaiyakul P, Ally A. Modulation of extracellular glutamate and pressor response to muscle contraction during NMDA-receptor blockade in the rostral ventrolateral medulla. Neurosci Res. 2000 Feb;36(2):147-56.

Reiner A; Jiao Y; Del Mar N; Laverghetta AV; Lei WL. Differential morphology of pyramidal-tract type and intratelencephalically-projecting type corticostriatal neurons and their intrastriatal terminals in rats. J Comp Neurol. 2003. 457:420-440.

Ribak CE, Vaughn JE, Barber RP. Immunocytochemical localization of GABAergic neurones at the electron microscopical level. Histochem J. 1981 Jul;13(4):555-82.

Ribak CE, Vaughn JE, Saito K. Immunocytochemical localization of glutamic acid decarboxylase in neuronal somata following colchicine inhibition of axonal transport. Brain Res. 1978 Jan 27;140(2):315-332.

Rispal-Padel L, Meftah EM. Changes in motor responses induced by cerebellar stimulation during classical forelimb flexion conditioning in cat. J Neurophysiol. 1992 Sep;68(3):908-26.

Salgado-Delgado R, Angeles-Castellanos M, Buijs MR, Escobar C. Internal desynchronization in a model of night-work by forced activity in rats. Neuroscience. 2008 Jun; 154(3):922-931.

Santos RV; Caperuto EC; Costa Rosa LF. Effects of acute exhaustive physical exercise upon glutamine metabolism of lymphocytes from trained rats. Life Sci. 2007 Jan 16; 80(6): 573-578. 
Santos NF. Desenvolvimento do modelo de epilepsia induzido por pilocarpina em camundongos. [Dissertação] São Paulo: UNIFESP - Escola Paulista de Medicina, 61 p. 1995. Universidade Federal de São Paulo.

Sarna J.R.; Hawkes R. Patterned Purkinje cell death in the cerebellum. Prog Neurobiol. 2003. 70(6): 473-507.

Sanes JN, Suner S, Donoghue JP. Dynamic organization of primary motor cortex output to target muscles in adult rats. I- Long-term patterns of reorganization following motor or mixed peripheral nerve lesions. Exp. Brain Res. 1990. 79:479-491.

Sato K.; Kiyama H.; Tohyama M. The differential expression patterns of messenger RNAs encoding non-N-methyl-D-aspartate glutamate receptor subunits (GluR1-4) in the rat brain. Neurosci. 52, 515-539.

Sheng M; Hyoung Lee S. AMPA receptor trafficking and synaptic plasticity: major unanswered questions. Neurosci Res. 2003 Jun; 46(2):127-34.

Shors TJ, Thompson RF. Acute stress impairs (or induces) synaptic long-term potentiation (LTP) but does not affect paired-pulse facilitation in the stratum radiatum of rat hippocampus. Synapse. 1992 Jul;11(3):262-5.

Silva LA, Pinho CA, Scarabelot KS, Fraga DB, Volpato AM, Boeck CR, De Souza CT, Streck EL, Pinho RA. Physical exercise increases mitochondrial function and reduces oxidative damage in skeletal muscle. Eur J Appl Physiol. 2009

Smith WB, Starck SR, Roberts RW, Schuman EM. Dopaminergic stimulation of local protein synthesis enhances surface expression of GluR1 and synaptic transmission in hippocampal neurons. Neuron. 2005 Mar 3; 45(5):765-79.

Sommer B, Monyer H, Wisden W, Verdoorn TA, Burnashev N, Sprengel R, Sakmann B, Seeburg PH. Arzneimittelforschung. 1992 Feb;42(2A):209-10.

Sommer B, Keinänen K, Verdoorn TA, Wisden W, Burnashev N, Herb A, Köhler M, Takagi T, Sakmann B, Seeburg PH. Flip and flop: a cell-specific functional switch in glutamate-operated channels of the CNS. Science. 1990 Sep; 49(4976):1580-1585.

Snyder JS, Glover LR, Sanzone KM, Kamhi JF, Cameron HA. The effects of exercise and stress on the survival and maturation of adult-generated granule cells. Hippocampus. 2009 Jan 20.

Southam E, Garthwaite J. Climbing Fibres as a Source of Nitric Oxide in the Cerebellum. Eur J Neurosci. 1991; 3(4):379-382.

Soya H. 2001. Stress response to exercise and its hypothalamic regulation: possible role of arginine-vasopressin. In: Nose, H. Exercise, Nutrition, and Environmental Stress. I.L. Cooper, Traverse City, p. 21-37. 
Sprengel R.; Suchanek B.; Amico C.; Brusa R.; Burnashev N.; Rozov A.; Hvalby O.; Jensen V.; Paulsen O.; Andersen P.; Kim J.J.; Thompson R.F.; Sun W. Webster LC, Grant SG, Eilers J, Konnerth A, Li J, McNamara JO, Seeburg PH. Importance of the intracellular domain of NR2 subunits for NMDA receptor function in vivo. Cell. 1998 Jan 23; 92(2):279-289.

Steinberg JP, Huganir RL, Linden DJ. N-ethylmaleimide-sensitive factor is required for the synaptic incorporation and removal of AMPA receptors during cerebellar longterm depression. Proc Natl Acad Sci U S A. 2004 Dec 28; 101(52):18212-6.

Stranahan A.M.; Khalil D.; Gould E. Running induces widespread structural alterations in the hippocampus and entorhinal cortex. Hippocampus. 2007; 17(11):1017-22.

Stummer W.; Weber K.; Trammer B.; Baethmann A.; Kempski O. Reduced mortality and brain damage after locomotor activity in gerbil forebrain ischemia. Stroke. 1994; 25:1862-1869.

Subramaniam S e McGonigle P. Quantitative autoradiographic characterization of the binding of (+)-5-methyl-10,11-dihydro-5H-dibenzo[a,d]cyclohepten-5, 10-imine $([3 \mathrm{H}] \mathrm{MK}-801)$ in rat brain: regional effects of polyamines. J Pharmacol Exp Ther. 1991, 256(2):811-9.

Sumic A; Michael YL; Carlson NE; Howieson DB; Kaye JA. Physical Activity and the Risk of Dementia in Oldest Old. Journal of Aging e Health. 2007Apr, 19(2): 242-259.

Sutula T, He XX, Cavazos J, Scott G. Synaptic reorganization in the hippocampus induced by abnormal functional activity. Science. 1998; 239:1147-1150.

Tallaksen-Greene SJ, Albin RL. Localization of AMPA-selective excitatory amino acid receptor subunits in identified populations of striatal neurons. Neuroscience. 1994 Aug; 61(3):509-19.

Tallaksen-Greene SJ; Albin RL. Splice variants of glutamate receptor subunits 2 and 3 in striatal projection neurons. Neuroscience. 1996. 75(4):1057-1064.

Tanaka J; Matsuzaki M; Tarusawa E; Momiyama A; Molnar E; Kasai H; Shigemoto R. Number and density of AMPA receptors in single synapses in immature cerebellum. J Neurosci. 2005 Jan 26; 25(4):799-807.

Tanaka H, Grooms SY, Bennett MV, Zukin RS. The AMPAR subunit GluR2: still front and center-stage. Brain Res. 2000 Dec 15; 886(1-2):190-207.

Terashima A, Cotton L, Dev KK, Meyer G, Zaman S, Duprat F, Henley JM, Collingridge GL, Isaac JT. Regulation of synaptic strength and AMPA receptor subunit composition by PICK1. J Neurosci. 2004 Jun 9; 24(23):5381-90. 
Theiss C; Hellmann B; Güntürkün O. The differential distribution of AMPA-receptor subunits in the tectofugal system of the pigeon. Brain Res. 1998 Feb 23; 785(1):11428.

Tillerson JL; Caudle WM; Reveron ME; Miller GW. Exercise induces behavioral recovery and attenuates neurochemical deficits in rodent models of Parkinson's disease. Neuroscience. 2003; 119(3):899-911.

Toledo CA; Britto LR; Pires RS; Reiner A. Interspecific differences in the expression of the AMPA-type glutamate receptors and parvalbumin in the nucleus of EdingerWestphal of chicks and pigeons. Brain Res. 2002 Aug 23; 947(1):122-30.

Tomiyama M, Palacios JM, Cortés R, Mengod G. Flip and flop variants of AMPA receptor subunits in the human cerebellum: implication for the selective vulnerability of Purkinje cells. Synapse. 1999 Feb; 31(2):163-7.

Torres, J.B. A memoria espacial e a atividade hitoquímica da NADPH diaforase no hipocampo, cerebelo e estriado são moduladas por diferentes modalidades de exercício. Tese de mestrado apresentada ao Programa de Pós-graduação em Neurociênias e Bilogia Celular da Univesidade Federal do Pará (UFPA), (2005).

Tóth K, McBain CJ. Afferent-specific innervation of two distinct AMPA receptor subtypes on single hippocampal interneurons. Nat Neurosci. 1998 Nov;1(7):572-8.

Towbin $\mathrm{H}$; Staehelin $\mathrm{T}$; Gordon J. Electrophoretic transfer of proteins from polyacrylamide gels to nitrocellulose sheets: procedure and some applications. Biotechnology. 1992; 24:145-9.

Trombley PQ, Shepherd GM. Differential modulation by zinc and copper of amino acid receptors from rat olfactory bulb neurons. J Neurophysiol. 1996 Oct;76(4):25362546.

Tyler WJ, Pozzo-Miller L. Miniature synaptic transmission and BDNF modulate dendritic spine growth and form in rat CA1 neurones. J Physiol. 2003 Dec 1; 553(Pt 2):497-509.

Uysal N, Tugyan K, Kayatekin BM, Acikgoz O, Bagriyanik HA, Gonenc S, Ozdemir D, Aksu I, Topcu A, Semin I. The effects of regular aerobic exercise in adolescent period on hippocampal neuron density, apoptosis and spatial memory. Neurosci Lett. 2005 Aug 5; 383(3):241-5.

van Groen T, Miettinen P, Kadish I. The entorhinal cortex of the mouse: organization of the projection to the hippocampal formation. Hippocampus, 2003; 13(1):133-49.

van Praag $\mathrm{H}$. Neurogenesis and exercise: past and future directions. Neuromolecular Med. 2008; 10(2):128-40.

van Praag H; Kempermann G; Gage FH. Running increases cell proliferation and neurogenesis in the adult mouse dentate gyrus. Nat Neurosci. 1999 Mar; 2(3):26670. 
van Praag H; Christie BR; Sejnowski TJ; Gage FH. Running enhances neurogenesis, learning, and long-term potentiation in mice. Proc Natl Acad Sci U S A. 1999 Nov 9; 96(23):13427-31.

Vaynman S, Ying Z, Gomez-Pinilla F. Exercise induces BDNF and synapsin I to specific hippocampal subfields. J Neurosci Res. 2004a May; 76(3):356-62.

Vaynman S, Ying Z, Gomez-Pinilla F. Hippocampal BDNF mediates the efficacy of exercise on synaptic plasticity and cognition. Eur J Neurosci. 2004b Nov; 20(10):2580-90.

Vaynman S.; Ying Z.; Gomez-Pinilla F. Interplay between brain-derived neurotrophic factor and signal transduction modulators in the regulation of the effects of exercise on synaptic-plasticity. Neuroscience. 2003; 122(3):647-57.

Vissing J, Andersen M, Diemer NH. Exercise-induced changes in local cerebral glucose utilization in the rat. J Cereb Blood Flow Metab. 1996 Jul; 16(4):729-36.

Vorobjev VS.; Sharonova IN; Haas HL; Sergeeva OA. Differential modulation of AMPA receptors by cyclothiazide in two types of striatal neurons. Eur. J. Neurosci. 2000. 12:2871-2880.

Vrba R. Significance of glutamic acid in metabolic processes in the rat brain during physical exercise. Nature. 1955 Dec 31; 176(4496):1258-61.

Walker MC, Ruiz A, Kullmann DM. Do mossy fibers release GABA? Epilepsia. 2002; 43 Suppl 5:196-202.

Wang RY, Yang YR, Yu SM. Protective effects of treadmill training on infarction in rats. Brain Res. 2001 Dec 13; 922(1):140-143.

Watkins JC e Jane DE. The glutamate story British Journal of Pharmacology. 2006 Aug 23; 947(1):122-30.

Williams CA, Gopalan R, Nichols PL, Brien PL. Fatiguing isometric contraction of hind-limb muscles results in the release of immunoreactive neurokinins from sites in the rostral medulla in the anesthetized cat. Neuropeptides. 1995 Apr; 28(4):209-18.

West MJ, Slomianka L, Gundersen HJ. Unbiased stereological estimation of the total number of neurons in thesubdivisions of the rat hippocampus using the optical fractionator. Anat Rec. 1991 Dec; 231(4):482-97.

Westphal R.S.; Tavalin S.J.; Lin J.W.; Alto N.M.; Fraser I.D.; Langeberg L.K.; Sheng M.; Scott J.D. Regulation of NMDA receptors by an associated phosphatase-kinase signaling complex. Science. 1999 Jul 2;285(5424):93-96.

Wheeler D; Boutelle MG; Fillenz M. The role of $N$-methyl-D-aspartate receptors in the regulation of physiologically released dopamine. Neuroscience. 1995. 65:767-774. 
Wiberg M, Blomqvist A. Input from muscle and cutaneous nerves of the hand and forearm to neurones of the precentral gyrus of boons and monkeys. J. Physiol (Lond), 1973; 228:203-219.

Witter MP, Amaral DG. Entorhinal cortex of the monkey: V. Projections to the dentate gyrus, hippocampus, and subicular complex. J Comp Neurol. 1991 May 15;307(3):437-59.

Wollmuth L.P.; Kuner T.; Sakmann B. Intracellular Mg2+ interacts with structural determinants of the narrow constriction contributed by the NR1-subunit in the NMDA receptor channel. J Physiol. 1998 Jan 1;506 ( Pt 1):33-52.

Wright AK, Ramanathan S, Arbuthnott GW. Identification of the source of the bilateral projection system from cortex to somatosensory neostriatum and an exploration of its physiological actions. Neuroscience. 2001;103(1):87-96.

Yaka R, Salomon S, Matzner H, Weinstock M. Effect of varied gestational stress on acquisition of spatial memory, hippocampal LTP and synaptic proteins in juvenile male rats. Behav Brain Res. 2007 Apr 16;179(1):126-32.

Yamada K.; Watanabe M. Cytodifferentiation of Bergmann glia and its relationship with Purkinje cells. Anat Sci Int. 2002; 77(2):94-108.

Ying Z, Roy RR, Edgerton VR, Gomez-Pinilla F. Exercise restores levels of neurotrophins and synaptic plasticity following spinal cord injury. Exp Neurol. 2005 Jun;193(2):411-9.

Zafra F, Castrén E, Thoenen H, Lindholm D. Interplay between glutamate and gamma-aminobutyric acid transmitter systems in the physiological regulation of brainderived neurotrophic factor and nerve growth factor synthesis in hippocampal neurons. Proc Natl Acad Sci U S A. 1991 Nov 15;88(22):10037-41. 